\title{
Federal Habeas Corpus and Ineffective Representation of Counsel: The Supreme Court Has Work To Do
}

\author{
Peter W. Tague \\ Georgetown University Law Center, tague@law.georgetown.edu
}

This paper can be downloaded free of charge from:

https://scholarship.law.georgetown.edu/facpub/706

31 Stan. L. Rev. 1-67 (1978)

This open-access article is brought to you by the Georgetown Law Library. Posted with permission of the author. Follow this and additional works at: https://scholarship.law.georgetown.edu/facpub

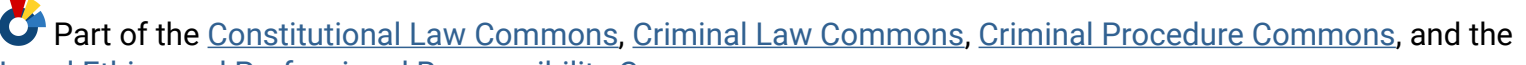
Legal Ethics and Professional Responsibility Commons 


\title{
Federal Habeas Corpus and Ineffective Representation of Counsel: The Supreme Court Has Work To Do
}

\author{
Peter W. Tague*
}

The availability of federal habeas corpus relief for state criminal defendants has always borne a complex relationship to state rules barring defendants from litigating constitutional claims in state court because of procedural defaults in raising those claims. ${ }^{1}$ The Warren Court's landmark attempt to resolve this relationship was the 1963 decision in Fay v. Noia, ${ }^{2}$ which asserted that a state procedural forfeiture rule could not bar federal habeas review of a constitutional claim unless the defendant had "deliberately bypassed" the procedural opportunity to raise the claim; ${ }^{3}$ the Court defined "deliberate bypass" in terms of a defendant's intentional and voluntary relin-

* A.B. 1965, Harvard College; J.D. 1969, University of Michigan Law School. Associate Professor of Law, Georgetown University Law Center. Member of the bars of California, New York, and Washington, D.C.

1. Though it concentrates on the availability of federal habeas relief for a state defendant who violates a state procedural rule governing the timing of objections, the discussion in this article also generally applies to the availability of federal habeas under 28 U.S.C. $§ 2255$ (1970) for the federally convicted defendant who violates the timing requirements of FED. $R$. CRIM. P. 12.

2. 372 U.S. 391 (1963). For a brief survey of the inconsistent treatment of this problem by the federal courts before 1963, see $i d$ at $414-26$.

3. Id. at 438-39. The petitioner, Noia, serving a life sentence for felony murder, had chosen not to appeal directly his claim that the prosecution had coerced his confession in violation of the fifth amendment. But the Fay Court held that Noia's decision not to appeal was not a "deliberate bypass," because he had faced a "grisly choice" between a prison sentence and the risk of a death sentence on retrial. Id. at 439-40.

Fay recognized that the states had a legitimate interest in "exacting compliance with their procedural rules," id. at 431 , but it held that this interest was sufficiently vindicated by the defendant's loss of any right to direct or collateral review in the state courts and direct review by the United States Supreme Court. Id. at 433 .

(A stylistic point: This article uses the terms "defendant" and "petitioner" interchangeably to refer to the defendant who petitions for federal habeas corpus review, the choice determined by clarity within context.) 
quishment of a known right. ${ }^{4}$ Even when, 2 years later, in Henry $v$. Mississippi ${ }^{5}$ the Warren Court ruled that state procedural defaults could bar post-conviction state review ${ }^{6}$ as well as direct Supreme Court review of a federal claim, ${ }^{7}$ it left open the Fay avenue to federal habeas relief. ${ }^{8}$

But the Warren Court left several crucial questions unresolved for lower courts. Did the defendant or the attorney control the defense case for the purposes of habeas law? ${ }^{9}$ If counsel's decision not to raise a constitutional claim by objecting at trial could eliminate the defendant's right to get all state post-conviction review and direct review by the Court, could that decision also ever eliminate the defendant's right to federal habeas review of the claim ${ }^{10}$ If so, were there nonetheless certain federal rights that only the defendant could waive before federal habeas review would be barred? If counsel's decision could bind the client, what sort of decision did counsel have to make? Could the attorney's decision not to object to a constitutional infringement bind the client even if the attorney had failed to research the relevant law, or investigate the facts, or appreciate the relationship of the law to the facts? ${ }^{11}$ Could the defense counsel bind the defendant if the counsel did not even know an objection was

4. Id. at 439 (citing Johnson v. Zerbst, 304 U.S. 458, 464 (1938)).

5. 379 U.S. 443 (1965).

6. Id. at 447. Whether the purpose of the state's procedural rule is legitimate remained a federal constitutional question. Id. at 447-48. The Court also reserved the right to determine whether the legitimate state interest was satisfied by counsel's conduct even if such conduct did not technically comply with the rule. See id. at 448-49 (attorney's motion for directed verdict satisfied state's interest in timely decision of motions to suppress evidence).

7. Id. at $450-51$.

8. See id. at 452 . On subsequent habeas review, the federal district court, after finding that neither Henry nor his counsel had deliberately bypassed the opportunity to raise the fourth amendment issue, reversed the conviction on its merits. Henry v. Williams, $299 \mathrm{~F}$. Supp. 36 (N.D. Miss. 1969).

9. Some post-Fay courts applied a very fluid standard to this problem, examining the "stage of the proceedings at which the decision is made, the significance of the legal consequences which attach to the decision, the practical necessities of the adversary system, the degree to which counsel has an adequate opportunity to consult with the client before the decision is made, and the degree to which society has entrusted counsel to make independent judgments in his role as an advocate." United States $e x$ rel. Brown v. Warden, 417 F. Supp. 970, 973 (N.D. Ill. 1976). Others held that Henry empowered counsel to make every decision unless the defendant could show "exceptional circumstances" to justify application of Fay. E.g., Winters v. Cook, 489 F.2d 174, 177 (5th Cir. 1973).

10. Henry's discussion of whether only the defendant's waiver of the opportunity to object could bar federal habeas is unclear. See 379 U.S. at 450-52. Some lower courts interpreted Henry to mean that counsel's deliberate bypass could bar federal habeas. Compare Nelson v. California, 346 F.2d 73, 81 (9th Cir. 1965) (yes), with Henry v. Williams, 299 F. Supp. 36 (N.D. Miss. 1969) (no). For a discussion of Henty's ambiguities, see Hill, The Inadequale State Ground, 65 CoLuM. L. REV. 943, 980-92 (1965).

11. Compare Kuhl v. United States, 370 F.2d 20 (9th Cir. 1966) (deliberate bypass where 
possible? Could the defendant challenge the competency of the counsel's decision, even if that decision barred all review of the merits of the issue counsel did not raise? ${ }^{12}$ Which side-the defense or the government-had the burdens of production and persuasion on deliberate bypass? ${ }^{13}$

Federal courts struggled with these questions, ${ }^{14}$ and answered them in different ways. The differences in approach resulted in part from the different ways in which the courts treated a record that did not clearly reveal why the defense had not objected. Although the federal appellate courts occasionally remanded to the district court to develop that information, ${ }^{15}$ they usually reviewed the record in an attempt to infer the attorney's trial strategy. If counsel's failure to object was consistent with his apparent trial strategy-if the attorney had, for example, affirmatively used the very evidence at trial that, on collateral attack, the defendant claimed the government should not have used-some appellate courts found deliberate bypass. ${ }^{16}$ Other appellate courts found deliberate bypass by speculating that

counsel mistaken as to standing to raise legal issue), with Pineda v. Craven, 424 F.2d 369 (9th Cir. 1970) (no deliberate bypass where counsel unaware of controlling precedent).

12. Most courts found no ineffective representation where counsel overlooked only one constitutional objection. See, e.g., People v. Washington, 41 Ill. 2d 16, 241 N.E.2d 425 (1968).

13. See notes 180-87 infra and accompanying text.

14. See, e.g., United States ex rel. Brown v. Warden, 417 F. Supp. 970, 972 (N.D. Ill. 1976) (noting "ambiguity" in Fay test of deliberate bypass). The ever-increasing scholarly criticism of Fay and Henry by judges magnified the problem of interpreting the decisions. See Burger, The State of the Judician-1970, 56 A.B.A.J. 929, 931 (1970); Friendly, Is Innocence Irrelevant? Collateral Altack on Criminal Judgments, 38 U. CHI. L. REv. 142, 170-71 (1970); Gibbons, Waiver: The Quest for Functional Limitations on Habeas Corpus Jurisdiction, 2 SETON HALL L. REV. 291 (1971); Haynsworth, Improving the Handling of Criminal Cases in the Federal Appellate System, 59 CORNELl L. REV. 597, 601-04 (1974).

15. See, e.g., Johns v. Perini, 440 F.2d 577 (6th Gir. 1972) (remand to determine whether counsel had tactically decided not to give notice of alibi); $f$. United States v. Greer, 538 F.2d 437, 441 n.11 (D.C. Cir. 1976) (urging that evidentiary hearing always be held to determine whether attorney failed to act for tactical reasons).

16. See United States $e x$ rel. Terry v. Henderson, 462 F.2d 1125, 1128-29 (2d Cir. 1972) (deliberate bypass where counsel did not object to confession and used it to win acquittal on one count); United States ex rel. Cruz v. LaVallee, 448 F.2d 671 (2d Cir. 1971), cert. denied, 406 U.S. 958 (1972) (deliberate bypass where counsel did not object to confession but used it to show mitigating circumstances); of. Winters v. Cook, 489 F.2d 174 (5th Cir. 1973) (deliberate bypass where counsel chose not to object to grand jury so as to negotiate a favorable plea bargain). Where an attorney raised the issue of potential prejudice but did not object, some courts held the defendant to have bypassed the opportunity to object. See, e.g., Rodriguez v. Estelle, 536 F.2d 1096 (5th Cir. 1976) (counsel's failure to move for mistrial or otherwise object to two jurors having read news account of defendant's 1,500-year sentence in another case, after counsel himself had raised issue before trial court, held a deliberate bypass). But the Supreme Court itself held in Henry that counsel's mere attempt to rebut evidence to which no timely objection had been made did not in itself comprise bypass. 379 U.S. at 446. 
the attorney might have believed that the objection would fail. ${ }^{17}$ Still other courts found no deliberate bypass if they could discern no tactical purpose served by the failure to object. ${ }^{18}$ And some courts simply avoided the question without considering whether the attorney had deliberately bypassed the opportunity to object. ${ }^{19}$

These differences among the federal habeas courts made it important for the Supreme Court to define deliberate bypass further if the Court wanted that test to serve as a fair and effective limit on federal habeas relief. Three recent cases, Estelle v. Williams, ${ }^{20}$ Francis $v$. Henderson, ${ }^{21}$ and Wainwright v. Sykes, ${ }^{22}$ presented the Burger Court with opportunities to do so. But, rather than clarify the deliberate bypass test, the Court used these opportunities to replace it with an entirely new, unnecessarily obscure, and far more restrictive test: requiring habeas petitioners to show "cause" for and "prejudice" resulting from their procedural failure in raising federal claims in state court. ${ }^{23}$

Estelle, Francis, and Sykes reflect the Burger Court's assiduous effort to restrict the availability of federal habeas corpus relief. ${ }^{24}$

17. See Whitney v. United States, 513 F.2d 326, 329 (8th Cir. 1974) (suppression motion); United States ex rel. Broaddus v. Rundle, 429 F.2d 791, 795 (3d Cir. 1970) (admissibility of confession); ff. United States ex rel. Brown v. Warden, 417 F. Supp. 970 (N.D. Ill. 1976) (bypass found where counsel admits he failed to make objection because he thought it was frivolous).

18. See, e.g., Minor v. Black, 527 F.2d 1 (6th Cir. 1975) (no deliberate bypass where nothing in record indicated why counsel had not objected to admission of and government's comment on evidence of defendant's pretrial silence used for impeachment purpose).

19. See Setz v. Galifornia, 423 F.2d 704 (9th Cir. 1970); of. United States v. Blitz, 533 F.2d 1329 (2d Gir. 1976) (grand jury attack waived under FED. R. CRIM. P. 12, but court decides merits); United States v. Maretti, 323 F. Supp. 683 (D. Del. 1971) (court reaches merits after deciding no cause shown to excuse failure to follow time provisions of FED. $R$. Crim. P. 12; ABA Project on Minimum Standards for Criminal Justice, Standards Relating to Post-Conviction Remedies § 2.1, at 36 \& Comm. § 6.1(a) (App. Draft 1968) [hereinafter cited as ABA POST-CONVICTION REMEDIES] (habeas court should deny petition, if unmeritorious, rather than decide issue of deliberate bypass); Friendly, supra note 14, at 158-59. Courts have usually used this approach in denying the petition either because its allegations lacked merit or because the alleged constitutional error was harmless.

20. 425 U.S. 501 (1976).

21. 425 U.S. 536 (1976).

22. 433 U.S. 72 (1977).

23. See id. at 87 . In creating this test, the Court never explained why further development of the bypass restriction would not have achieved the Court's perceived goals. The Warren Court itself, perhaps realizing that $F_{a y}$ could have allowed reversal on federal habeas of every conviction where a constitutional violation had occurred, may have developed the doctrines of retroactivity, see Linkletter v. Walker, 381 U.S. 618 (1965), and harmless error, see Chapman v. California, 386 U.S. 18 (1967), in order to develop controls on the impact of Fay.

24. Earlier Burger Court decisions restricting federal habeas review on grounds of petitioners' waiver or forfeiture include Tollett v. Henderson, 411 U.S. 258 (1973) (guilty plea 
Though recent commentary ${ }^{25}$ has focused on the severe limitations placed on habeas relief by the Court's decision in Stone v. Powell, ${ }^{26}$ which all but eliminated federal habeas review of state court decisions on fourth amendment claims, Estelle, Francis, and Sykes will probably restrict federal habeas relief far more. But these new decisions may ultimately fail to achieve the Court's goals of reducing the federal habeas workload and alleviating friction between state and federal courts, since the new cases may invite state criminal defendants to transform their constitutional claims into attacks on their attorneys' competency for having failed to raise those claims, and thereby find a new and still open, if somewhat circuitous, route to the federal courts.

This article examines the complex effects of Estelle, Francis, and Sykes. Part I traces the emergence in those cases of the new "cause and prejudice" rule. Part II explains the criteria by which the courts will probably apply it. Part III criticizes the new rule for unnecessarily restricting access to federal habeas review while failing to fulfill

waives review of constitutional claims on matters antedating plea); Davis v. United States, 411 U.S. 233 (1973) (failure to raise timely claim of illegal grand jury waived under FED. R. CRIM. P. 12(b)(2)); McMann v. Richardson, 397 U.S. 759 (1970) (habeas review of allegedly coerced confession waived by guilty plea); of. Swain v. Pressley, 430 U.S. 372 (1977) (holding constitutional District of Columbia statute barring habeas petition to federal district courts for defendants failing to move for collateral relief under special statutory alternative). But see Lefkowitz v. Newsome, 420 U.S. 283 (1975) (state law allowing state post-conviction review of claims arising before guilty plea does not bar federal habeas review of those claims).

The Burger Court has restricted federal habeas relief in a way that Congress has not chosen to do. Recent legislative proposals to limit federal habeas jurisdiction have failed. See, e.g., S. 567, 93d Cong., 1st Sess. (1973); H.R. 13,722, 92d Cong., 2d Sess. (1972); 123 CoNG. REC. S6025-41 (daily ed. Apr. 20, 1977) (statement by Senators Nelson and Mathias on proposed legislative restrictions); Note, Proposed Modification of Federal Habeas Corpus for State Prisoners-Reform or Revocation?, 61 GEO. L.J. 1221 (1973) (criticizing proposed legislation).

The Burger Court's restrictions were no surprise. Justice Rehnquist, who wrote the Court's opinions in Sykes and in Davis v. United States, 411 U.S. 233 (1973), see notes 68-70 infra and accompanying text, testified, while still an Assistant Attorney General, that Congress should restrict federal habeas jurisdiction in much the way that the Court did in Sykes. See Hearings on S. 895 Before the Subcomm, on Constitutional Rights of the Senate Judiciany Comm., 92d Cong., 1st Sess. 93-121 (1971) [hereinafter cited as Rehnguist Testimony].

25. See, e.g., Flagg, Stone v. Powell and the New Federalism: A Challenge to Congress, 14 Harv. J. Legis. 152, 162-63 (1976); Green, Stone v. Powell: The Hermeneutics of the Burger Court, 10 CREIGHTON L. REV. 655 (1977); Robbins \& Sanders, Judicial Integrity, The Appearance of Justice, And The Great Writ of Habeas Corpus: How To Kill Two Thirds (Or More) With One Stone, 15 AM. Crim. L. Rev. 63 (1977); Note, A Modest Proposal: Habeas Corputs, the Exclusionary Rule and the Supreme Court, 7 MEM. ST. L. REv. 85 (1976).

26. 428 U.S. 465 (1976) (denying habeas review of fourth amendment claim that petitioner had full and fair opportunity to litigate in state court, because claim does not go to issue of guilt or innocence; deterrent value of exclusionary rule outweighed by social cost of extending rule to habeas review). 
or actually undermining some of the Court's primary goals in creating the "cause and prejudice" test. Part IV explains how federal habeas petitioners may now exploit the Court's unintended invitation to petition for relief on grounds of the incompetency of their attorneys in failing to meet state procedural rules, and suggests the work the Court must do if it intends to close off the loophole left open in these decisions.

\section{The Emergence of the "Gause and Prejudice" Rule}

\section{A. Estelle v. Williams}

The evisceration of Fay $v$. Noia in favor of a new restrictive barrier to federal habeas relief was heralded, ironically, by a case in which the majority of the Court never even addressed the question of habeas corpus. Estelle $v$. Williams ${ }^{27}$ resolved the issue of the failure of a defendant and his counsel to raise a constitutional claim at trial by treating that failure, in effect, as negating the very existence of the defendant's claim. Of the majority, only Justice Powell even recognized the issue of waiver or procedural forfeiture of a substantive claim. ${ }^{28}$ And only Justice Brennan's dissent recognized that the Court was retrenching its decision in Fay to allow federal habeas review to defendants whose failure to object does not amount to a deliberate bypass. ${ }^{29}$

A Texas jury convicted Harry Lee Williams of assault with intent to commit murder with malice. ${ }^{30}$ Before the trial began, Williams' jailor had denied the defendant's request to change into civilian clothes. $^{31}$ Neither Williams nor his attorney objected to the trial judge that Williams' appearance in jail dress might prejudice the jury. But, in contrast to Louisiana and Florida, whose procedural default statutes played a major role in Francis $v$. Henderson and Wainwright $v$. Sykes, ${ }^{32}$ Texas apparently had no contemporaneous objection rule that barred appellate review of an issue not raised at trial. ${ }^{33}$

27. 425 U.S. 501 (1976).

28. Id. at 513-15 (Powell, J., concurring).

29. Id. at 523-35 (Brennan, J., dissenting).

30. Id. at 502 .

31. Id. at 502. No issue was made of the possibility that the defendant's request to his jailor had put the state-and thus the trial court-on notice of the defendant's fear of jury prejudice.

32. See notes $67 \& 83$ infra and accompanying text.

33. The Texas appellate court mentions no such rule. See Williams v. State, 477 S.W.2d 24 (Tex. Crim. App. 1972). In any event, because that court decided the merits of the jail clothes issue even though the defendant had not objected, the issue could be relitigated on federal habeas under Brown v. Allen, 344 U.S. 443, 460-65 (1953). 
On direct appeal, the Texas courts affirmed the conviction. ${ }^{34}$ On federal collateral attack, Williams claimed that his counsel had been constitutionally ineffective and that his jail dress had violated his due process right to a fair trial. ${ }^{35}$ During an evidentiary hearing on habeas review in the federal court, Williams and his attorney both testified that they had not wanted the defendant to wear jail clothes and had feared that the clothes might prejudice the jury. ${ }^{36}$ Counsel had not objected at trial because he had thought it futile to do so; he believed that the practice of the trial judge and other judges in that district was to have non-bailed defendants tried in jail clothes. ${ }^{37} \mathrm{He}$ was wrong: In an affidavit submitted to the habeas court, the trial judge said he would have let Williams change into civilian clothes if only he had asked. ${ }^{38}$ The attorney also did not know that the Fifth Circuit Court of Appeals had earlier held that an appearance by the defendant in jail clothes was inherently prejudicial. ${ }^{39}$ The federal district court concluded that neither Williams nor his attorney had deliberately bypassed the opportunity to object, ${ }^{40}$ a point apparently conceded by the state in the habeas proceeding. ${ }^{41}$ But the district court denied the petition on its merits. Rather than focusing on the failure to object to the jail clothes, the court considered defense counsel's overall performance and concluded that he had not been ineffective. ${ }^{42}$ The district court also held that although Williams' appearance in jail clothes was inherently prejudicial, it was harmless

34. Williams v. State, 477 S.W.2d 24 (Tex. Crim. App. 1972). In his direct appeal, Williams argued that his appearance in jail clothes had violated due process, $i d$. at 26 , that his attorney had been ineffective, id. at 27 , and that the trial court should have instructed on selfdefense, $i d$ at 25 . The Texas appeals court interpreted Williams' failure to object as a choice to go to trial in jail clothes. Id. at 26. Moreover, the court refused to review the self-defense instruction, because counsel had not objected at trial, and concluded that counsel's overall performance had not made the trial "a farce." Id. at 27. The court did not discuss whether counsel's specific failure to object to the jail clothes constituted ineffective representation. Although the court noted that counsel had cross-examined the government's witnesses, id. at 27 , Williams' appellate counsel indicated that trial counsel had conducted virtually no crossexamination, perhaps because there was a dispute over the fee. Interview with appellate counsel (Mar. 18, 1977).

35. Williams v. Beto, 364 F. Supp. 335, 336, 339 (S.D. Tex. 1973).

36. Petitioner's Appendix to the Supreme Court at 47, 58, 73, 74.

37. Williams v. Beto, 364 F. Supp. 335, 338 (S.D. Tex. 1973).

38. Id. at 338.

39. Brooks v. Texas, 381 F.2d 619 (5th Cir. 1967).

40. The district court found that the defense had not committed a deliberate bypass because the trial judge's willingness to permit defendants to wear civilian clothes was neither publicly known nor known by the defense. Williams v. Beto, 364 F. Supp. 335, 343 (S.D. Tex. 1973).

41. Petitioner's Appendix to the Supreme Court at 38.

42. Williams v. Beto, 364 F. Supp. 335, 339 (S.D. Tex. 1973). 
error. ${ }^{43}$

The Fifth Circuit Court of Appeals agreed with the district court that the defense had not deliberately bypassed the opportunity to object, explaining that jail clothes were customarily worn in that judicial district-so that counsel might have assumed that an objection would have been overruled-and finding no evidence that counsel's failure to object was tactically motivated. ${ }^{44}$ The court of appeals reversed, however, disagreeing with the district court's finding that the error involving the jail dress was harmless, since the defendant's appearance might have dissuaded the jury from convicting him of a lesser offense. ${ }^{45}$

The Supreme Court reinstated the conviction in an enigmatic decision. Writing for the majority, Chief Justice Burger incorporated the defense's failure to object to the claimed due process violation into a reinterpretation of the due process right, and thereby denied that the violation had ever occurred: Because the right to appear in civilian clothes is a "trial-type"46 right rather than a "fundamental" right, the right is not violated unless the trial court "compels" the defendant to wear jail clothes. ${ }^{47}$ The Court apparently thought that

43. Id. at 344 .

44. Williams v. Estelle, 500 F.2d 206, 208 (5th Cir. 1974).

45. Id. at $210-12$.

46. The term is Justice Powell's. Estelle v. Williams, 425 U.S. 501, 514 (1976) (Powell, J., concurring). The Chief Justice spoke of rights involving "strategic and tactical" decisions by the defense, distinguishing them from a decision involving the right to counsel. Id. at 512 .

47. Id. at 507. The Court interpreted the Fifth Circuit's decisions as requiring a defense objection to the jail clothes to trigger a due process violation. Although the question is not free from doubt, that interpretation is probably wrong. In Hernandez v. Beto, 443 F.2d 634 (5th Cir. 1971), the Fifth Circuit reversed petitioner's state conviction even though neither Hernandez nor his counsel had requested permission for civilian clothes and despite the fact that counsel had raised no objection at trial. Though Hernandez, like Williams, was only being held in jail awaiting trial, his counsel did not raise an objection to the jail clothing, because he believed from past experience that such a motion would have been denied as frivolous. Id. at 636 . In United States ex rel. Stahl v. Henderson, 472 F.2d 556 (5th Cir.), cert. denied, 411 U.S. 971 (1972), the Fifth Circuit did characterize Hernandez as saying that the defense must object at the trial to the wearing of the jail clothes. Id. at 557 . It then added, however, that in Hemandez the defendant had met this burden. Id. This is a curious interpretation of Hemandez, given the fact that no objection was raised at the trial level. The court seems to have implied that the failure to object is not, in every instance, to be equated with a deliberate choice by the defendant. In Hemandez, the court stated that, given the reason for the attorney's failure to object, the circumstances could not justify inferring a voluntary waiver by the defendant. Hernandez v. Beto, 443 F.2d 634, 637 (5th Cir. 1971). In contrast, a Texas state court presumed in the absence of any explanation that Williams had deliberately decided not to object. Williams v. State, 477 S.W.2d 24, 26-27 (Tex. Crim. App. 1972).

The Fifth Circuit was impressed by the fact that Hernandez was being held in jail awaiting trial. It considered this proof that his jail clothes had prejudiced him at trial. In Stahl, however, petitioner was already a prison inmate both at the time that he allegedly committed the new crime and when he stood trial for that crime. The court of appeals therefore found 
the trial judge would have "compelled" the defendant only by overruling an objection.

Had the Court stopped with this syllogism, Estelle might have had little impact on the availability of federal habeas review, applying only to the substantive question of a defendant's right to wear civilian clothes. ${ }^{48}$ But, in a footnote, ${ }^{49}$ the Court went on to speak in terms that could work a broad restriction on federal habeas review for defendants failing to raise constitutional claims at trial, even if the state has no contemporaneous objection rule. In this footnote, the Court appeared to link the new distinction between fundamental and trial-type rights to the distinction between counseled and uncounseled decisions. If the decision not to object could involve a tactical choice, the right at issue is not fundamental; a decision is tactical-and the underlying right thus nonfundamental-if it is made with the benefit of counsel, because only counsel can be expected to recognize the tactical consequences of failing to object. ${ }^{50}$

no prejudice, since the prison clothes could only reveal to the jury facts it already knew from the evidence at trial. United States $e x$ rel. Stahl v. Henderson, 472 F.2d at 557.

The Fifth Circuit's position on this issue is not easily summarized, since the court "paints with a broad brush these types of cases. Each case must be considered in its own factual context." 443 F.2d at 637 . But, given Hemandez, one cannot conclude as confidently as did the Supreme Court in Estelle that the Fifth Circuit has uniformly required that an objection to jail clothes be lodged.

48. See Haggard v. Alabama, 550 F.2d 1019 (5th Cir. 1977) (absent objection, Estelle bars federal habeas review of defendant's appearance before jury in handcuffs).

49. 425 U.S. at 508 n.3.

50. The actual language of footnote 3 states: "We are not confronted with an alleged relinquishment of a fundamental right of the sort at issue in Johnson $v$. Zerbst . . . There, the Court understandably found it difficult to conceive of an accused making a knowing decision to forgo the fundamental right to the assistance of counsel, absent a showing of conscious surrender of a known right. The Court has not, however, engaged in this exacting analysis with respect to strategic and tactical decisions, even those with constitutional implications, by a counseled accused. . . . The reason for this rule is clear: if the defendant has an objection, there is an obligation to call the matter to the court's attention so the trial judge will have an opportunity to remedy the situation." 425 U.S. at 508 n.3 (citations omitted).

Footnote 3 of the Estelle opinion thus links the bar to availability of federal habeas review to the involvement of counsel in the original failure to object. The distinction between counseled and uncounseled defendants is clearer in Chief Justice Burger's concurring opinion in Wainwright v. Sykes. There, he noted that the Fay deliberate bypass test was never intended to apply to all constitutional errors that occur during the trial process. Wainwright v. Sykes, 433 U.S. 72, 92 (1977) (Burger, C.J., concurring). He distinguished Sykes from Johnson v. Zerbst, 304 U.S. 458 (1938) (involving alleged waiver of right to counsel), and Fay because in the latter cases only the defendant could make the decision to preserve the constitutional claim. Wainwright v. Sykes, 433 U.S. 72, 92 (1977) (Burger, C.J., concurring). The Chief Justice did not say why only the defendant could make the Johnson/Fay-type decisions, but the explanation appears to be practical: An appointed attorney's appointment ends with the verdict or, if the client chooses to appeal, with noticing the appeal and obtaining permission for the defendant to proceed in forma pauperis. The appellate court then appoints an attor- 
Under this view, counsel's failure to object or to make a motion on a particular point will bind the defendant and bar habeas review of the issue. ${ }^{51}$ Although other interpretations of the key footnote in Estelle are possible, ${ }^{52}$ this is the most plausible; it explains Chief Justice Burger's observation that, in a purportedly hopeless case like Williams', counsel may try to elicit jury sympathy for his client by

ney (sometimes the trial attorney, sometimes a new attorney) for the appeal. Retained attorneys also usually contract only to represent the defendant through trial and notice of appeal. As a result, no one but the defendant can decide to appeal or to ask for an attorney for trial or appeal. See Bonds v. Wainwright, 564 F.2d 1125, 1133 n.3 (5th Cir. 1977) (Tjoflat, J., dissenting).

51. If counsel's objection could have prevented the error, the client will be barred from collateral attack. See Henderson v. Kibbe, 431 U.S. 145, 157 (1977) (Burger, C.J., concurring) (failure to object to jury instruction bars collateral attack whether counsel's failure was deliberate or inadvertent).

Under this interpretation of Estelle, the Chief Justice has "answered" the questions, left open by Fay and Henry, of who controls the defense case: Counsel can make every decision; if counsel decides not to object or to make some motion, that decision bars all collateral relief in the federal courts for the defendant, whether or not counsel consulted with the defendant. See Henderson v. Kibbe, 431 U.S. 145, 158 (1977) (Burger, G.J., concurring). If carried to its logical extreme, this interpretation of Estelle would work an even broader restriction on federal habeas review than the "cause and prejudice" test of Francis and Sykes, see Part II infra, by eliminating the Fay deliberate bypass rule even where the failure to object violated no state procedural rule.

52. There are at least two other interpretations of this footnote, each of which would suggest a limitation on the availability of federal habeas relief. First, the Court may have applied Fay and concluded that Williams had deliberately bypassed the opportunity to object because he thought his case hopeless and purposefully wore jail clothes in a desperate attempt to win jury sympathy. See 425 U.S. at 510 n.5 (discussing whether counsel could have made a tactical choice, without so holding). But if this interpretation is correct, the Court not only disagreed with both lower federal courts, but also either ignored or misinterpreted the record from the state habeas hearing. The only evidence of the attorney's purpose in that record was his testimony that he had not objected because he thought an objection futile. Petitioner's Appendix to the Supreme Court at 79. And rather than fearing his case was hopeless, the defendant stated that he thought he had acted in self-defense, $i d$. at 77-79, and that he had chosen not to testify to avoid disclosing a 17-year old conviction, id. at 79. Moreover, the Court would have been underestimating the strength of the defense case, since the court of appeals had not, after all, found harmless error. See text accompanying note 45 supra. The self-defense evidence might have proved even stronger had not the attorney failed both to cross-examine the state's witnesses vigorously, see note 34 supra, and to subpoena a defense witness who would have supported the self-defense theory. (Estelle would not be the first case in which the Court has been accused of misinterpreting the record to support its decision. See Dershowitz \& Ely, Harris v. New York: Some Anxious Observations on the Candor and Logic of the Emerging Nixon Majority, 80 YaLE L.J. 1198, 1199, 1201-09 (1971).

A second possible interpretation is that Estelle is a sweeping redefinition of criminal procedural constitutional rights in general-making a defense objection an element of every right. But this view is highly unlikely because, with the exception of certain elements of the fourth amendment, see Schneckloth v. Bustamonte, 412 U.S. 218 (1973) (suspect need not be informed that he can refuse consent search), and the fifth amendment, see United States v. Washington, 431 U.S. 181, 186-90 (1977) (grand jury witness must invoke fifth amendment protection), the Court has never required a lower court objection to trigger a constitutional violation. 
deliberately allowing him to appear in jail clothes, ${ }^{53}$ and finds support in Justice Powell's assertion that even if a defendant suffers a constitutional violation, there should be no habeas review where the defendant had "consensually relinquished" the right in question or had committed an "inexcusable procedural default" in failing to object. $^{54}$

53. See 425 U.S. at 510 n.5. But see id. at 512 n.9 (conceding that "defense tactic" might have really been "simple indifference"). This interpretation is also consistent with Chief Justice Burger's citation in footnote 3 of On Lee v. United States, 343 U.S. 747 (1952), and United States v. Indiviglio, 352 F.2d 276 (2d Cir. 1965), cert. denied, 383 U.S. 907 (1966), to illustrate that post-conviction courts have refused to remedy errors when counsel has not objected. In both $O_{n}$ Lee and Indiviglio, counsel had objected to the introduction of certain evidence but on a ground different from that urged on appeal. In On Lee, the Supreme Court decided the merits of that ground because the court of appeals had done so, although the Court indicated that the lower court could have denied review. 343 U.S. at 749 n.3. In Intiviglio, the court of appeals refused to address the merits. $352 \mathrm{~F} .2 \mathrm{~d}$ at 277 . But because On Lee and Indiviglio were direct appeal cases where the normal rule is that in the absence of plain error the failure to object bars relief, see id. at 280; FED. R. CRIM. P. 52(b), the Chief Justice's citation to those cases makes little sense unless the Court intends to eliminate the distinction between direct and collateral relief. See United States v. O'Looney, 544 F.2d 385, 392 n.5 (9th Cir.), cert. denied, 429 U.S. 1023 (1976) (on direct appeal Estelle cited in determining waiver).

54. 425 U.S. at 513-14 (Powell, J., concurring). The "consensual relinquishment" test may simply restate the Fay bypass test, but the "inexcusable default" test, taken from Professor Hart, see Hart, Foreword: The Time Chart of the Justices, 73 HARv. L. REv. 84, 118 (1959), resurrects the forfeiture analysis explicitly rejected in Fay. See P. BATOR, P. MISHKIN, D. Shapiro \& H. Wechsler, Hart \& Wechsler's The Federal Courts aNd the Federal SySTEM 258 (2d ed. Supp. 1977) [hereinafter cited as HART \& WECHSLER]. Professor Hart did not define what he meant by his test, but he felt it would help decide cases in state courts, without resort to federal courts. See Hart, supra at 118. Estelle, Francis, and Sykes may fail to achieve such a reduction. See note 212 infra and accompanying text; Part IV infra.

To support his position, Justice Powell also cited the ABA POST-Conviction REMEdies project, supra note $19, \S 2.1$ at $35-37$. But that project concluded that collateral review of an issue should be barred only where the defense had intentionally and inexcusably failed to object. Id. at 36 . Justice Powell's citation of the project therefore implies that he either misinterpreted the post-conviction hearing record, see note 52 supra, or conceived that a decision not to object could be intentional even if counsel does not appreciate the facts or law underlying a possible objection. Without explaining why he could ignore Fay or what interests his limitation would achieve that Fay did not, but see Stone v. Powell, 428 U.S. 465 (1976) (Powell, J.); Schneckloth v. Bustamonte, 412 U.S. 218, 256-75 (1973) (Powell, J., concurring), Justice Powell argued that there was no need to apply the Johnson $v$. Zerbst waiver test to any but fundamental rights. Justice Powell would bar relief whenever counsel, aware of the law and the facts, chose not to object. 425 U.S. at 515 (Powell, J., concurring). On the facts of Estelle, this test means that if the attorney recognizes that he could object and decides for whatever reason not to do so, relief is barred. The defendant need not participate in counsel's decision. Justice Powell did suggest that the habeas court might grant relief if "plain error" resulted from counsel's decision, see id. at $514 \mathrm{n} .2$; since the "plain error" rule is peculiar to direct appeal, this suggestion implies that he, like Chief Justice Burger, is moving toward eliminating the difference between direct and collateral review, see notes 53 supra; 135 infra. 
This interpretation of Estelle, if pushed to its limit, suggests that a counseled defendant may be held to have made a "tactical" decision that bars federal habeas review whenever counsel could have made such a decision, regardless of whether the decision was ever in fact made. ${ }^{55}$ In all its obscurity, Estelle would thereby virtually eliminate the Fay deliberate bypass test without ever mentioning it, ${ }^{56}$ and, without ever addressing the "cause and prejudice" test later developed by Francis and Sykes, would portend the very limitation on federal habeas review achieved by those cases.

\section{B. Francis v. Henderson}

In a 1-day trial, a Louisiana jury convicted 17-year-old Abraham Francis of felony murder for the death of one of his robbery accomplices; he was sentenced to life imprisonment. ${ }^{57}$ Neither of Francis' two defense attorneys had objected to the method of selecting the

55. See Mildwoff v. Cunningham, 432 F. Supp. 814, 821 (S.D.N.Y. 1977) (citing Estelle) (collateral relief barred in part because counsel could have made tactical decision, though no evidence that he had); of. United States v. O'Looney, 544 F.2d 385 (9th Cir.), cert. denied, 429 U.S. 1023 (1976) (Estelle limits strict waiver scrutiny to fundamental rights, not strategic decisions); United States ex rel. Hand v. Redman, 416 F. Supp. 1109, 1110 (D. Del. 1976) (Estelle makes habeas review of state trial judge's failure to give unrequested jury instruction "inappropriate" where state court denied review and there was no denial of due process).

The Court has never indicated whether counsel could bind his client to a decision that bars federal habeas relief when counsel overrides the client in a dispute over that decision. But of. Taylor v. State, 291 Ala. 756, 760, 287 So. 2d 901, 905 (1973) (tactical trial decisions are up to counsel; defendant must choose plea and type of defense).

56. The Fay bypass test might then apply only to the decision to ask for counsel, to appeal, and, probably, to plead guilty. See Henderson v. Morgan, 426 U.S. 637, 644-45 (1976) (counsel cannot bind client to guilty plea without explaining all elements of offense to which plea is made); Brookhart v. Janis, 384 U.S. 1, 5-8 (1966) (counsel cannot agree to a bench trial that is in effect a guilty plea unless client consents); FED. R. CRIM. P. 11. But Chief Justice Burger gave an unexplained "cf." citation to Rule 11 in Estelle after his discussion of counsel's power to bind the client to a "tactical" decision, 425 U.S. at 508 n.3. Was the Chief Justice hinting thereby that Estelle would not even prohibit a finding that collateral relief was barred when counsel pleaded guilty for the defendant without the defendant's consent? See Henderson v. Kibbe, 431 U.S. 145, 158 (1977) (Burger, C.J., concurring) (Fay applicable only to "omissions of a technical nature which would be unlikely to jeopardize substantial state interests") (emphasis added); Henderson v. Morgan, 426 U.S. 637, 656-58 (1976) (Rehnquist, J., dissenting) (if motivated by tactical considerations in arranging guilty plea, counsel need not consult client on all issues relevant to plea). But see ABA PROJECT ON Standards for Griminal Justice, The Prosecution Function and the Defense FunCTION § 5.2(a)(i) (App. Draft 1971).

The Estelle Court's careless treatment of the record and its confusing analysis of the law make it difficult to assess the future force of that decision's implicit restrictions on federal habeas relief. Yet lower courts have not ignored Estelle and have thought that its analysis replaced the Fay deliberate bypass test whenever the right in question was "trial-type." See cases cited in note 55 supra.

57. The facts about Francis and the circumstances of his trial are noted only by the dissent. Francis v. Henderson, 425 U.S. 536, 554 (1976) (Brennan, J., dissenting). Francis' 
grand jury that had indicted Francis, ${ }^{58}$ even though, at the time of the indictment, the local jury commission was systematically excluding daily wage-earners, of whom blacks formed a disproportionate part. ${ }^{59}$ Francis took no direct appeal. ${ }^{60}$ Several years after the verdict, Francis collaterally attacked his conviction in the state courts, claiming, among other things, that the grand jury had been improperly selected. ${ }^{61}$

At the state habeas hearing, Francis testified that his attorneys had not discussed with him the possibility of attacking the grand jury's composition. ${ }^{62}$ Francis' principal trial attorney did not testify at this hearing because of illness. ${ }^{63}$ The associate trial counsel testified that before he took Francis' case, he had himself attacked that jurisdiction's grand jury selection process in other cases and knew of successful attacks by other lawyers in nearby districts. ${ }^{64}$ But the associate counsel admitted that he had not raised, with either the chief counsel or the defendant, the possibility of challenging Francis' in-

two alleged co-conspirators pleaded guilty and received 8-year sentences. Id. Francis is still in prison. Interview with appellate counsel (Mar. 28, 1978).

58. Francis' chief trial attorney, Tureaud, who was appointed but not compensated, had been in failing health and had not practiced criminal law for several years before the trial. 425 U.S. at 554 (Brennan, J., dissenting). He filed only four motions, three on the day before the trial: a request for a bill of particulars, a motion to quash the indictment as vague (Tureaud inserted Francis' name on a form motion supplied by the prosecutor, crossing out the name of another defendant. Interview with appellate counsel (Mar. 28, 1978).) and a motion to discover his client's confession, $i d$. During the trial the court denied Tureaud's motion to suppress the confession. Id.

Tureaud asked another lawyer, Amadee, to help at trial, but Amadee, though characterizing himself as a "trial expert," asked no questions at trial. Petitioner's Appendix in United States Supreme Court at 27, 31. Amadee's role is left unclear by his testimony at the state habeas hearing; he could not explain why Tureaud had not filed other motions or had not filed earlier the motions that he did make, except to note that Tureaud had not handled criminal matters for some years. Id at 31 .

59. 425 U.S. at 555 (Brennan, J., dissenting).

60. Francis' attorneys convinced him to forego direct appeal in exchange for dismissal of a pending robbery charge and because they "didn't want to be tied up for the rest of our lives with a court-appointed [uncompensated] case." Petitioner's Appendix in United States Supreme Court at 36 (testimony of Amadee). Amadee never determined whether the state dropped the robbery charge. Id. at 47.

Francis has apparently never argued that his attorneys' decision to forego appeal amounted to constitutionally ineffective representation. Cf. Bonds v. Wainwright, 564 F.2d 1125 (5th Cir. 1977) (attorney ineffective where he failed to appeal when defendant apparently let him make that decision).

61. Petitioner's Appendix in United States Supreme Court at 76-78.

62. Id. at 61 .

63. Id. at 27.

64. Id. at $26,78$. 
dictment, ${ }^{65}$ nor could he explain why the chief counsel had not raised the claim. ${ }^{66}$ The Louisiana habeas courts denied relief, enforcing that state's procedural rule that barred appellate consideration, on direct or collateral review, of any issue the defendant had failed to raise before trial. ${ }^{67}$

In petitioning for federal habeas relief, Francis was confronted with the possible application of Davis $v$. United States ${ }^{68}$ to a state defendant like himself. Davis had denied access to federal habeas relief to a federal defendant who had failed to meet the federal statutory provision for timely challenge to an indictment ${ }^{69}$ - the same sort of default that Francis had committed. The Court in Davis had asserted that petitioners blocked by the federal procedural bar could gain access to federal habeas relief only if they could establish "cause" to excuse their failure to make a timely claim and "actual prejudice" resulting from that failure. ${ }^{70}$

In Francis, the federal district court did not think Davis controlled, and invoked the Fay deliberate bypass test rather than the Davis test in considering Francis' petition. ${ }^{71}$ Interpreting Fay to require that the defendant alone can waive the opportunity to object,

65. Id. at 31 .

66. Amadee believed that Tureaud might have thought that challenging the grand and petit juries would fail, since blacks were not wholly excluded from either. Id. at 26 . Though never asked why he had not raised the grand jury issue, Amadee did testify that he had not wanted to tell Tureaud, a noted civil rights attorney, what to do. Id. at 26,31 .

67. Id. at 76-79. At the time of Francis' trial, Louisiana law held that an objection to the grand jury was waived if not made before the end of the third day after the grand jury's term had expired or before trial, whichever occurred earlier. LA. CODE CRIM. PRO. ANN. art. 202 (West 1951) (current version at id. art. 535 (B)(5) (West 1967)).

The state habeas court also found that Francis' two attorneys had not been ineffective and also credited the associate counsel with having recognized that he could have challenged the grand jury panel and yet having deliberately chosen not to do so. Petitioner's Appendix in United States Supreme Court at 77, 78.

68. 411 U.S. 233 (1973).

69. FED. R. CRIM. P. 12(b)(2), (f).

70. 411 U.S. at 242,245 . The federal statute provides that post-conviction attack is "waived" unless the defendant establishes "cause" to excuse the failure to object. FED. R. CRIM. P. 12(f). The Davis Court added "actual prejudice" as an independent test. 411 U.S. at 245. In Shotwell Mfg. v. United States, 371 U.S. 341, 363 (1963), the Court had approved of the district court's consideration of whether the defendant in that case had been "prejudiced" as a factor in assessing "cause." Whether Shotwells "prejudice" was different from Davis" "actual prejudice" was not explained in Davis, a question that Estelle, Francis, and Sykes also fail to answer. On its face, Rule 12 does not indicate whether it should be applied to collateral, as well as to direct attacks. Although Shotwell was a direct appeal, the Davis Court thought that Rule 12 should also apply to collateral attacks by federal prisoners under 28 U.S.C. $\S 2255$ (1970). 411 U.S. at $240-43$ (1973).

71. The district court thought that Davis had not eliminated federal habeas for a state prisoner like Francis who had gone to trial, Francis v. Henderson, No. 72-719"G" (E.D. La. Sept. 20, 1973), reprinted in Petitioner's Appendix in United States Supreme Court at 87, 91, 
the district court held that Francis had not committed a deliberate bypass; ${ }^{72}$ it further found that even if Davis controlled, Francis had established "cause" by showing that his principal trial attorney was a "civil lawyer, unskilled in the intricacies of criminal practice, who had, by his inexperience," let the time to object pass. ${ }^{73}$ The district court thus reached the merits of the constitutional issue, found that the grand jury had been unconstitutionally selected, and reversed Francis' conviction. ${ }^{74}$

The Fifth Circuit Court of Appeals decided that Davis established the test for state prisoners and remanded to the district court to determine whether Francis could prove he had been prejudiced by the failure to object. ${ }^{75}$ The court of appeals neither disturbed nor discussed the district court's finding of "cause."

In a cursory opinion, the Supreme Court affirmed the remand, ${ }^{76}$ and placed the state's procedural rule in the way of federal habeas review. The Court explained that the issue was not whether the habeas court had the power to exercise jurisdiction but whether, in its equitable discretion, it should exercise that power. Comity and federalism, the Francis Court concluded, required that the same principles that governed the availability of habeas relief to the federal defendant in Davis must apply to a state defendant like Francis. ${ }^{77}$ Applying these principles, the Court followed its earlier holding in Davis that the government's interest in finality outweighs the defendant's interest in review of the issue. ${ }^{78}$ In order to justify a grant of federal

and that Francis' questionable waiver of his right to directly appeal his conviction did not bar federal habeas review, Petitioner's Appendix in United States Supreme Court at 90.

72. Petitioner's Appendix in United States Supreme Court at 89, 90.

73. See Newman v. Henderson, 496 F.2d 896, 897-98 (5th Cir. 1974). The district court did not find that either Tureaud's or Amadee's representation was constitutionally ineffective under the sixth amendment, although their perfunctory representation smacked of ineffectiveness. Petitioner's Appendix in United States Supreme Court at 78.

74. See Newman v. Henderson, 496 F.2d 896, 897-99 (5th Cir. 1974).

75. Id. at 897-98. The district court had not discussed the issue of prejudice.

76. Francis v. Henderson, 425 U.S. 536 (1976).

77. The Court did not discuss whether Congress intended through enactment of Rule 12 , the federal procedural bar, to treat federal defendants differently from state defendants. For a blistering criticism of this omission in Francis, see HART \& WECHSLER, supra note 54, at 256-57.

78. Davis v. United States, 411 U.S. 233, 242 (1973); see Francis v. Henderson, 425 U.S. 536, 542 (1976) (quoting Kaufman v. United States, 394 U.S. 217, 228 (1969)). The Davis Court thought that any defendant had a strong tactical motive to delay his objection to the grand jury until habeas review. It reasoned that the defendant would not profit from a successful objection made in compliance with the procedural rule: The government would simply reindict him with a properly selected grand jury. But raising the claim much later on habeas review might free a convicted defendant, since the prosecution might find it practi- 
habeas relief, the state defendant, like the federal defendant in Davis, must establish "cause" for the failure to comply with the state's procedural rule and "actual prejudice" suffered as a result of the failure. ${ }^{79}$

The decision in Francis left several questions unanswered. The Court neither reconciled its decision with the earlier decisions in Fay and Henry nor even mentioned the deliberate bypass test. The Court thus did not discuss whether a defense decision not to object until habeas review would constitute a deliberate bypass within the meaning of Fay or whether the federal habeas court would have difficulty in ascertaining whether the defense had made that type of decision. Nor did the Court discuss whether counsel's incompetency might instead explain why he or she had not objected. Moreover, in applying the new "cause and prejudice" test, the Court did not explain whether these requirements applied to constitutional issues other than an attack on the institution of the criminal proceedings. ${ }^{80}$ Nor did the Court discuss whether the district court's finding of "cause" was correct. Finally, although it suggested that proving "actual prejudice" required more than just a showing of a constitutional violation, ${ }^{81}$ Francis failed to give any definitive content to the "actual prejudice" test. Wainwright $v$. Sykes, though it also fails to provide clear guidance on the meaning of "cause and prejudice," more firmly establishes that test as the new law on federal habeas, and therefore

cally impossible to reconstruct its case. Davis v. United States, 411 U.S. 233, 241 (1973). And, as the Francis Court noted, the government, years after the original indictment, might not easily find the evidence necessary to rebut a prima facie showing by the defendant that the grand jury had been improperly selected. Francis v. Henderson, 425 U.S. 536, 541-42 (1976) (citing Michel v. Louisiana, 350 U.S. 91, 98 n.5 (1955)); see note 252 infra.

79. 425 U.S. at 542. The Court did not explain how Francis might establish actual prejudice, a task that would probably prove impossible. See Peters v. Kiff, 407 U.S. 493, 504 (1972) (proof of harm impossible to adduce when jurors are excluded on basis of race). On remand to the federal district court, the state moved for summary judgment, arguing that Francis could never prove actual prejudice, and also moved to quash the defense attempt to discover any information about the grand jury's proceedings in Francis' case. Interview with appellate counsel (Mar. 26, 1978); see note 153 infra.

80. The Davis Court had expressly limited its holding to "claims of defects in the institution of criminal proceedings," as Rule 12(b)(2) provided at the time of that decision. Davis v. United States, 411 U.S. 233, 241 (1973).

81. The Court did not challenge the district court's holding that the grand jury selection was in fact unconstitutional. See 425 U.S. $538 \mathrm{n} .2$. Francis is distinguished from Davis by this factor, as well as by the fact that Davis' counsel, far from being arguably ineffective like Francis', had been complimented on his performance by the court of appeals, Davis v. United States, 409 F.2d 1095, 1101 (5th Cir. 1969), and by the relative weakness of Davis' claim of grand jury prejudice: The grand jury that had indicted him had also indicted two white accomplices. See Davis v. United States, 411 U.S. 233, 235 (1973). 
provides the best opportunity for a close analysis of the Court's new work.

\section{Wainwright v. Sykes}

A jury convicted John Sykes of third-degree murder. At the trial, defense counsel did not object when the prosecution introduced the defendant's statements to the police in which he confessed to the killing. ${ }^{82}$ On direct and collateral review, the Florida state courts denied Sykes' attack on his conviction without opinion, apparently by enforcing a state contemporaneous objection rule which held that failure to object constituted a waiver of that objection. ${ }^{83}$

In his habeas petition to the federal district court, Sykes claimed that he had been drunk when he encountered the police and therefore had not intelligently waived his Miranda rights. ${ }^{84}$ The district court interpreted the Supreme Court decision in Jackson v. Denno as requiring the state trial court to determine-on its motion, if the defendant fails to object-whether the defendant's statements were constitutionally admissible. ${ }^{86}$ In remanding to the state courts to make that determination, the district court took no evidence on why the defense attorney had not objected or on whether the defendant had agreed that counsel should not have objected. ${ }^{87}$

82. See Wainwright v. Sykes, 433 U.S. 72, 75 (1977).

83. Interview with appellate counsel (Mar. 15, 1978).

84. See Wainwright v. Sykes, 528 F.2d 522, 523 (5th Cir. 1976). The district court opinion, No. 73-316-Civ.-T-H (M.D. Fla. Jan. 22, 1975) is unreported. The record in the Supreme Court did not clearly indicate what statements the government had introduced at trial or what warnings the police had given Sykes. At both the scene of the crime and the police station, Sykes had apparently admitted shooting the victim. The Court characterized the on-the-scene statement as voluntary, 433 U.S. at 74, but the trial transcript left in doubt whether Sykes had been given the Miranda warnings at the scene before the first statements were made. $528 \mathrm{~F} .2 \mathrm{~d}$ at 524 n.4. The federal district court noted that a government witness testified that somebody had given Sykes his "constitutional rights" at the scene, but did not remember who had done that, what those "rights" were, or whether Sykes had appeared to understand them. Petitioner's Appendix in United States Supreme Court at A-28, A-29. The district court also noted that two sheriff's deputies had testified that they had read Sykes his "rights" at the jail, but did not testify to what "rights" they had read, or to whether Sykes had understood them. Id. at A-29.

85. 378 U.S. 368 (1964) (trial court must itself decide admissibility of confession before jury can hear it).

86. See 528 F.2d at 524 .

87. Petitioner's Appendix in United States Supreme Court at A-31. The district court thought that the state had not carried its burden of justifying the admission of the statements, and remanded to give the state courts the opportunity to develop additional information. If the state court failed to act within 90 days, the district court was prepared to proceed and apparently to rule for the defendant. The state appealed that remand order. Id. at A-29. 
The Fifth Circuit Court of Appeals affirmed the remand.88 Though nothing on the record showed why counsel had not objected, or whether the defendant knew of and agreed with counsel's reasons for not objecting, or what prejudice the failure to object might have caused, the court of appeals held that a remand was necessary under either the Fay bypass test or the Davis cause and prejudice test: ${ }^{89}$ It found both an absence of deliberate bypass and the existence of "cause," because it refused to infer a waiver-even by counsel-from a silent record, and it could divine no tactical advantage that counsel might have hoped to achieve by deciding not to object. ${ }^{90}$ In contrast to its decision in Francis, ${ }^{91}$ where it had expected the defendant to prove the prejudice caused by the unconstitutionally selected grand jury, the Fifth Circuit in Sykes found "actual prejudice" by concluding that the government's use of the defendant's statement was inherently harmful. ${ }^{92}$

The Supreme Court reversed the remand and ordered that the petition be dismissed. ${ }^{93}$ Without renouncing the Court's power to exercise habeas review, ${ }^{94}$ the Court acknowledged, as it had not done in Francis, that it intended to replace the Fay deliberate bypass test with the cause and actual prejudice test whenever the defendant failed to comply with the state's procedural rule governing the timing of objections. ${ }^{95}$ This acknowledgement made reversal inevitable, since the defendant had not attempted to meet the burden of either part of the new test: He had not shown why the attorney had not

88. Wainwright v. Sykes, 528 F.2d 522 (5th Gir. 1976).

89. The court of appeals noted the conflict between Fay/Henry and Davis but did not resolve which doctrine controlled. See id. at 525-27.

90. Id. at 525-27. The appeals court thought that the state had the burden of showing deliberate bypass.

91. See note 75 supra and accompanying text.

92. 528 F.2d at 525-27. The court of appeals did not discuss how the government's use of the statement had specifically harmed the defendant or whether the error, if any, was harmless.

93. Wainwright v. Sykes, 433 U.S. 72, 91 (1977).

94. Writing for the Court, Justice Rehnquist reviewed earlier Supreme Court decisions to illustrate how the Court has changed the scope of habeas review even though congressional authorization of habeas jurisdiction did not change. Id. at 81 .

95. Id. at 87-88. Justice Rehnquist did not discuss whether deliberate bypass could have been made workable by clearly assigning the burden of proof and by providing the petitioner with a way to develop relevant information on that issue, both problems that plagued habeas review after Fay/Henry. Nor did he consider whether the problems of developing the record could have been reduced, if not eliminated, if the trial court were required to ask counsel why he did not make some obviously pertinent motion or request. Counsel's answer would provide a record to evaluate deliberate bypass and to test counsel's effectiveness. As Estelle indicates, however, the Court has no intention of forcing the trial court to intercede in the defense case. 425 U.S. 501, 512 (1976); see notes 274-75 infra and accompanying text. 
objected, and he was not entitled to a presumption of harm. Perhaps because it thought the government's case against Sykes so strong as to rebut any possible claim of prejudice, ${ }^{96}$ the Court did not, as it had done in Francis, ${ }^{97}$ remand to the lower court to permit the defendant to develop the evidence he needed to meet the cause and prejudice test. ${ }^{98}$ Yet despite the firmness with which the Sykes Court pronounced the advent of the cause and prejudice test, it left the meaning of that test vexingly enigmatic. ${ }^{99}$ The next part of the article attempts to unravel that enigma.

\section{Defining the "Cause and Prejudice" Rule: The Remaining Avenues for a Habeas Petitioner}

The present Court has virtually rejected the Fay Court's willingness to provide habeas review. ${ }^{100}$ The defendant will be barred if he

96. 433 U.S. at 91 . This surmise is surprising, since the state appeared to concede during oral argument before the Court that Sykes had been prejudiced. Transcript of Oral Argument at 10-11 (Mar. 29, 1977).

97. See note 75 supra and accompanying text.

98. The Court's refusal to remand was unfair, because, without testimony or an affidavit from trial counsel, the defendant could not determine why counsel had not objected, or what prejudice he might have suffered. Moreover, because Fay and Henry left unanswered the question of which side carried the burden of production or persuasion, see notes 180-87 infra and accompanying text, the defendant might decide not to approach trial counsel to get an affidavit to submit with his habeas petition. But Sykes' federal appellate counsel did not make that decision. Ironically, he apparently chose not to ask trial counsel why the latter had not objected so that he could avoid the deliberate bypass question if asked by the federal habeas courts. Interview with appellate counsel (Mar. 15, 1978). Trial counsel does not now remember why he did not object. He now recognizes that he could have objected, but believes that he saw no reason to object because he had not thought the government's use of Sykes' statements was inconsistent with the defense case. Interview with trial counsel (Mar. 29, 1977).

99. The Court only explained that "[w]e leave open for resolution in future decisions the precise definition of the 'cause'-and-'prejudice' standard, and note here only that it is narrower than the standard set forth in dicta in Fay $v$. Noia . . . . It is the sweeping language of Fay . . . which we today reject." 433 U.S. at 87.

100. Whatever uncertainty the Court has caused for the future of habeas corpus, two points are clear. First, habeas relief is equitable and discretionary in nature. Wainwright v. Sykes, 433 U.S. 72, 95-96 \& n.4 (1977) (Stevens, J., concurring); see Stone v. Powell, 428 U.S. 465,478 n.11 (1976); Francis v. Henderson, 425 U.S. 536, 538-39 (1976). The habeas court is free to decide on the totality of the circumstances whether to grant relief. See United States v. Williams, 544 F.2d 1215 (4th Cir. 1976) (habeas court has discretion to decide whether to grant relief for noncompliance with FED. R. CRIM. P. 12). Second, habeas relief is reserved only for the most deserving defendants. Since the purpose of habeas review is no longer to provide a federal forum to review constitutional issues not adjudicated below, or to ensure the equal enforcement of federal constitutional rights, the focus will be on whether the individual petitioner deserves relief for the most exigent reasons. See Wainwright v. Sykes, 433 U.S. at 91 (cause and prejudice do not bar relief to prevent a "miscarriage of justice"); United States v. Williams, 544 F.2d at 1218 (relief under Rule 12 viewed as exercise of "extraordinary 
or she waives or forfeits the right to challenge the government's conduct. ${ }^{101}$ The defendant waives even under Fay by personally making

power that must be regarded as an exception to the rule"); $c$. White, Federal Habeas Corpus: The Impact of the Failure to Assert a Constitutional Right at Trial, 58 VA. L. REv. 67, 81-82 (1972) (where counsel has deliberately bypassed opportunity to object, habeas relief should be available only if collateral attack would "benefit society").

The Court has not squarely considered whether it is authorized by the Constitution or by Congress to alter the law of federal habeas corpus. While acknowledging that federal habeas jurisdiction is a creature of congressional authorization, see Swain v. Pressley, 430 U.S. 372 (1977), the Court has cut back its exercise of habeas jurisdiction even though Congress has not clearly intended that that be done. In Davis, for example, the Court cited no legislative history in concluding that Congress must have intended that Rule 12's "cause shown" requirement bar habeas review as well as direct review of an issue counsel did not raise at trial. And if Davis lacked a clear congressional imprimatur, Francis had none whatsoever, a lack that perhaps explains why the Court used an analysis bottomed on comity rather than on congressional intent. The Court has also ignored the question whether Congress' refusal to restrict federal habeas is an implicit confirmation of broader habeas review than Francis/Sykes provide. See note 24 supra. Conversely, one wonders whether the Court would exercise its equitable discretion to refuse to follow new legislation that overturned the Francis/Sykes/Stone $u$. Powell restrictions on habeas review. See S. 1314, 95th Cong., 1st Sess. (1977) (proposed legislation to overturn Francis and Stone). Three Justices even think that congressional elimination of federal habeas review would be constitutional. See Swain v. Pressley, 430 U.S. at 385-86 (Burger, C.J., concurring with whom Blackmun and Rehnquist, J.J., join).

The waiver test will remain the Fay analysis of whether the defendant himself made an informed, voluntary decision. The forfeiture test will involve a comparison of the defendant's interests in gaining review with the state's interests in barring review. In the future, federal habeas courts will probably use this comparative analysis to decide whether to apply the Fay test or the Estelle/Froncis/Sykes test to the issue raised by petitioner. See Castaneda v. Partida, 430 U.S. 482, 508 n.1 (1977) (Powell, J., dissenting) (comparison of cost to benefit might eliminate grand jury discrimination questions from federal habeas altogether).

The counseled defendant, however, can waive but probably cannot forfeit an issue that would eliminate the state court's jurisdiction even if he fails to object and even if he pleads guilty. See Menna v. New York, 423 U.S. 61, 62 n.2 (1975) (per curiam) (pleading guilty to unlawfully possessing unregistered firearm does not constitute waiver of prior constitutional claim of privilege against self-incrimination); Blackledge v. Perry, 417 U.S. 21 (1974) (where defendant obtains trial de novo on misdemeanor by exercising an automatic right of appeal, government may not proceed instead to prosecute defendant for a felony based on same conduct) (habeas not waived by guilty plea to felony); $f$. Davis v. United States, 417 U.S. 333 (1974) (collateral attack available where circuit court voids statute under which defendant convicted while direct appeal pending); Haynes v. United States, 390 U.S. 85 (1968) (claim that statute defining crime is unconstitutional not waived by counseled guilty pleas). But see Commonwealth v. McKenna, 46 U.S.L.W. 2424 (Pa. Feb.21, 1978) (because of society's concern with capital punishment, defendant who prefers death to imprisonment cannot waive constitutional attack on death penalty).

101. See note 33 supra and accompanying text. The absence of a procedural rule should make a difference, justifying federal habeas relief even without proof of cause and prejudice, since such a rule would alert counsel to the importance of objecting. Cf. Murch v. Mottram, 409 U.S. 41, 46 (1972) (defendant may not evade state procedural rules by claiming he did not intend to waive constitutional claim).

The question of Estelle's direct application to federal habeas review must be answered for any federal court that seeks to limit the application of Francis and Sykes by interpreting those cases as not barring habeas relief where counsel's failure to object violated no state procedural rule or by distinguishing the particular state procedural rules in those cases from another rule 
an intelligent and voluntary decision not to object. If counsel fails to object and the defendant cannot prove "cause" and "actual prejudice" to excuse counsel's failure, the defendant forfeits whenever the state has a rule governing the timing of objections, and perhaps, as suggested by Estelle, even when the state does not. ${ }^{102}$

In establishing this test, however, the Court deliberately avoided giving "precise content"103 to "cause" and "actual prejudice." This

before it. See Bromwell v. Williams, 445 F. Supp. 106, 112-14 (D. Md. 1977) (state procedural bar enforced in state courts to bar review of defense claim differs from that in Sykes and Francis because it is not "specifically and solely keyed to trial developments"; court does not explain significance of difference but reaches merits of claim). Bromwell's distinction is meaningless if Estelle limits habeas review. But see cases cited in note 55 supra. But the question of Estelle's application to habeas cannot yet be answered: The Court's opinion in Estelle is too ambiguous, not even mentioning habeas corpus, Francis did not refer to Estelle, and Sykes cited the majority opinion in Estelle only for the point that the attorney controls every tactical decision. Wainwright v. Sykes, 433 U.S. 72, 91 n. 14 (1977). Several factors suggest, however, that Estelle does apply to habeas. Chief Justice Burger, for example, has cited Estelle in arguing that federal habeas should have been barred when the defendant had not complied with a state procedural rule. Henderson v. Kibbe, 431 U.S. 145, 158 (1977) (Burger, C.J., concurring). Sykes described Justice Powell's Estelle test of "inexcusable procedural default," see note 54 supra and accompanying text, as designed to achieve the same values that prompted creation of the cause and prejudice tests. 433 U.S. at 89 n.13. Several of the reasons given by the Sykes Court to restrict federal habeas review, see notes 197-211 infra and accompanying text, apply equally where no procedural rule exists: determining all issues at trial when witnesses' memories are fresh and the trial judge can remedy error, developing a record for the habeas court, and ending litigation.

102. Denying habeas review of claims unraised at trial even in states that have no procedural bar rule may find additional support in Stone v. Powell, 428 U.S. 465 (1976), which barred habeas review of fourth amendment issues whenever the state had provided the defendant with "an opportunity for full and fair litigation" of that issue-even if the state court did not decide the merits. Id. at 494. Commentators have focused on what a "full and fair hearing" might be. See Tushnet, Judicial Revision of the Habeas Corpus Statules: $A$ Note on Schneckloth v. Bustamonte, 1975 WIS. L. REv. 484, 495-96 (responding to the appearance of the phrase in an earlier case); Note, Stone v. Powell: The End of Collateral Review for Fourth Amendmenl Claims by State Prisoners?, 13 CAL. W. L. REv. 558, 583-86 (1977). But the key word may be "opportunity." That term of art suggests that federal habeas review may disappear when the defense does not object-even in the absence of a state contemporaneous objection rule-so long as the state provides trial and appellate review of claims which are timely raised. In Sykes, because the state had not argued the point, the Court did not decide whether Stone would bar federal habeas review of petitioner's fifth amendment claim. 433 U.S. at $87 \mathrm{n} .11$. Since the state courts had not addressed the merits of the fifth amendment claim, Sykes may have been reserving the possibility of such a reading of Stone. This extension of Slone is supported by the federal abstention doctrine: A federal court may not intervene to block a state proceeding if the individual had "an opportunity to present [his or her] federal claims in the state proceedings," even if the state courts neither held "an actual hearing" nor decided the claim. Juidice v. Vail, 430 U.S. 327, 337 (1977) (emphasis in original).

103. See Wainwright v. Sykes, 433 U.S. 72, 91 (1977). However much the Sykes tests will restrict federal habeas jurisdiction, they will not return that jurisdiction to its bounds under Daniels v. Allen, 344 U.S. 443 (1953) (reported with Brown v. Allen). In Daniels the state courts denied appellate review because the defendant filed his notice of appeal one day late. 
failure is cavalier, if not incomprehensible, if one of the Court's purposes in limiting federal habeas is to make it easier for the lower federal courts to deny review instead of reaching the merits of the issue counsel failed to raise. Without clear direction from the Court, federal habeas courts will find it no easier to decide what "cause" and "actual prejudice" mean than to settle the jumble of issues Fay and Henry left unanswered concerning the meaning of deliberate bypass. Understandably, some federal district courts have responded to Estelle, Francis, and Sykes by deciding the merits of the issue even after deciding that they lack jurisdiction to do so, apparently to prevent a remand if a higher court disagrees with their application of the new Supreme Court test. ${ }^{104}$

This part attempts to give more precise content to "cause and prejudice." It suggests the criteria by which future courts will apply the cause and prejudice test, and examines the defendant's likely burden of proof on these questions, a burden the Court never clearly delineated.

\section{A. Cause}

In attempting to discern the content of the "cause" test, the most reliable guide ${ }^{105}$ may well be the facts of Estelle and Sykes. ${ }^{106}$ In

The Supreme Court refused habeas review, respecting the state's procedural bar, because the petitioner had not shown that his late filing was caused by "lack of counsel, incapacity, or some interference by officials." Id. at 485-86.

104. See, e.g., Richardson v. Stone, 421 F. Supp. 577 (N.D. Cal. 1976). Lower courts frequently approached the issue of deliberate bypass in the same way: Rather than decide that issue, they denied the petition on the merits. See ABA Post-Conviction Remedies, supra note $19, \S 2.1$, at 36 .

105. There are three other potential sources: (1) the judicial interpretation of the "cause shown" requirement of FED. R. CRIM. P. 12(f); (2) the judicial treatment of deliberate bypass; and (3) the judicial doctrine of constitutionally ineffective representation. Neither of the latter two sources are helpful because of the great disagreement about the type of attorney conduct encompassed by the two doctrines. On deliberate bypass, see notes $11-12$ supra and accompanying text. But see Wainwright v. Sykes, 433 U.S. 72, 98 (1977) (White, J., concurring) (defining cause in terms of absence of deliberate bypass). For the ineffective representation doctrine, see notes 297-307 infra and accompanying text. Judicial interpretation of Rule 12(f) provides some useful examples, but these cases do not necessarily give content to the new "cause" test, because the federal courts consider a determination of "cause shown" to be part of their inherent power, independent of the rule, to "do justice" in a particular case. See United States v. Jones, 322 F. Supp. 1110, 1112 (E.D. Pa. 1971) (treating former Rule 12(b)). See also United States v. Rosenson, 291 F. Supp. 867, 872 (E.D. La. 1968) (reasonableness in Rule 12 is factual question "sprinkled with a measure of discretion"), affd per curiam, 417 F.2d 629 (5th Cir. 1969), cert. denied, 397 U.S. 962 (1970). Professor Moore's suggestion that determination of "cause shown" is really a determination of "plain error" indicates that Rule 12 cases may also not be congruent with Francis/Sykes "cause" because "plain error" may not be enough to satisfy even "actual prejudice" under Francis and Sykes. See 8 MOORE's FEDERAL PRACTICE ๆ 12.03 [3], at 12-22 (2d ed. 1977) [hereinafter cited as MOORE]; note 135 infra and accompanying text. 
Estelle, the attorney recognized the issue involving the jail clothes, but did not know either the law or the facts relevant to that issue. He decided not to object simply because he thought, erroneously, that the motion would be denied and not because he hoped either to achieve some tactical advantage or to avoid some potential damage to his client's case. ${ }^{107}$ In Sykes, although nothing in the record explains why the attorney did not object, ${ }^{108}$ even a successful motion might not have helped his client, because the government could have used the statement to impeach the defendant when he testified. ${ }^{109}$

If Estelle and Sykes illustrate the defendant's burden, few defendants will be able to establish cause. If the attorney exercises professional judgment, ${ }^{110}$ perhaps simply if the attorney consciously

Courts thus treat Rule 12(f) "cause shown" as involving a fluid and fluctuating relationship between counsel's reasons for not making a timely objection, the merits of the objection, the prejudice that the defendant would suffer if the claim underlying the objection were not decided, and the question whether counsel at least made an objection after the time provided by the rule. See Wells v. Wainwright, 488 F.2d 522, 523 (5th Cir. 1973); Partida v. Castaneda, 384 F. Supp. 79, 84 (S.D. Tex. 1974), rev'd, 524 F.2d 481 (5th Cir. 1976), affd, 430 U.S. 482 (1977). The Supreme Court's approach to "cause" in Francis and Sykes appears instead to focus solely on counsel's conduct, considering the other fartors as part of the "prejudice" test. See notes 130-79 infra and accompanying text.

106. Unfortunately, the Francis Court did not discuss the district court's finding of cause. That discussion might have illuminated the relationship between Francis' "cause," FED. R. CRIM. P. 12's "cause," and ineffective representation. The district court's finding of Rule 12 cause was probably wrong because the trial attorney apparently knew of the motion to quash the indictment and surely could have discovered the factual basis for the motion since other attorneys had apparently challenged the same grand jury selection process that led to the indictment of Francis. See note 64 supra and accompanying text. Moreover, in apparently finding counsel ineffective the district court focused on counsel's overall performance rather than upon his failure to object to the grand jury, a focus that may also be wrong. See notes 192 \& 299 infra.

107. See note 37 supra and accompanying text.

108. See text accompanying note 89 supra.

109. See Wainwright v. Sykes, 433 U.S. 72, 96-97 (1977) (Stevens, J., concurring). Justice Stevens' concurring opinion in Sykes is the most perplexing road sign to the Court's eventual definition of cause and prejudice. He argued that those tests were consistent with the way federal courts had interpreted deliberate bypass. Id. at 94-95 \& n.1. But his illustrations weaken his argument, because the cases differ in determining whether counsel had made a decision and what sort of decision counsel had had to make. See, e.g., Minor v. Black, 527 F.2d 1 (6th Cir. 1975) (court does not speculate about counsel's failure to object); Whitney v. United States, 513 F.2d 326 (8th Cir. 1974) (court speculates about counsel's failure to object and concludes that he made deliberate decision); United States ex rel. Cruz v. LaVallee, 448 F.2d 671 (2d Cir. 1971), cert. denied, 406 U.S. 958 (1972) (court speculates that counsel's use of confession is consistent with trial strategy).

110. See Wainwright v. Sykes, 433 U.S. 72, 98-99 (1977) (White, J., concurring). This definition of cause is consistent with the refusal to review the reasonableness of tactical judgments by counsel as a basis for ineffective representation. See Whitney v. United States, 513 F.2d 326 (8th Cir. 1974). 
decides not to object, ${ }^{111}$ the defendant will be barred from habeas relief. It is not enough for the defendant to show that counsel failed to research or to understand the law, ${ }^{112}$ or objected on the wrong ground, ${ }^{113}$ or failed to get a ruling on the objection from the trial court, ${ }^{114}$ or failed to discover the information upon which the objection was based in time to comply with the procedural rule. ${ }^{115}$ It is not enough for the defendant to show that counsel wrongly decided that the motion would be denied, ${ }^{116}$ or that counsel was not motivated by either the hope of gaining some tactical advantage or of avoiding some possible harm, ${ }^{117}$ or that the defendant disagreed with counsel's decision. ${ }^{118}$ And there is no suggestion in Estelle, Francis, or Sykes that the habeas court must review the reasonableness of the attorney's decision. ${ }^{119}$ Finally, it is not enough to show that counsel did not know of the information that would have supported an objection, at least if this information was reasonably discoverable. ${ }^{120}$

111. If FED. R. CRIM. P. 12 provides the definition of cause, it may not even be enough to show that counsel did not decide against objecting, if he could have discovered the information to warrant that objection. See Shotwell Mfg. Co. v. United States, 371 U.S. 341, 362-63 (1963); Scales v. United States, 260 F.2d 21, 46 (4th Cir. 1958), affd, 367 U.S. 203, 259 (1961).

112. See Estelle v. Williams, 425 U.S. 501 (1976); øf. United States v. Agurs, 427 U.S. 97, 102 n.5 (1976) (counsel's ignorance of law not ineffective representation).

113. This limitation assumes that Estelle eliminated the difference between direct and collateral attack. See note 53 supra; cf. United States v. Radetsky, 535 F.2d 556, 571 (10th Cir. 1976) (defense barred from introducing evidence of discriminatory prosecution during trial because that objection should have been presented as motion to dismiss indictment rather than as affirmative defense; no explanation why counsel proceeded as he did). But of. Allen v. County Court, 568 F.2d 998 (2d Cir. 1977) (habeas not barred where petitioner objected at trial and on appeal on substantially same ground as urged on collateral attack).

114. Cf. Gates v. Henderson, 568 F.2d 830, 839-40 \& n.8 (2d Cir. 1977) (en banc) (objection at trial on ground other than one raised in habeas petition).

115. See Scales v. United States, 260 F.2d 21, 46 (4th Cir. 1958) (defense objected but not within Rule 12's time provisions; objection waived because "information on which motion was based was at all times available"), affd, 367 U.S. 203 (1961).

116. See United States v. Smith, 551 F.2d 348, 354 (D.C. Cir. 1976) (habeas barred where counsel's decision not to object appears sound and reasonable in retrospect, even if incorrect).

117. Cf. id. at 353-54 n.7 (unclear why counsel failed to object except perhaps to avoid irritating judge).

118. See Nelson v. California, 346 F.2d 73 (9th Cir. 1965) (counsel's deliberate bypass bars defendant who wanted counsel to object); of. United States ex rel. Brown v. Warden, 417 F. Supp. 970 (N.D. Ill. 1976) (counsel's deliberate bypass of appeal issue binds defendant even if done without defendant's knowledge and consent).

119. If the petitioner frames his habeas petition as an attack on counsel's competency for having failed to object, the habeas court probably must review the reasonableness of the counsel's decision. See Nelson v. California, 346 F.2d 73, 82 (9th Cir. 1965) (reviewing merits of objection counsel deliberately bypassed). See also Part IV infra.

120. Counsel is apparently held to constructive notice of that information. See Davis v. United States, 411 U.S. 233, 235 (1973) (collateral review barred where method of selecting 
There are, however, several ways the defendant might establish cause. First, if counsel did object, albeit out-of-time, the defendant could show that counsel's failure to strictly comply with the procedural rule was inadvertent and not deliberate. ${ }^{121}$ Second, the defendant could show that the attorney did not actually decide to refrain from objecting: ${ }^{122}$ Counsel might have lacked the competence to recognize the issue; ${ }^{123}$ the practice challenged on post-conviction appeal may have been so customary in the jurisdiction that a reasonable trial attorney might not have objected; ${ }^{124}$ the government may have failed to reveal information that would have alerted counsel to

grand jurors had been "openly followed for many years prior to petitioner's indictment"); Shotwell Mfg. Co. v. United States, 371 U.S. 341, 363 (1963) (no cause under FED. R. CRIM. P. 12 where grand jury selection process used for years); of. Estelle v. Williams, 425 U.S. 501 (1976) (counsel could have determined that trial judge would have granted objection to jail clothes). See also Wells v. Wainwright, 488 F.2d 522 (5th Cir. 1973) (remanding to determine whether counsel could reasonably have discovered information but not clearly indicating whether such finding would bar collateral attack).

121. See United States v. Hall, 565 F.2d 917 (5th Cir. 1978) (interpreting FED. R. CRIM. P. 12(f)); United States v. Jones, 322 F. Supp. 1110, 1112 (E.D. Pa. 1971) (late objection caused by "bureaucratic bungling"; government had time to prepare a response).

If the trial court did not appoint counsel until after the time for filing objections had passed, or if the court could cure any error even if counsel's objection was late or did not comply with the technical requirements of the state's procedural requirements, the federal habeas court should have no reasonable interest in enforcing the state's procedural bar. See Huffman v. Florida, 98 S. Ct. 1888 (1978) (Marshall, J., dissenting from denial of certiorari); Chambers v. Maroney, 399 U.S. 42, 56 (1970) (Harlan, J., dissenting in part); Henry v. Mississippi, 379 U.S. 443 (1965). Additionally, cause might exist if the state court itself interfered with counsel's decision. Cf. White v. Estelle, 566 F.2d 500 (5th Cir. 1978) (court forced counsel to proceed to trial on case for which he had not been retained).

122. See Wainwright v. Sykes, 433 U.S. 72, 99 (1977) (White, J., concurring). See also Reitz, Federal Habeas Corpus: Impact of an Abortive State Proceeding, 74 HARV. L. REV. 1315, 1367 (1961).

123. The relationship between ineffective representation and cause is unsettled and presents a difficult question for the Supreme Court to resolve to protect its purpose in restricting habeas review. See Part IV infra. Counsel has been held ineffective for having failed to comply with procedural rules that might bar habeas review under Estelle, Francis, and Sykes. See Johns v. Perini, 462 F.2d 1308 (6th Cir. 1972) (failure to investigate alibi defense led to failure to comply with alibi notice statute); People v. Ibarra, 60 Cal. 2d 460, 386 P.2d 487, 34 Cal. Rptr. 863 (1963) (counsel ineffective where failure to object to admission of evidence resulted from ignorance of law). But while proof of ineffective representation should establish cause, it should not be required for a showing of cause. Cause should also be inferred from reasons for a failure to object other than counsel's sloth or ignorance. See notes 124-29 infia and accompanying text.

124. See Bromwell v. Williams, 445 F. Supp. 106 (D. Md. 1977) (cause established where neither defense, prosecutor, nor judge recognized that jurisdiction's usual practice of arguing consolidation motions before jury panel presented due process problems). But of. Arnold v. Wainwright, 516 F.2d 964, 971-72 (5th Cir. 1975) (no cause even if crucial facts are discovered inadvertently, and other local defense lawyers had also failed to ferret out relevant facts to attack grand jury selection process). 
the issue; ${ }^{125}$ or the legal basis for the objection may have been discovered or even created only after the time for objection had passed but before the conviction became final. ${ }^{126}$ Third, the defendant might show cause if the attorney decided not to object because objecting might have had "grisly" results for the defendant, ${ }^{127}$ or because counsel reasonably feared that the trial court or jury might retaliate against the defendant in response to the objection. ${ }^{128}$ Finally, the defendant might also show that no attorney would ever have made a tactical decision to refrain from objecting - that any attorney who had recognized the possibility of an objection would have made one. ${ }^{129}$

\section{B. Actual Prejudice}

A constitutional violation is not in itself proof of actual prejudice; ${ }^{130}$ the defendant must show concrete harm. The habeas

125. Compare United States v. Costello, 221 F.2d 668, 676-77 (2d Cir. 1955) (failure to object until trial that grand jury's indictment based on hearsay excused where defense could not have discovered that information in time to comply with FED. R. CRIM. P. 12), affd on other grounds, 350 U.S. 359 (1956), with United States v. Amaral, 488 F.2d 1148, 1152 (9th Cir. 1973) (motion to suppress untimely under Rule 12 because no reason to believe discovery inadequate to alert defense to government's intended use of evidence). See also Brady v. Maryland, 373 U.S. 83 (1963) (government's failure to disclose co-defendant's confession violates due process).

126. Cf. O'Connor v. Ohio, 385 U.S. 92 (1966) (per curiam) (prospective application of new constitutional command applies to defendant on direct appeal). See also Doby v. Beto, 371 F.2d 111 (5th Gir. 1967); United States v. Rosenson, 291 F. Supp. 867 (E.D. La. 1968), affd per curiam, 417 F.2d 629 (5th Cir. 1969), cert. denied, 397 U.S. 962 (1970). In contrast, there may be no cause if the factual information, rather than the legal support, was discovered or created only after the defendant's conviction if counsel could reasonably have discovered that information earlier. See note 123 supra.

127. Fay v. Noia, 372 U.S. 391,440 (1963) (defendant feared to press state court appeal because at retrial he might be sentenced to death). But of. Bordenkircher v. Hayes, 434 U.S. 357 (1978) (threat of recidivist sentence not enough to overturn guilty plea to lesser charge).

128. See Whitus v. Balkcom, 333 F.2d 496 (5th Cir. 1964) (no deliberate bypass where counsel feared that attack on racial composition of all-white petit jury would inflame jury); $c f$. Estelle v. Williams, 425 U.S. 501, 511 (1976) (no evidence that counsel "feared any adverse consequences attending an objection" to jail clothes).

129. See Gardner v. Florida, 430 U.S. 349, 361 (1977) (no waiver when "no basis for presuming . . . that counsel could possibly have made a tactical decision not to examine" presentence report in capital case, citing Estelle); Jiminez v. Estelle, 557 F.2d 506 (5th Cir. 1977) (cause established if counsel knew facts warranting objection to court's unconstitutional use of prior conviction where failure to object could not be tactically based); Bromwell $\mathrm{v}$. Williams, 445 F. Supp. 106 (D. Md. 1977)(characterizing failure to object to argument on consolidation motion before petit jury as one that could not involve tactical judgment, and contrasting that situation to Estelle where attorney could have made tactical decision concerning client's appearance in jail clothes). In effect Bromwell's and Jiminez's conclusions are a finding of counsel's incompetency for not having objected. They also mark a return to the willingness of courts to infer what counsel intended when no record of his actual intent exists.

130. In Francis, for example, the district court found that the grand jury selection proc- 
court will not presume harm even if the defendant has understandable difficulty in finding the evidence to establish prejudice, ${ }^{131}$ or if the government could have prevented the occurrence of the constitutional violation by policing itself, or if the trial court itself committed the violation. ${ }^{132}$ Beyond this minimum, the Court has left no clear clue about the meaning of actual prejudice. But several sources help reveal the type of petitioner for whom the Court intends to reserve relief.

First, a petitioner will not win relief by establishing only that if defense counsel had objected, either the defense trial strategy ${ }^{133}$ or the evidence presented to the jury would have changed. The Court has already rejected those possibilities as grounds for relief in connection with a motion for new trial under Rule 33 of the Federal Rules of Criminal Procedure, ${ }^{134}$ a motion that presents a more compelling

ess was unconstitutional, but the Supreme Court affirmed the court of appeals' decision to remand the case to decide whether the defendant had been prejudiced by the violation. Francis v. Henderson, 425 U.S. 536, 542 (1976).

131. See United States v. Williams, 544 F.2d 1215, 1218 (4th Cir. 1976) (defendant not entitled to presumption of harm from failure of court to inform him of statute requiring appointment of two attorneys in capital case upon request). But see Bromwell v. Williams, 445 F. Supp. 106, 114 (D. Md. 1977) (prejudice found, apparently without proof by petitioner, because "it is quite possible that [the failure to object to argument on motion to consolidate made before petit jury panel] ... would have contributed to Bromwell's conviction"). Bromwell is probably wrong if petitioner must prove his actual innocence to establish prejudice rather than that the jury might have been influenced by his failure to object. See notes 141-51 infra and accompanying text.

132. The refusal to presume prejudice on collateral attack, see note 195 infra, contrasts sharply with the Supreme Court's willingness to presume prejudice on direct appeal. See Geders v. United States, 425 U.S. 80 (1976) (on direct appeal defendant's conviction reversed-without allegation of prejudice-on ground of trial court's order barring defendant from talking with attorney during recess); Herring v. New York, 422 U.S. 853 (1975) (refusal to let counsel give summation unconstitutional regardless of simplicity of case or of strength of government's evidence).

133. The defendant may also be unable to establish how the defense strategy might have changed had the attorney objected. Without an obligation to consult with the defendant, counsel could always explain that he would have done nothing different. See note 118 supra.

Nor is prejudice probably established by showing that counsel failed to object to evidence "essential" to the government's case, but see Crowell v. Zahradnick, 571 F.2d 1257, 1262 (4th Cir. 1977) (Winter, J., dissenting), because Sykes' admissions were "essential" to his conviction on the evidence introduced by the government in its case-in-chief.

134. See United States v. Agurs, 427 U.S. 97 (1976). The Agurs Court did not want to give the jury another opportunity to "flout" the evidence. Id. at 108 n.15 (quoting Brady v. Maryland, 373 U.S. 83, 90 (1963)). But Congress has not enacted proposed legislation that would have required the habeas petitioner to show both that the principal purpose of the constitutional claim was to protect the reliability of the factfinding process and that "a different result would probably have obtained if such constitutional violation had not occurred." S. 567, 93d Cong., 1st Sess. \& 2(a) (1973). 
case for reversal than a habeas petition, since it is usually made before the conviction becomes final. Second, the Court will probably not use the "plain error" doctrine as a guide to actual prejudice, ${ }^{135}$ even though Justices White and Powell appear ready to do so. ${ }^{136}$ Used to grant relief on direct appeal, ${ }^{137}$ the plain error rule would limit relief to "exceptional circumstances."138 Nonetheless, the flexibility of the plain error rule might make its use in the habeas context result in grants of habeas relief more often than the Court intends. ${ }^{139}$

In Estelle, Francis, and Sykes the Court did not discuss the relationship between Rule 33 and habeas prejudice because those cases involved state convictions. But Rule 33's test for grant of a new trial motion may help identify the meaning of prejudice for habeas purposes. Because a motion for new trial must be made quickly (usually within 2 years of verdict if based on newly discovered evidence; within 7 days if based on other grounds), and therefore at a time when the government would not be greatly prejudiced if the conviction is set aside, one anticipates that the defendant must prove greater harm to warrant habeas relief than to get a new trial. Rule 33 provides for grant of a new trial "in the interest of justice": If the motion is based on misconduct by counsel, the government, or the court, Rule 33's test usually requires more than "harmless error"; if based on newly discovered evidence, the test requires, among other things, that the new evidence would probably have resulted in acquittal. See 2 C. Wright, Federal Practice and Procedure $§ \S 551,557$ (1969). If the Court intends that habeas relief should be given more grudgingly than a new trial, it may require the petitioner to show that, but for counsel's failure to object, he could have proved his factual innocence. See notes 141-51 infra and accompanying text.

135. The "cause shown" test of Rule $12(\mathrm{f})$, used to excuse the failure to object, is a disguised form of the "plain error" doctrine. See 8 MOORE, supra note 105, 1 12.03[3]. Thus, if Rule 12 supplies the definition of "actual prejudice," the Court might use the "plain error" doctrine. By so doing, the Court would confirm the suspicion that it has eliminated any difference between the relief available on direct appeal and relief available on collateral attack. See note 53 supra. But see Government of Virgin Islands v. Parrott, 551 F.2d 553, 555 n.3 (3d Cir. 1977) (no "necessary congruence" between plain error and Estelle's waiver test).

136. See Wainwright v. Sykes, 433 U.S. 72, 99 (1977) (White, J., concurring) (habeas petitioner meets burden by showing "plain error"); Estelle v. Williams, 425 U.S. $501,514 \mathrm{n} .2$ (1976) (Powell, J., concurring) ("discretion might sometimes be exercised to overturn a conviction on the familiar principles of plain error").

137. See United States v. Indiviglio, 352 F.2d 276 (2d Cir. 1965), cert. denied, 383 U.S. 907 (1966).

138. United States v. Atkinson, 297 U.S. 157, 160 (1936).

139. Courts sometimes reverse on the basis of "plain error," for example, without proof of the effect of that error on the reliability of the verdict, as long as that error was so obvious that the trial court should have intervened. See id. But the Supreme Court's restriction of habeas relief seems designed to free the habeas court of having to determine the merits of the claim or of criticizing the trial court's failure to act unless the defendant can identify how his attorney's failure actually harmed him. In contrast, appellate courts finding plain error commonly presume harm. See King v. United States, 372 F.2d 383, 395 (D.C. Cir. 1967); 8B MOORE, supra note 105, \52.03[1], at 52-6 to -10. Moreover, a court may reverse for "plain error" when the error involves the "fairness and integrity" of the judicial proceedings, even if the guilty verdict appears reliable. $3 \mathrm{C}$. WRIGHT, supra note $134, \S 856$, at 374 . The Sykes Court, on the other hand, rejecting the use of a presumption to infer the existence of harm, was more interested in the reliability of the verdict than the appearance of fairness in the proceedings. See Wainwright v. Sykes, 433 U.S. 72, 91 (1977).

The Court may be correct in rejecting the plain error rule for federal habeas corpus. 
As a result, to prove actual prejudice, a petitioner probably will have to demonstrate that the verdict was factually inaccurate. This criterion may be expressed in two ways. The first would be a new version of the harmless error rule: The defendant would now have to prove that the alleged constitutional violation was not harmless. ${ }^{140}$ The second, which probably captures more accurately the Court's expectation for a habeas petition, is that the defendant must prove his or her factual innocence and that counsel's failure to object prevented demonstration of that innocence. ${ }^{141}$ To limit habeas relief to the factually innocent defendant is consistent with the Court's re$\operatorname{turn}^{142}$ to an emphasis on fundamental fairness as the test for any

The rule is the epitome of equitable discretion; courts have found grave difficulty in giving it content and have applied it almost viscerally. $3 \mathrm{C}$. WRIGHT, supra note $134, \S 856$, at 373.

140. Normally the state has the burden of proving harmlessness to preserve a conviction. See Chapman v. California, 386 U.S. 18 (1967). Both Estelle and Sykes suggest a shift in the burden, since both found harmless error even though the Fifth Circuit had held that the state could prove the harmlessness of neither the jail clothes in Estelle nor the defendant's statements in Sykes. See notes 45 \& 92 supra and accompanying text.

Significantly, then Assistant Attorney General Rehnquist testified before a congressional subcommittee that one way to limit federal habeas relief was "by a significant broadening of the harmless error rule." Rehnguist Testimony, supra note 24, at 112; of. LiPuma v. Commissioner, Dept. of Corrections, 560 F.2d 84 (2d Cir.), cert. denied, 434 U.S. 861 (1977) (district court erred in saying it could not conclude "beyond a reasonable doubt" that defense motion would have failed and that there was a "reasonable possibility of prejudice to petitioner").

141. This test of factual innocence is not explicitly mentioned in Estelle, Francis, or Sykes, but it is the core of the Court's decision in Stone v. Powell, 428 U.S. 465, 491 n.31 (1976) (habeas review not available for fourth amendment claim adjudicated in state court; exclusionary rule does not go to innocence or guilt) and its more recent decision in Ballew v. Georgia, $98 \mathrm{~S}$. Ct. 1029 (1978). In deciding that 5-person juries in criminal cases were unconstitutional, the Ballew Court discussed the risks of convicting an innocent defendant as the size of the jury decreased, and of acquitting a guilty person as the size of the jury increased. Id. at 1036-38. Compare Gilmore v. Utah, 429 U.S. 1012, 1013 n.1 (1976) (Burger, C.J., concurring) (no relief where defendant did not claim to be innocent), with Chambers v. Mississippi, 410 U.S. 284 (1973) (relief where defendant did assert innocence). See also Friendly, supra note 14, at 160; Shapiro, Federal Habeas Corpus: A Study in Massachusetts, 87 HARv. L. REV. 321, 360 (1973). Judge Friendly's test for habeas relief-a "colorable claim of innocence," Friendly, supra note 14, at 160, understates the proof he would require of petitioner; by acknowledging that in 11 years as a judge he had seen only about six cases where he doubted petitioner's guilt, Judge Friendly implicitly admitted that he would limit relief to the most clearly innocent defendants. See id. at 160 n.94.

But such a test would break markedly from earlier decisions in which the Court considered "innocence" irrelevant in deciding whether habeas relief should be afforded. See Humphrey v. Smith, 336 U.S. 695, 696 (1949); Moore v. Dempsey, 261 U.S. 86, 87-88 (1923) ("[W] hat we have to deal with is not the petitioners' innocence or guilt, but solely the question whether their constitutional rights have been preserved.") (Holmes, J.). For a broad discussion of "factual innocence" and habeas, see Cover \& Aleinikoff, Dialectical Federalism: Habeas Corpus and the Court, 86 YALE L.J. 1035, 1077-100 (1977).

142. There have also been several recent legislative attempts to limit federal habeas relief to the factually innocent petitioner. See, e.g., S. 567, 93d Cong., 1st Sess., 119 Cong. 
constitutional violation, ${ }^{143}$ with its decisions that restrict habeas relief when the defendant has pleaded guilty, ${ }^{144}$ with its refusal to apply prophylactic rules that are designed to control government behavior, ${ }^{145}$ and with its consideration of prospective application for new constitutional pronouncements. ${ }^{146}$

REC. 2221 (1973); note 24 supra. For a discussion of other bills, see Note, supra note 24, at 1221; Note, Relieving the Habeas Corpus Burden: A Jurisdictional Remedy, 63 IowA L. REv. 392 (1977).

These attempts have so far failed. For example, S. 567 died in committee without a hearing. See Friendly, Averting the Flood by Lessening the Flow, 59 CoRnell L. Rev. 634, 637 (1974). One could argue that Congress' refusal to enact any legislative restriction on federal habeas is an implicit statement of congressional intent to keep federal habeas jurisdiction consistent with Fay and with 28 U.S.C. § 2254 (1970). See comment by Senator Nelson on behalf of himself and Senator Mathias accompanying introduction of S. 1314, 123 CoNG. REc. S. 6029, S. 6031 (daily ed., Apr. 20, 1977) (S. 1314 is designed to overrule Francis and Stone). On this analysis, Estelle, Francis, and Sykes are inconsistent with Congress' intent, a possibility that the Court did not discuss in those cases. Cf. Wainwright v. Sykes, 433 U.S. 72, 106 \& n.7 (1977) (Brennan, J., dissenting) (arguing that Congress has power to structure federal habeas jurisdiction and has chosen to require broad federal habeas corpus). Nevertheless, the proposed legislation may influence the Court in deciding how to define actual prejudice. Then Assistant Attorney General Rehnquist, in testimony before a congressional committee, urged Congress to restrict federal habeas jurisdiction by requiring either that the habeas petitioner make a "colorable showing of innocence," or show substantial prejudice. Rehnquist Testimony, supra note 24, at 112 . Justice Rehnquist took the "colorable showing" test from Friendly, supra note 14, at 160 . Judge Friendly would interpret his own test to give relief only to the petitioner of whose factual innocence the habeas court was relatively certain. See note 141 supra.

143. See Manson v. Brathwaite, 432 U.S. 98 (1977); United States v. Washington, 431 U.S. 181 (1977).

144. Because the defendant's admission of factual guilt bars collateral attack on any constitutional issue that does not affect the reliability of the guilty plea or liability for punishment where factual guilt is established, see Menna v. New York, 423 U.S. 61,62 n.2 (1975) (per curiam), the guilty plea cases support the interpretation that habeas relief is now available only to the factually innocent petitioner. See Lefkowitz v. Newsome, 420 U.S. 283, 299 (1975) (White, J., dissenting) (because guilty plea "conclusively" establishes factual guilt, no federal interest in habeas review of matters affecting that issue). The significance of an admission of guilt was not immediately clear from McMann v. Richardson, 397 U.S. 759 (1970), where collateral review was barred with respect to the admissibility of the defendant's confession but not to counsel's competency in advising the defendant on his decision to plead guilty. The MCMann Court could have used a waiver analysis, since counsel had discussed challenging the confession with his client before he pleaded guilty. In Tollett v. Henderson, 411 U.S. 258 (1973), however, collateral review of an attack on the grand jury selection process was also barred even though counsel had not discussed that challenge with his client and may not have recognized that he could have objected. The Tollett Court indicated that the waiver analysis was inapplicable where the defendant had pleaded guilty. Id. at 266.

145. See note 211 infra. Certain Justices have invited the states to enact their own prophylactic rules, but do not intend to impose such rules on the states. See Manson v. Brathwaite, 432 U.S. 98, 118 (1977) (Stevens, J., concurring) (suggesting states adopt procedures to protect against eyewitness misidentification).

146. In deciding whether to apply a constitutional innovation retroactively, the Warren Court analyzed the purpose of that innovation, the extent to which law enforcement authorities had relied on the superseded procedure, and the potential impact on the administration 
The Court may not go so far as to condition habeas relief on proof of factual innocence beyond a reasonable doubt. ${ }^{147}$ The Court may recognize that no federal habeas court, especially one that does not have a complete record of the evidence, can accurately assess the truth of the verdict. ${ }^{148}$ The Court may also decide that federal habeas courts must retain a limited form of general equity jurisdiction to prevent a "miscarriage of justice,"149 apart from questions of strict factual innocence. ${ }^{150}$ But the Court clearly intends that the

of justice of retroactive application. See Stovall v. Denno, 388 U.S. 293, 297 (1967). If the purpose of the new command was to "enhance the reliability of the factinding process at trial," Johnson v. New Jersey, 384 U.S. 719, 728-29 (1966), the Court was more likely to apply that command retroactively.

In urging Congress to enact legislation to restrict federal habeas review of constitutional issues not germane to the reliability of the verdict, the Department of Justice has used the retroactivity decision to support its position. See Letter from Attorney General Richard Kleindienst to Rep. Emanuel Celler, June 21, 1972, reprinted in 119 CoNG. REC. 2222, 2224 (daily ed. Jan. 26, 1973) [hereinafter cited as Kleindienst Letter].

147. Although the Court should define "actual prejudice" as precisely as possible, it might nonetheless authorize the habeas court to reverse as a prophylactic measure in any case of unfairness or government misconduct. For example, Justice Rehnquist, in his testimony as an Assistant Attorney General, suggested habeas relief if "the type of trial to which [the petitioner] was subjected was grossly unfair," Rehnquist Testimony, supra note 24 , at 100, a standard he would reserve for "actually coerced confessions, mob domination of juries, failure to appoint counsel, and other claims of that magnitude." Id. at 102. The Department of Justice later acknowledged that federal habeas should be available for claims involving the "very integrity" of the factfinding process, including the rights to counsel and confrontation and the government's use of perjured testimony. See Kleindienst Letter, supra note 146, at 2225. H.R. 13,772, 92d Cong., 2d Sess. (1972), which the Department of Justice supported, differed from the previously proposed bill H.R. 11,441, 92d Cong., 1st Sess. (1971), that would have permitted habeas relief only if the constitutional violation was not harmless and there existed a substantial doubt about petitioner's guilt. H.R. 13,772 focused more on the "basic fairness" of the adjudication of guilt than on petitioner's guilt or innocence, as H.R. 11,441 did. Kleindienst Letter, supra note 146, at 2225.

148. In another context the Court recently conceded that a determination of innocence-and, thus, conversely, of guilt-is not necessarily factually accurate. See United States v. Scott, 98 S. Ct. 2187, 2197 n.11 (1978) (dismissal of count on ground of pretrial delay not a determination of factual innocence triggering double jeopardy protection).

To require the defendant to prove his factual innocence would also present the habeas court with a difficult problem of deciding what evidence it should consider. What if, for example, evidence had been excluded or not offered at trial that the defendant (or, conversely, the prosecution) claimed, on habeas review, was relevant to his innocence? While a habeas court usually refuses to decide whether there is sufficient evidence to justify the jury's verdict, see Clarke v. Huff, 119 F.2d 204 (D.C. Cir. 1941), will the habeas court not face such questions in evaluating whether the defendant was factually innocent?

149. Wainwright v. Sykes, 433 U.S. 72, 91 (1977). The question, of course, is whether a "miscarriage of justice" occurs only if an innocent defendant is convicted because of counsel's failure, or whether that term also includes misconduct by the government or court.

150. Cf. Gardner v. Florida, 430 U.S. 349 (1977) (reversal for resentencing, even without defense objection, where trial court used confidential presentence report, undisclosed to defendant's counsel or to reviewing court upon appeal, in sentencing defendant to death). 
defendant make "some showing"151 of innocence, and expects federal habeas courts to treat petitions skeptically.

A "factual innocence" standard of "actual prejudice," especially in conjunction with the new restrictive rule of Stone $v$. Powell, ${ }^{152}$ will eliminate from habeas review certain types of constitutional attack that the defendant could have made under Fay because their violation would not threaten the reliability of a jury verdict. The following motions or objections would disappear from habeas review: any attack on the institution of criminal proceedings, ${ }^{153}$ other than a claim of double jeopardy or some other challenge to the trial court's jurisdiction; ${ }^{154}$ certain rights granted by statute; ${ }^{155}$ a due process Rochin v. Califormia-type ${ }^{156}$ challenge to the government's conduct; right-to-counsel questions arising under Massiah v. United States; ${ }^{157}$ the

The significance of Gardner is clouded, however, because the Court assumed that the state courts had reached the issue despite counsel's failure to object, thus authorizing federal habeas review under Brown v. Allen. Id. at 361.

151. See Wainwright v. Sykes, 433 U.S. 72, 84 (1977).

152. Stone barred federal habeas review of a fourth amendment question decided by the state court, review that Brown v. Allen would normally have authorized. See Stone v. Powell, 428 U.S. 465, 522-29 (1976) (Brennan, J., dissenting); notes 246-59 infra and accompanying text.

153. In Francis, the court of appeals suggested that actual prejudice might exist if a grand jury apparently discriminated against co-suspects of different races by indicting one but not the other on identical evidence. Newman v. Henderson, 496 F.2d 896 (5th Cir. 1974). In its reversal, the Francis Court did not comment on that example, an example that would have nothing to do with the reliability of the petit jury's verdict. Cf. Castaneda v. Partida, 430 U.S. 482, 508 n.1 (1977) (Powell, J., dissenting) (suggesting that Stone v. Powell might bar federal habeas review of a grand jury objection decided by state court). Even if federal habeas review of a grand jury issue remains available, the petitioner may be unable to get the proof necessary to establish that prejudice. See note 79 supra.

154. See cases cited in note 101 supra. While these issues do not relate to factual innocence, the Court seems willing to address them on collateral attack.

155. While 28 U.S.C. $\S \S 2254$ and 2255 (1970) provide habeas relief if the petitioner is in custody in violation of federal laws, certain statutory protections have nothing to do with innocence. Cf. United States v. Williams, 544 F.2d 1215, 1218 (4th Cir. 1976) (on direct appeal defendant not entitled to presumption of harm where statutory right to appointment of two attorneys violated).

156. Rochin v. California, 342 U.S. 165 (1952) (police use of stomach pump to seize contraband "shocked conscience" and violated due process). Protection afforded by any prophylactic rule would presumably disappear on collateral review, unless the Sykes Court intended, by its term "miscarriage of justice," 433 U.S. at 91, to authorize relief whenever outrageous conduct contributed to the defendant's conviction, whether committed by the government or others, see note 147 supra, or whenever the punishment was extreme, see note 127 supra.

157. 377 U.S. 201 (1964) (government agent's questioning of defendant without counsel present violated right to counsel). While such violations would probably produce reliable evidence, but of. Brewer v. Williams, 430 U.S. 387, 426 n.8 (1977) (Burger, C.J., dissenting) (noting there was no indication that Massiah's statements were reliable), they nonetheless might remain open for federal habeas as part of the right to counsel. 
right to a jury trial; ${ }^{158}$ a violation of Rule 11 of the Federal Rules of Criminal Procedure; ${ }^{159}$ discriminatory prosecution; ${ }^{160}$ any alleged violation of the exclusionary rule, ${ }^{161}$ including Mapp v. Ohio, ${ }^{162}$ Miranda v. Arizona ${ }^{163}$ or Wade v. United States issues; ${ }^{164}$ and probably erroneous or incomplete jury instructions. ${ }^{165}$

Certain objections or motions ${ }^{166}$ do concern the reliability of the factfinding process and may therefore survive the "factual innocence" test of actual prejudice: a due process attack on an identification procedure; ${ }^{167}$ an involuntary confession; ${ }^{168}$ prejudicial joinder; ${ }^{169}$ the right to a speedy trial where the defense has lost a crucial witness; ${ }^{170}$ the defendant's appearance in jail clothes before the jury or inflammatory pretrial publicity; ${ }^{171}$ the use of perjured testimony; ${ }^{172}$

158. See Kleindienst Letter, supra note 146, at 2225.

159. Id. But of. Note, Rule II and Collateral Altack on Guilly Pleas, 86 YALE L.J. 1395 (1977) (arguing that evidentiary hearings necessary to resolve petitioner's attack on guilty plea). Denial of collateral review of Rule 11 issues would apply only to federal prisoners under 28 U.S.C. \$ 2255 (1970).

160. See generally People v. MacFarland, 540 P.2d 1073 (Colo. 1975).

161. A principal purpose of the proposed legislative restrictions on federal habeas has been to eliminate review of exclusionary rule issues. See Kleindienst Letter, supra note 146, at 2225.

162. 367 U.S. 643 (1961) (fourth amendment).

163. 384 U.S. 436 (1966) (police interrogation).

164. 388 U.S. 218 (1967) (lineup).

165. While refusing to give or misstating instructions on the presumption of innocence or reasonable doubt may violate due process, see Taylor v. Kentucky, 98 S. Ct. 1930 (1978); Dunn v. Perrin, 570 F.2d 21 (1st Cir. 1978), habeas challenges to other instructions, either given over objection or not given when requested, are unlikely to warrant relief. See Lakeside v. Oregon, 98 S. Ct. 1091 (1978) (no due process violation to instruct, over defendant's objection, on defendant's failure to testify); Henderson v. Kibbe, 431 U.S. 145 (1977) (failure to give causation instruction not reversible error) (Court did not discuss whether habeas review should have been barred by counsel's failure to object, a ground on which Chief Justice Burger would have denied review, $i d$. at 157); $c$. Cupp v. Naughten, 414 U.S. 141 (1973) (failure to instruct or instruction given must violate constitution and not simply be universally condemned to warrant reversal).

166. An interesting question is whether collateral relief would remain for defenses like insanity, self-defense, and entrapment, which excuse the defendant from responsibility for his actions.

167. See Manson v. Brathwaite, 432 U.S. 98 (1977).

168. See Kleindienst Letter, supra note 146, at 2225.

169. If counsel fails to object, however, the client gets relief only if the trial court should have intervened. See Cupo v. United States, 359 F.2d 990, 993-94 (D.C. Cir. 1966). In contrast, if counsel objected, prejudice is presumed if joinder was improper. See Ward v. United States, 289 F.2d 877 (D.C. Cir. 1961).

170. But of. United States v. Lovasco, 431 U.S. 783 (1977) (delay in indictment not necessarily ground for dismissal even though defendant lost important witness).

171. See Kleindienst Letter, supra note 146, at 2225. Either might undercut the jury's ability to fairly assess the evidence at the trial.

172. See Napue v. Illinois, 360 U.S. 264 (1959); Kleindienst Letter, supra note 146, at 2225. 
or a confrontation clause issue. ${ }^{173}$ Additionally, the defendant could show actual prejudice if, but for the constitutional violation, he might have been convicted of a lesser charge ${ }^{174}$ or if he might have been sentenced to a lesser punishment. ${ }^{175}$

Nevertheless, that a constitutional right is not automatically excluded from habeas review under the "factual innocence" test of actual prejudice does not mean that its violation will necessarily result in relief. ${ }^{176}$ The defendant must show not just that the alleged violation usually threatens the reliability of the factfinding process, but also how that violation undercut the reliability of the verdict in his or her particular case. ${ }^{177}$ Federal habeas courts probably will separate the challenged evidence from the remainder of the record to evaluate the likelihood that an innocent defendant was convicted. Thus, if the only evidence that the government introduced was allegedly tainted, the habeas court might grant relief. ${ }^{178}$ But if other evidence, whether direct or circumstantial, was sufficient to support the conviction, the habeas court would deny relief. ${ }^{179}$

\section{The Defendant's Burden of Proof Under "Cause and Prejudice"}

Under Fay v. Noia, though the defendant may have had the burden of going forward with the production of evidence to prove that no deliberate bypass had occurred, ${ }^{180}$ the state probably had the bur-

173. Cf. Chambers v. Mississippi, 410 U.S. 284 (1973) (defendant stressed his innocence in trying to challenge nonparty's repudiation of own confession to crime).

174. See Williams v. Estelle, 500 F.2d 206 (5th Cir. 1974), affd on other grounds, 425 U.S. 501 (1976).

175. See Jiminez v. Estelle, 557 F.2d 506 (5th Cir. 1977) (trial court used unobjected to, unconstitutional prior conviction in sentencing); Kleindienst Letter, supra note 146, at 2225; of. Humphrey v. Cady, 405 U.S. 504 (1972) (remand to determine if petitioner deliberately bypassed opportunity to object to continuation of commitment).

176. For one thing, if the habeas petitioner does not recognize his burden or artfully tailor his allegations, the habeas court will probably deny relief without requiring the state to respond.

177. For a comparison of the virtues of a categorical, as opposed to those of a case-bycase, analysis of actual prejudice under the "factual innocence" classification, see Cover \& Aleinikoff, supra note 141 , at 1088-91.

178. See Friendly, supra note 14, at 163-64.

179. Analyzing whether the defendant suffered actual prejudice caused by a constitutional violation thus differs from deciding whether the violation occurred in the first place. Cf. Manson v. Brathwaite, 432 U.S. 98, 118 (1977) (Stevens, J., concurring) (noting that in deciding whether pretrial identification procedure was constitutional, court should not consider other evidence of guilt).

180. This was, however, one of the many unsettled questions under Fay. Under FED. R. CRIM. P. 12 the defendant must show cause to excuse the failure to objecț. See United States v. Freeling, 31 F.R.D. 540 (S.D.N.Y. 1962). 
den of persuasion. ${ }^{181}$ Since the Johnson $v$. Zerbst waiver doctrine relied on by Fay prohibited judicial presumption of a waiver from a silent record, ${ }^{182}$ the defendant could satisfy the burden of going forward simply by denying bypass. The state then had to demonstrate that the defense had in fact deliberately bypassed the opportunity to object. $^{183}$ Under this rule the government in some cases had developed evidence that the attorney had in fact committed a deliberate bypass, ${ }^{184}$ and in other cases had convinced the habeas court that it could infer from the record a deliberate bypass because the failure to object was consistent with the defense's trial strategy. ${ }^{185}$ But the government's burden often caused it to choose not to oppose a habeas petition on the ground of deliberate bypass. ${ }^{186}$ Moreover, the defendant under $F a y$ probably had the burden of establishing only a prima facie case that a constitutional violation had occurred. If the defendant did that, the burden passed to the government to prove that no constitutional violation had occurred, or that the violation was harmless error. ${ }^{187}$

But the Supreme Court has now made clear that the defendant carries the burden of persuasion on both cause for and actual prejudice resulting from the failure to object. ${ }^{188}$ The decisions of the court of appeals and the Supreme Court in Sykes illustrate this shift in the defendant's burden of proof. The court of appeals refused to

181. See United States ex rel. Schaedel v. Follette, 275 F. Supp. 548 (S.D.N.Y. 1967).

182. See Fay v. Noia, 372 U.S. 391, 439 (1963) (citing Johnson v. Zerbst, 304 U.S. 458, 464 (1938)).

183. See United States ex rel. Schaedel v. Follette, 275 F. Supp. 548, 554 (S.D.N.Y. 1967); Wright \& Sofaer, Federal Habeas Corpus for State Prisoners: The Allocation of Fact-Finding Responsibility, 75 Yale L.J. 895, 967 (1966). But see Nash v. United States, 342 F.2d 366 (5th Cir. 1965) (defendant has burden to prove no deliberate bypass because judgment carries presumption of correctness).

184. The attorney-client privilege did not bar testimony by the attorney about his purpose in not objecting. See Henderson v. Heinze, 349 F.2d 67 (9th Cir. 1965).

185. See cases cited in notes $15-16$ supra.

186. See, e.g., Williams v. Beto, 364 F. Supp. 335 (S.D. Tex. 1973), rev'd on other grounds, 500 F.2d 206 (5th Cir. 1974), rev'd, 425 U.S. 501 (1976).

187. See Partida v. Castaneda, 524 F.2d 481 (5th Gir. 1976) (government had burden to rebut defendant's prima facie showing of discrimination in grand jury selection; prejudice not discussed), affd, 430 U.S. 482 (1977). But of. Bruce v. Estelle, 536 F.2d 1051, 1058-59 (5th Cir. 1976) (defendant had burden to prove by preponderance of evidence that he was incompetent to stand trial; greater burden might present due process issue).

188. The tests are independent, and proof of actual prejudice is not enough without proof that excuses the failure to object. See Jiminez v. Estelle, 557 F.2d 506 (5th Cir. 1977) (defendant actually prejudiced because given greater sentence through use of prior conviction; remand to determine whether cause existed). But see Arnold v. Wainwright, 516 F.2d 964, 968-69 (5th Cir. 1975) (refusing to decide whether tests are independent because defendant established neither). 
infer that the attorney had made a deliberate decision not to object, because it could detect no tactical reason why counsel had failed to object to the introduction of the defendant's statement into evidence. ${ }^{189}$ Rejecting this approach, the Supreme Court noted that the defendant had not proved the impossibility that the failure to object at the trial level was a tactical choice. ${ }^{190}$

Under the new test, the burden is on the defendant to establish "cause" to excuse the failure to object. To place that burden on the defendant means that the federal habeas court is no longer required to review the trial record to determine whether the attorney deliberately bypassed the opportunity to object when counsel has not explained the failure to object in testimony or affidavit. The defendant must now establish why the attorney did not object; it is insufficient to indicate that defense counsel failed to consult with the defendant or that the defendant did not agree with counsel's apparent decision not to object. Nor is it enough for the defendant to aver that the failure to object constituted ineffective representation. ${ }^{191}$ Counsel's incompetency might constitute cause, but that allegation, standing alone, is not enough. ${ }^{192}$

189. Wainwright v. Sykes, 528 F.2d 522, 528 (5th Cir. 1976). The court of appeals did not cite either Johnson or Fay, but its conclusion was clearly based on those two cases.

190. Wainwright v. Sykes, 433 U.S. 72, 91 (1977).

191. See Lumpkin v. Ricketts, 551 F.2d 680, 682-83 (5th Cir. 1977) (if assertion of ineffective representation established cause, that test would be eliminated; but no explanation of how petitioner proves cause).

192. In determining whether counsel's failure to object constituted ineffective representation, courts must decide whether to focus solely on the significance of that failure, or to assess that failure as one part of counsel's overall performance. Compare McMann v. Richardson, 397 U.S. 759 (1970) (suggesting focus on particular action), with Cooper v. Fitzharris, 551 F.2d 1162 (9th Gir. 1977), rehearing en bane ordered, Sept. 22, 1977 (focus on counsel's overall competence), and Williams v. State, 477 S.W.2d 24 (Tex. Crim. App. 1972) (counsel's overall performance competent; trial not a farce or mockery).

In saddling the defendant with the burden of showing cause, the Court did not discuss, and perhaps failed to appreciate, the problems that the defendant will face in determining why counsel did not object. If defense attorneys are not required to consult with their clients, and if they can make all strategic decisions for their clients, see notes 50 \& 118 supra, then defendants may not learn of their attorneys' failure to object until long after convictions become final. Defendants may have grave difficulty learning why their attorneys refrained from objecting: Lawyers rarely document their reasons for not doing things. Even those attorneys who recognized the possibility of objecting and had reasons for not doing so may well forget those reasons during the interval between trial and federal habeas petition. Further, as in Francis where trial counsel became ill, see text accompanying note 63 supra, the attorney may be unavailable to testify at a habeas hearing. Finally, some attorneys may fabricate tactical justifications for their past failures out of fear for their professional reputations. Cf. United States ex rel. Johnson v. Johnson, 531 F.2d 169, 175-76 \& n.17 (3d Cir. 1976), cert. denied, 425 U.S. 997 (1977) (counsel who could have been unaware that government could not ordinarily use defendant's prior convictions to impeach explained his failure to put client on stand by claiming defendant would have put own character in issue and 
Finally, in addition to proving cause, the defendant also bears the burden of proving "prejudice." The Court in Sykes expressly refused to follow the court of appeals in presuming prejudice as a result of the introduction of the defendant's statement. ${ }^{193}$ Even under the new test, a defendant who has established a prima facie case still will be entitled to a presumption that a constitutional violation occurred. ${ }^{194}$ But the defendant will not be entitled to a presumption that the violation caused prejudice to the defense. ${ }^{195}$

The new habeas cases therefore place a dramatically higher evidentiary burden on a defendant who fails to raise a claim at trial than the one borne by a defendant who does object at trial or who has the merits of his or her claim decided in the state courts. ${ }^{196}$

thereby rendered prior convictions admissible); Johns v. Perini, 462 F.2d 1308, 1313 (6th Cir. 1972) (counsel deemed understandably defensive about reputation). Counsel's admission of a failure to do something could provide prima facie proof of civil malpractice, although the failure might not even have damaged the client if, for example, the defendant is reconvicted at retrial.

For a thorough discussion of the effect of the new habeas decisions on the attorney-client relationship, see Part IV infra.

193. Compare 433 U.S. at 91 , with 528 F.2d at 526-27.

194. Cf. Peters v. Kiff, 407 U.S. 493 (1972) (white defendant challenging racial bias in jury selection stated due process objection sufficient for factfinding remand).

195. See Davis v. United States, 411 U.S. 233, 245 (1973). The petitioner must prove actual prejudice, because he is not entitled to the presumption of innocence after his conviction becomes final. See Bounds v. Smith, 430 U.S. 817, 840 (1977) (Rehnquist, J., dissenting); Ross v. Moffitt, 417 U.S. 600, 610-11 (1974).

Eliminating a presumption of prejudice where the defense did not object will eliminate habeas relief for many defendants. Compare Geders v. United States, 425 U.S. 80 (1976) (conviction reversed on direct appeal even though defendant failed to show how judge's order that defendant not consult with counsel prejudiced defense), with United States v. Williams, 544 F.2d 1215 (4th Cir. 1976) (defendant with single lawyer not entitled to irrebuttable presumption of prejudice on basis of statute giving right to representation by two attorneys in capital cases).

196. For an illustration of this difference, see Castaneda v. Partida, 430 U.S. 482 (1977). Petitioner, whose untimely motion had been decided on the merits by the Texas appellate court, used statistical evidence to establish a prima facie case of discrimination in grand jury selection. That prima facie proof shifted the burden to the state, a burden it had not met. The court of appeals remanded to the district court to reverse the conviction or for further fact findings, see id. at 509, a remand affirmed by the Supreme Court, id. at 501. If the district court concluded that the state had not met its burden, it should reverse the conviction. In contrast, if the state courts had not decided the merits, the defendant would have had to prove both cause and actual prejudice, burdens he almost certainly could not have carried.

A further example of this remarkable difference emerges in a comparison of Francis and its companion case in the Fifth Circuit, Newman v. Henderson, 496 F.2d 896 (5th Cir. 1974). As in Francis, the defendant in Newman had failed to make a timely objection to the grand jury, but a state appellate court denied Newman's attack on the merits. Id. at 897 . In both cases, the federal district court on habeas review had reversed after finding jury discrimination. The Fifth Circuit remanded Newman with directions to dismiss, but remanded Francis 


\section{The Ironic Harvest of "Gause and Prejudice"}

\section{Justice Rehnquist's opinion in Wainzeright $v$. Sykes contains the} Court's general justification for what Justice Rehnquist admits to be the substantial restriction the new habeas cases place on the access to federal collateral review achieved by Fay v. Noia. ${ }^{197}$ Without adverting at all to the traditional arguments proffered in favor of liberal habeas review, ${ }^{198}$ and without offering any substantial empirical or precedential basis for his own arguments, Justice Rehnquist offers several specific judicial goals which he claims will be better served by the cause and prejudice test than by the Fay bypass test. Those goals appear to converge into a general asserted interest in encouraging the resolution of constitutional claims in the state courts as a means of ending litigation and reducing the workload of the federal habeas courts. ${ }^{199}$

to permit a determination of whether the facts constituted a showing of prejudice. Id. at 899 . The Supreme Court affirmed Francis, 425 U.S. 536 (1976), but remanded Newman for further consideration, Newman v. Henderson, 425 U.S. 967 (1976). Upon remand of Newman, the court of appeals affirmed the district court's reversal because the defense had made an unrebutted prima facie showing of discrimination. Because the state court had reached the merits, the court of appeals thought that it could also do so, in effect overruling its earlier decision that had conditioned habeas review on a showing of cause and prejudice. Newman v. Henderson, 539 F.2d 502 (5th Cir. 1976).

197. See 433 U.S. at 87 . In justifying the new restrictions on federal habeas, Justice Rehnquist did not reinterpret Fay's own historical analysis of the scope of the habeas writ, see Fay v. Noia, 372 U.S. 391, 399-426 (1963). He did note the shifts in the Court's interpretation of the scope of the writ, but did not criticize those shifts. See 433 U.S. at 77-84. Justice Powell, who concurred in Sykes, challenged Fay's historical analysis in Schneckloth v. Bustamonte, 412 U.S. 218, 250, 252-56 (1973) (Powell, J., concurring). Compare Oaks, Legal History in the High Court-Habeas Corpus, 64 Mrch. L. REv. 451 (criticizing Fay's history), with Tushnet, supra note 102, at 487 (criticizing Justice Powell's history). The dispute over whose view of history is revisionist illustrates that the focus should be on the competing interests in the habeas question, unless Congress decides to enact new legislation.

198. Four basic reasons may be given to justify liberal habeas review. First, habeas review acts as a substitute for direct appeal to the Supreme Court, because the Court accepts direct appeals so infrequently. See Haynsworth, supra note 14, at 601; Note, supra note 24, at 1224 n.19 (reviewing the number of appeals the Court hears). Second, Fay in effect guaranteed review by one federal court of federal constitutional issues. See Amsterdam, Search, Seizure and Section 2255: A Comment, 112 U. PA. L. REV. 378, 380 (1964). Third, state courts will not faithfully enforce federal constitutional law because local pressures force them to concentrate on the question of guilt or innocence. See Brown v. Allen, 344 U.S. 443, 510-11 (1953) (Frankfurter, J., separate opinion); Developments in the Law-Federal Habeas Corpus, 83 HARv. L. REv. 1038, 1060-66 (1970). But see Stone v. Powell, 428 U.S. 465, 493-94 n.35 (1976) (disagreeing with this fear). Finally, federal habeas review will promote the uniform application of federal constitutional law. See Note, supra note 24, at 1226 \& n.28 (citing authorities).

199. The Court's habeas decisions must be read along with its decisions limiting the power of the federal courts to interfere with continuing state criminal and civil proceedings. In Younger v. Harris, 401 U.S. 37 (1971), the Court developed fully its concern for comity and federalism and its belief that state courts will properly interpret and enforce the Federal 
This part first analyzes the validity of this interest in finality, questioning its empirical and jurisprudential foundation. It then proceeds to examine a striking irony of the new decisions: that by directing its attack on Fay rather than Brown v. Allen, the Court may have achieved the worst of two worlds. It has denied future petitioners any forum for a constitutional claim unraised at trial, while potentially exacerbating the very friction between state and federal courts which the cause and prejudice test was designed in part to relieve.

\section{A. The Finality Interest}

\section{The interest defined.}

The new cause and prejudice test greatly enhances the power of the states-previously denied them by Fay-to prevent federal habeas relief for defendants by enforcing procedural waiver rules against claims not raised at trial. Justice Rehnquist closed his majority opinion in Sykes by elaborating a number of justifications which he hopes will result from this new restriction: (1) It increases the chances of a state court hearing on the constitutional claim if the defense objects, and so may provide future federal habeas courts with a more complete and accurate record for their decisions; ${ }^{200}$ (2) it may obviate a few federal habeas petitions, since some defendants will actually win their claims if they raise them at trial, and thereby either gain acquittal or at least eliminate the claim from later review; ${ }^{201}$ (3) it may prevent attorneys from cynically "sandbagging"--deliberately withholding an objection and gambling that if the defendant is not acquitted at trial he could win reversal by raising the claim on federal habeas review; ${ }^{202}$ (4) it will encourage the states to enforce their procedural forfeiture rules; ${ }^{203}$ and (5) it will

Constitution. Younger has been much criticized. See Redish, The Doctrine of Younger $v$. Harris: Deference in Search of a Rationale, 63 CORNELL L. REV. 463 (1978) (criticizing Younger and citing other negative commentary). The Court's interest is understandable: All participants-the defendant, counsel, the government, the trial court, and the federal habeas court-would be served if the state trial court decided the issue. Witnesses are more likely to remember the relevant facts, the trial court can better assess their credibility, and the habeas court will have a more complete record if it must review the state court's decision. The question remains, however, whether the defendant should be effectively stripped of habeas review if counsel does not object, as Estelle, Francis, and Sykes portend.

200. 433 U.S. at 88. Justice Rehnquist apparently assumes that defense counsel will object more frequently after having read Francis and Sykes, a questionable assumption.

201. Id. at 88-89.

202. Id. at 89.

203. Id. at 90 . 
enhance respect for the state trial as the "main event" rather than a "tryout" before ultimate federal disposition. ${ }^{204}$

Though Justice Rehnquist offered little or no support for the proposition that these judicial goals required a severe retrenching of $F_{a y},{ }^{205}$ the general interest in finality and judicial efficiency into which these goals converge seems superficially plausible. Federal habeas courts have faced difficult and burdensome work in interpreting issues that defendants appear to raise, or in determining whether deliberate bypass has occurred, or in deciding whether to require the state to respond to the petition and to hold a federal habeas hearing. ${ }^{206}$ Aided by an attorney or a clever "jail-house lawyer," the de-

204. As Justice Brennan himself noted in dissent, see 433 U.S. at 115, Justice Rehnquist omitted perhaps the most compelling reason for restricting habeas review: the government's difficulty in gathering evidence to rebut the petitioner's prima facie case and in retrying the petitioner after a reversal of conviction. Cf. Browder v. Director, Dep't of Corrections, 434 U.S. 257 (1978) (rejecting state's petition for reconsideration of habeas relief as untimely after delay caused by difficulty in locating police officers who had arrested petitioner and could testify as to probable cause).

In his concurring opinion in Sykes, Chief Justice Burger offered an additional, and indirectly related, justification: that the new rule would prevent disruption of trials caused by unnecessary consultations between attorney and client. See 433 U.S. at 92-94 (Burger, C.J., concurring). The Chief Justice sought to restrict the Fay bypass standard to those decisions which only defendants themselves could make-such as the decision of the defendant in Fay not to appeal, see note $\mathbf{5 0}$ supra.

The Chief Justice expressed concern that if Fay applied to the myriad tactical decisions an attorney must make during trial, judges would have to permit intolerable interruptions in trials to assure that the defendants knowingly and intelligently approved every decision of counsel. 433 U.S. at 93 (Burger, C.J., concurring). He therefore saw the cause and prejudice test as a means of reducing trial disruption by keeping responsibility for most tactical decisions on counsel. The Chief Justice's concern may be correct if applied to those evidentiary objections which counsel could not anticipate; the attorney cannot be expected to confer with the defendant about the form of every prosecution question or the answer given by every witness. Even Justice Brennan agreed that counsel could bind the client in situations where the client's participation was not feasible. 433 U.S. at 116 (Brennan, J., dissenting). Although the Chief Justice thought that Justice Brennan's concession on this point was an "extraordinary modification" of Fay, 433 U.S. at 94 (Burger, C.J., concurring), Justice Brennan had probably already modified his Fay position in Henry v. Mississippi, 379 U.S. 443, 451-52 (1965). But the Chief Justice's concern is invalid with respect to most constitutional objections. Any attorney who plans the defense should be able to anticipate possible constitutional objections, especially since such procedural rules as FED. R. CRIM. P. 12 already force attorneys to plan objections in advance or lose the right to direct appeal of a claim.

205. The fact that the Court has frequently changed its position on the availability of habeas review, as Justice Rehnquist pointed out, 433 U.S. at 81 , certainly does not in itself justify rejecting the clear holding of the Warren Court that providing a federal forum was more important than ending litigation by legal fiction in the name of judicial efficiency, Fay v. Noia, 372 U.S. 391, 438-39 (1963); cf. Kaufman v. United States, 394 U.S. 217, 226 (1969) (mechanism for relief necessary to protect constitutional rights relating to the criminal trial process).

206. The sequential obligations of the federal district courts are outlined in RULES Governing Section 2254 CaSes, 28 U.S.C.A. foll. § 2254 (1977). 
fendant can frequently devise constitutional attacks on his conviction even years after it has become final. ${ }^{207}$ Perhaps most compelling is the argument that allowing collateral review of claims unraised at trial deprives the federal courts of a record of the evidence relevant to deciding the merits of the claims. ${ }^{208}$

Moreover, Justice Rehnquist's tip of the balancing scales in favor of ending litigation over providing a federal forum finds some precedential support within the Burger Court's own interpretation of certain Warren Court decisions as creating remedial devices to police government conduct rather than actual substantive rights. ${ }^{209}$ Since the Burger Court has not extended those remedies to new factual situations, ${ }^{210}$ the Court may not believe it necessary to provide habeas review to ensure that the states properly apply these remedies. ${ }^{211}$

\section{The interest scrutinized.}

Nevertheless, for several reasons, this interest in finality is a highly suspect justification for the grave retrenchment of federal habeas relief effected by the cause and prejudice rule. First, the empirical data that exist on the subject of the federal courts' habeas workload suggest that Justice Rehnquist's implied assertion of the need for reduction of that workload may be greatly exaggerated. ${ }^{212}$ Second, as

The Court may be especially concerned about the time required to process habeas petitions. See note 223 infra. See generally Shapiro, supra note 141; Note, supra note 142.

207. This fear may be overstated, since the defendant cannot relitigate an already rejected claim simply by altering the facts and allegations. See Cunningham v. Estelle, 536 F.2d 82 (5th Cir. 1976) (no review of counsel's competency because petitioner had unsuccessfully raised that issue earlier).

208. If the state courts develop a record of the relevant evidence, the district court may not need to conduct its own factfinding hearing. See Townsend v. Sain, 372 U.S. 293 (1963) (explaining when habeas court must hold evidentiary hearing); of. O'Berry v. Wainwright, 546 F.2d 1204 (5th Cir.), cert. denied, 433 U.S. 911 (1977) (sufficient information developed at trial to decide merits of fourth amendment issue not raised at trial).

209. See, e.g., Michigan v. Tucker, 417 U.S. 433 (1974) (interpreting Mirande warnings as prophylactic safeguards).

210. See, e.g., Kirby v. Illinois, 406 U.S. 682 (1972) (refusing to apply United States v. Wade, 388 U.S. 218 (1967) (excluding identifications where counsel was not present at lineup) to preindictment lineups).

211. The present Court has generally been critical of prophylactic remedies. See, e.g., Rizzo v. Goode, 423 U.S. 362, 377-80 (1976) (denying injunction against city officials to force more thorough review of police conduct; federalism should restrict use of federal equity power to create prophylactic procedures to control misconduct by a few state employees); Cover \& Aleinikoff, supra note 141, at 1084-85 \& nn. 226-27; of. United States v. Janis, 428 U.S. 433, 446-54 (1976) (questioning deterrent value of fourth amendment's exclusionary rule).

212. Justice Rehnquist cited no statistics concerning the numbers of habeas petitions. In 1976, 9254 habeas petitions were filed in the federal district courts by state and federal 
Justice Brennan argued, the Court's implicit balance of the need to limit access to a federal forum to achieve finality and efficiency against the interest of defendants in having constitutional claims adjudicated may violate a deliberate congressional balance in favor of the latter. ${ }^{213}$ Third, as Justice Brennan also noted, invoking the finality interest where an attorney may have inadvertently neglected to raise a constitutional claim at trial irrationally penalizes hapless defendants in hopes of deterring the negligence of counsel. ${ }^{214}$

But perhaps the most serious flaw in Justice Rehnquist's invocation of the finality justification for the cause and prejudice test lies in his faulty assumptions about the motives and abilities of defense trial attorneys, assumptions underscored by the specific rationale that the new test would prevent attorneys from "sandbagging" in state trials. Comparison with the Fay Court's notions about defense attorneys helps reveal the fragility of these assumptions.

defendants. The numbers have decreased since 1970 , the high point, during which 10,613 petitions were filed. See 1976 ANNuAl RePORT OF THE DiRector of The ADMINISTRATIVE Office OF THE UNITEd STATES CoURTS 94. The Henry Court was certainly aware of the work involved with habeas petitions. Henry v. Mississippi, 379 U.S. 443, 452-53 \& n.8 (1965). Despite the work involved, however, the question remains whether Congress and not the Court should decide where scarce judicial resources should be directed, see Stone v. Powell, 428 U.S. 465, 525-26 (1976) (Brennan, J., dissenting), although that question of course begs the other question of Congress' actual intent in enacting 28 U.S.C. $\$ \S 2241-2255$ (1970).

That few habeas petitions are granted suggests that reviewing the flood of petitions is not worth the effort; on the other hand, because relief is granted so rarely, the argument that federal habeas review interferes too much with state interests is probably exaggerated. The type of relief granted is also a significant consideration-in few cases is the petitioner actually released from custody. See Brown v. Allen, 344 U.S. 443, 498 (Frankfurter, J.) (separate opinion) (in 4-year period only five petitioners released).

213. See 433 U.S. at 106-07 \& n.7 (Brennan, J., dissenting) (Congress chose to provide a federal forum for preserving federal rights by authorizing litigation of constitutional claims in federal district court). In neither Estelle, Francis, or Sykes did the Court face the question of how Congress wanted the federal habeas courts to treat procedural defaults by state defendants. Only in Davis v. United States, 411 U.S. 233 (1973), did the Burger Court face this question, where the issue was whether a federally convicted defendant, having failed to challenge the grand jury selection process before trial in violation of FED. R. CRIM. P. 12, could receive collateral review of that issue absent a deliberate bypass. The Court thought not to give collateral relief to such a defendant was inconsistent with Rule 12(f)'s test that the defendant show "cause" to excuse noncompliance with the Rule in order to warrant direct review of the issue. See notes 68-70 supra and accompanying text. There was, however, no legislative history to clarify congressional intent on this issue. Later, in Francis, the Court held that "comity" required extending the Davis interpretation of congressional "intent" to cover state defendants who violated state procedural rules. See notes 76-79 supra and accompanying text.

214. 433 U.S. at 113-14 (Brennan, J., dissenting). 


\section{The Sykes Court's misconception of defense counsel.}

As it did in Davis, ${ }^{215}$ the Court in Sykes assessed both the attorney's motives in not objecting and the attorney's ability to recognize the need to object differently from the Fay Court. One could argue that Fay was designed to force the attorney to consult with his client. At a time when an attorney's representation was constitutionally ineffective only if it sunk to the level of a "farce" or a "mockery of justice,"216 Fay could also be viewed as a way to reach constitutional issues that the attorney had ignorantly or mistakenly failed to raise when that failure did not equal ineffective representation. ${ }^{217} \mathrm{Fay}$ indirectly protected the defendant against his attorney's incompetency, although the Henry Court did limit Fay when it acknowledged that the attorney could make certain tactical decisions without consulting his client. ${ }^{218}$ But Henry nonetheless seemed to expect that the attorney would make a decision that was intended to achieve some tactical advantage for the defendant at the trial. ${ }^{219}$ And Henry did require the attorney's decision to have been competent. ${ }^{220}$

The Sykes Court had a different explanation for the attorney's failure to object. Without citing any examples to justify his factual assumption, Justice Rehnquist suggested that the Fay deliberate bypass test encouraged attorneys not to object in the trial court in order to preserve what they hoped would become a winning issue on federal habeas review. The attorney would thus "sandbag" the state trial and federal habeas courts, ${ }^{221}$ because, if the defendant was con-

215. Davis v. United States, 411 U.S. 233, 241 (1973).

216. These were the tests generally used at the time of Fay and Heny. See, e.g., Frand v. United States, 301 F.2d 102, 103 (10th Cir. 1962) ("farce"); Edwards v. United States, 256 F.2d 707, 708 (D.C. Cir.), cert. denied, 358 U.S. 847 (1958) ("mockery of justice"). Most courts today ask whether counsel was reasonably competent. See note 300 infra and accompanying text.

217. Cf. Meador, The Impact of Federal Habeas Corpus on State Trial Procedures, 52 VA. L. REV. 286, 290-91 (1966) (Fay could also reflect lack of confidence in state judges' handling of constitutional issues).

218. Henry v. Mississippi, 379 U.S. 443, 451-52 (1965). To harmonize Henry with Fay, one could interpret Henry to bar federal habeas relief only if the defendant himself waived the opportunity to object, but to bar state post-conviction review and direct review by the Supreme Court if counsel waived that opportunity. Henyy, of course, did not clearly make this distinction. See note 10 supra.

219. 379 U.S. at 450,451 . This expectation underlies the Henry Court's belief that application of the waiver doctrine (i.e., a deliberate decision by counsel) will usually produce the same results as application of the state's procedural bar. Id at 448 n.3.

220. Id. at 450; see Fay v. Noia, 372 U.S. 391, 439 (1963).

221. 433 U.S. at 89. Compare ABA POST-CONVICTION REMEDIES, supra note $19, \S 6.1$, at 89 (agreeing that defense might withhold claims until collateral attack), with Friendly, supra note 14, at 158 (expressing disbelief that defense would knowingly do so). Judicial 
victed at trial, he could still have his conviction reversed on federal habeas review. As in Francis, this argument has force if the objection is to the institution of the charges against the defendant. But Justice Rehnquist's cynical assumption that defense attorneys cunningly attempt to build, or fail to correct, error in a case makes little sense whenever the objection involves evidence that the government could use at trial. ${ }^{222}$ To pin one's hopes on a successful habeas petition, given the time necessary to get that review, ${ }^{223}$ the defendant's problems in developing the record on habeas review, ${ }^{224}$ and the unlikelihood of success, ${ }^{225}$ is a decision so questionable as to raise an issue of the attorney's competency. It is also difficult to believe that an attorney would knowingly forego any opportunity to end the pro-

suspicion of habeas petitioners is widespread. See Bonds v. Wainwright, 564 F.2d 1125, 1134 n.4 (5th Cir. 1977) (Tjoflat, J., dissenting) (arguing that prisoner chose not to appeal and delayed collateral attack until he thought state no longer had trial transcript and thus could not retry him).

222. That sort of decision by counsel also invites judicial discipline. Cf. McAlaney v. United States, 539 F.2d 282 (1st Cir. 1976) (failure to accurately represent plea bargaining to client calls attorney's fitness into question); McQueen v. Swenson, 498 F.2d 207, 218 n.15 (8th Cir. 1974) (indicating that counsel would be subject to disciplinary proceedings if he deliberately provided ineffective assistance in order to upset the judicial process); ABA CODE OF Professional ResPonsiBILITY, Disciplinary Rule 7-101 (1976). Because it should also bar federal habeas as a deliberate bypass under Fay, of. Murch v. Mottram, 409 U.S. 41 (1972) (per curiam) (where counsel failed to present all known constitutional issues in state postconviction proceeding, as required by state law, federal habeas is barred as to claims not presented), one suspects that the Sykes Court was more interested in limiting relief to petitioners than in eliminating abuses by counsel.

An issue other than grand jury selection that might involve sandbagging is double jeopardy; an attorney might delay an objection until after jeopardy had attached in the hope of precluding retrial. Cf. Sanabria v. United States, 98 S. Ct. 2170, 2176 (1978) (counsel justified failure to object until close of government's case on ground that objection had not "ripened" until that point); Serfass v. United States, 420 U.S. 377, 394 (1975) (noting, without deciding, question of effect of defense's decision not to object until jeopardy attached).

223. The time spent in adjudicating a habeas petition is sometimes enormous. Consider the 13-year saga of one petitioner whose attorneys had not subpoenaed four witnesses: State v. Garton, 371 S.W.2d 283 (Mo. 1963) (denial of direct appeal); State v. Garton, 396 S.W.2d 581 (Mo. 1965) (denial of state collateral attack); Garton v. Swenson, 266 F. Supp. 726 (W.D. Mo. 1967) (federal habeas remand to state courts for hearing); Garton v. State, 454 S.W.2d 522 (Mo. 1970) (denial of relief on remand); Garton v. Swenson, 367 F. Supp. 1355 (W.D. Mo. 1973) (federal habeas denied without hearing); Garton v. Swenson, 497 F.2d 1137 (8th Cir. 1974) (remand to district court to hold evidentiary hearing on question of effectiveness of counsel); Garton v. Swenson, 417 F. Supp. 697 (W.D. Mo. 1976) (relief granted).

224. Initially, the defendant must allege facts which, if true, would warrant relief. See Pierce v. Cardwell, 572 F.2d 1339 (9th Cir. 1978). But to develop his allegations factually, he cannot use the discovery methods of the Federal Rules of Civil Procedure unless, and "to the extent that, the judge in the exercise of his discretion and for good cause shown grants leave to do so, but not otherwise." Rules Governing SECTION 2254 CASES, 28 U.S.C.A. foll. $\$ 2254$ (1977), Rule 6(a).

225. See Shapiro, supra note 141 , at $339-42$ (denial rate is about $96 \%$ ). 
ceedings in favor of his client or, at least, to disrupt the government's case. Most attorneys would think it wise to object even if they did not want to suppress all of the evidence that the objection would cover, or if they thought that the government could use the evidence in spite of a successful objection. ${ }^{226}$ If the objection is granted, the defense attorney controls whether that evidence is admitted. Counsel might alter his attack on the government's evidence, or decide not to present certain defense evidence if he is no longer worried about countering the excluded evidence, or even decide to introduce the evidence himself, or to permit the government to use it. Whatever his decision, however, he may have succeeded in disrupting the government's case.

Sykes itself is an example. ${ }^{227}$ Sykes testified at his trial to establish that he had been drinking and that he had killed in self-defense. He was impeached, however, by his statements to the police because he had not mentioned certain points to them that he added in his testimony to support his claim of self-defense. ${ }^{228}$ If the government

226. Concurring in Sykes, Justice Stevens speculated that trial counsel might have decided not to object because he recognized that the government could use the defendant's statement, even if suppressed, to impeach his trial testimony. Wainwright v. Sykes, 433 U.S. 72, 96-97 (1977) (Stevens, J., concurring). Such a decision would make no sense if the government could not carry its burden of proof without the defendant's statement-an assessment of the Sykes evidence that is difficult to make. Even in Sykes, however, an objection would have preserved the record in case a state appellate court later decided that the state constitution precluded impeachment use of statements taken in violation of Miranda. See People v. Disbrow, 16 Cal. 3d 101, 545 P.2d 272, 127 Cal. Rptr. 360 (1976) (state constitution forbids use of statement obtained in violation of Miranda for impeachment purposes). Also, defense counsel might prefer to suppress the statement and then to have the defendant attempt to explain during direct examination any inconsistencies between his or her testimony and statements to the police.

227. Sykes also suggests other reasons for counsel to object and to demand a hearing. Defense counsel sometimes want a hearing, even with no chance to prevail on the motion, in order to get a client to realize that he or she cannot be acquitted at trial and should realistically accept a plea bargain offered by the government. For example, Sykes rejected a government offer to plead guilty to a felony less serious than the one he was convicted of and to receive a sentence of 1 year in the county jail. Sykes wanted a jury trial because he learned a short time before his trial that a jury had acquitted Angela Davis, charged in California with aiding an alleged escape attempt in a highly charged political case. Interview with trial counsel (Mar. 15, 1978). Had there been a hearing on the admissibility of his statements, Sykes might have recognized the folly of rejecting the plea offer and the risk he ran in going to trial. Convicted, Sykes was sentenced to 10 years in prison. If the defendant still wants a trial, counsel may nonetheless have developed information at that hearing to use to impeach government witnesses who testify at trial.

228. In his testimony Sykes apparently added that the victim, one Willie Gilbert, had threatened him before leaving Sykes' trailer home, and that after leaving Gilbert had aggres- 
had not introduced Sykes' statement in its case-in-chief, the defense attorney might have decided not to have Sykes testify. There were no eyewitnesses to the killing. Several witnesses testified that Sykes appeared drunk. ${ }^{229}$ There was fairly strong evidence to support a self-defense theory without Sykes' testimony. ${ }^{230}$ The defense attorney could, as a result, have decided not to have Sykes testify, reasoning that the cost of impeachment outweighed whatever Sykes could have added, in terms of information or credibility, to the self-defense theory. ${ }^{231}$

Justice Rehnquist thus erroneously assumed that a defense attorney generally elects not to object. ${ }^{232}$ In fact, counsel's failure is usually the result of his inattention, his ignorance of either the applicable law or the facts of his client's case, or his inability to appreciate the tactical value or constitutional worth of an objection.

sively turned back toward Sykes with what Sykes thought was a weapon. Interview with trial counsel (Mar. 15, 1978). When Sykes spoke with the police, he apparently first claimed that Gilbert had shot himself, and then that he had shot Gilbert when Gilbert "patted his butt" at Sykes. Brief for the United States as Amicus Curiae to Supreme Court of the United States at 51, Wainwright v. Sykes, 433 U.S. 72 (1977).

229. Wainwright v. Sykes, 528 F.2d 522, 524 n.4 (5th Gir. 1976). The police testified that they would have arrested Sykes for drunkenness had they not arrested him for homicide. Brief for the Respondent in the Supreme Court of the United States at 5, Wainwright v. Sykes, 433 U.S. 72 (1977).

230. According to trial counsel, Mrs. Sykes testified that her husband and Gilbert had fought over the shotgun - the murder weapon-before Gilbert left the trailer, that Gilbert had said as he left that he was going to get a gun, that Gilbert had cut Sykes' hand with a knife, and that she had been terrified. Interview with trial counsel (Mar. 15, 1978). Additionally, several defense witnesses testified that Gilbert carried a shotgun and had threatened them at various times. Brief for the United States as Amicus Curiae to Supreme Court of the United States at 9. The trial court refused the defense request to instruct the jury that it could consider the victim's character for violence as evidence that he had attacked first or had provoked Sykes because Sykes did not know of that character. Interview with trial counsel (Mar. 15, 1978).

231. Of course, defense counsel might have decided that the jury would accept a selfdefense theory only if Sykes testified. But that judgment, assuming that counsel made it, is now beyond evaluation. Additionally, had Sykes not testified, the government probably would have had to introduce ballistics and fingerprint testimony to establish that Sykes' shotgun was the murder weapon. (Also, in some jurisdictions Sykes' inebriation would itself have provided a defense of diminished responsibility.) Finally, Sykes was also impeached with prior convictions-for aggravated assault with a pistol and for illegal possession of a firearm-another reason to have kept him from testifying. Brief for the United States as Amicus Curiae to Supreme Court of the United States at 9.

232. The Henry Court seemed to make the same mistake in assuming that the result on habeas would not differ whether the procedural bar or the waiver doctrine was applied. Henry v. Mississippi, 379 U.S. 443, 448 n.3 (1965). See Hill, supra note 10, at 997. 


\section{B. Reaffirming Brown While Restricting Fay: The Worst of Both Worlds}

\section{1. "Double-or-nothing" habeas review.}

In Brown v. Allen, decided in 1953, the Supreme Court authorized the federal habeas courts to reconsider the merits of any constitutional issue of criminal procedure decided by a state court. ${ }^{233}$ The Burger Court restricted the Brown principle somewhat in Stone v. Powell, ${ }^{234}$ which barred federal reconsideration of fourth amendment claims by state defendants. But Justice Rehnquist's opinion in Sykes, though its careful language did not foreclose future limitation of Brown v. Allen, implicitly reaffirmed the Brown holding. ${ }^{235}$ The Court may therefore appear to have left at least one liberal avenue open to federal habeas petitioners who raise other than fourth amendment claims. But the Burger Court's decision in Estelle, Francis, and Sykes to restrict the scope of Fay instead of Brown has ironic consequences that may unnecessarily injure criminal defendants while undermining one of its main goals.

Even granted the validity of its judicial goals, the Sykes Court may have chosen the wrong device to implement them. Under the new controlling law of federal habeas corpus-the nexus of Brown and Sykes-the federal habeas courts cannot address the merits of almost any constitutional claim which a defendant fails to raise at trial unless the defendant can achieve the difficult feat of proving cause and prejudice or the state courts choose to ignore their own procedural forfeiture rules and decide the merits of the claim themselves. A defendant who now complies with the state's procedural rules gets review of constitutional claims in both the state and federal habeas courts. The defendant who fails to comply with the state procedural rules gets review in neither. ${ }^{236}$

233. 344 U.S. 443,458 (1953). To date, the sole exception to the Brown rule is that established for fourth amendment questions by Stone v. Powell, 428 U.S. 465 (1976). After Brown, the federal habeas courts can treat the issues resolved and the record developed by the state courts according to procedures announced in Townsend v. Sain, 372 U.S. 293 (1963), and 28 U.S.C. $\S 2254$ (1970).

234. 428 U.S. 465 (1976).

235. See 433 U.S. at 87 ("This rule of Brown v. Allen is in no way changed by our holding today."); of. id. at 80,81 (reserving question of extending the limited deference to state decisions established by Brown).

236. The Court will almost certainly create a similar dichotomy in the direct and collateral review available for the federally convicted defendant who petitions for collateral relief under 28 U.S.C. $\$ 2255$ (1970) by applying the Sykes test to the federal defendant who fails to comply with the timing requirements for objections of FED. R. CRIM. P. 12. In Davis v. United States, 411 U.S. 233 (1973), the Court took the first step toward this result by inter- 
If the state courts are as interested as the Supreme Court thinks they are in ending litigation, many may read Sykes as an invitation to end the apparently growing trend of the state courts to reach the merits of claims unraised at trial: ${ }^{237}$ The states may begin enforcing their procedural bars more strictly, ${ }^{238}$ or may enact contemporaneous objection rules where such rules do not already exist, or strain in their own post-conviction review to avoid any mention of constitutional claims not raised at trial. ${ }^{239}$ Some states may even consider repeal-

preting the "cause shown" restriction of Rule 12(f) to bar collateral relief for a late challenge to a grand jury selection process. See notes 68-70 supra and accompanying text. Because Congress, after Davis, amended Rule 12(b) (2) to bar review of any motion or objection that could have been made pretrial, it may have sub silentio adopted the Davis Court's interpretation of Rule 12's bar. (At issue in Davis was whether Rule 12's bar applied to collateral as well as to direct attack; the Rule is silent on that point.) Congress' and the Court's work with Rule 12 suggests that the Court is moving to eliminate any distinction between the relief available on direct and collateral attack for at least the federally convicted defendant.

237. See, e.g., Castaneda v. Partida, 430 U.S. 482, 485, 489 (1977) (state appellate court reached merits on constitutional claim first raised by defendant on motion for new trial after conviction). See also Shapiro, supra note 141, at 369 .

238. Justice Rehnquist suggested that the state courts have been reaching the merits of even those issues deemed forfeited: The states have assumed under Fay that the federal habeas courts will decide those issues notwithstanding the state procedural bar, and at least wish to have their own views on the merits considered by the federal courts. Wainwright v. Sykes, 433 U.S. 72, 89-90 (1977); see Shapiro, supra note 141, at 348 . Justice Rehnquist cited no examples to support his suggestion, and Sykes and Francis both belie his concern, since in neither case did the state court decide the merits of the claim. Nor did Justice Rehnquist identify the harm that would result if state courts did reach the merits. His argument appears inconsistent with the Stone Court's assumption that state courts will protect federal constitutional rights as faithfully as would the federal habeas courts. Stone v. Powell, 428 U.S. 465, 493-94 n.35 (1976).

239. Identifying the basis of a state appellate court's denial of relief-on the merits or through enforcement of a procedural bar-will become a difficult and tension-producing process. State courts that enforce a procedural bar may justifiably fear that any comment about the constitutional issues presented by the defendant on appeal will be interpreted by $a$ federal habeas court, upset about the procedural bar and eager to remedy a perceived wrong, as a decision on the merits. See Irwin v. Dowd, 359 U.S. 394 (1959); Hart, supra note 54, at 110 (criticizing Irwin Court's conclusion that state courts had decided merits); of. United States ex rel. Harding v. Marks, 541 F.2d 402, 407 (3d Cir. 1976) (Hunter, J., dissenting) (court of appeals reached merits of jury instruction issue that counsel had not raised at trial where state courts denied relief without opinion; because issue fundamental, state court's decision held to have been on merits). In contrast, some habeas courts may strain to conclude that the state did not decide the federal constitutional issue. Cf. Taylor v. Kentucky, $98 \mathrm{~S}$. Ct. 1930, 1933 n.10 (1978) (holding that state court had reached merits of federal constitutional issue, after several Justices during oral argument questioned whether state courts had done so; oral argument reported at 23 CRIM. L. REP. (BNA) 4006-07 (1978)). In light of Inwin and Taylor, state courts will craft their opinions to indicate whether they are reaching the merits of the federal constitutional issue. But state courts cannot block federal habeas by refusing to address federal constitutional issues fairly raised by the defendant. Cf. Smith v. Dagnon, 434 U.S. 332 (1978) (per curiam) (habeas court cannot deny habeas petition by relying on failure of state court to mention constitutional issue in its opinion). As a result, federal habeas courts will be burdened with reviewing the petitioner's and the government's 
ing their statutory authorization of appellate review of constitutional issues litigated before the defendant pleads guilty if that review would authorize federal habeas review. ${ }^{240}$

This new "double-or-nothing" rule for access to federal habeas review might be justified if it helped fulfill the Burger Court's implicit goal of reducing the strain in the relationship between the state and federal courts. But the decision to reaffirm Brown while restricting Fay may actually exacerbate that strain. Federal reversal of a state court's decision on the merits of a constitutional issue-a reversal which in effect tells a state court that its constitutional analysis is faulty-may irritate the state court more than a reversal on a constitutional issue that the state for procedural reasons chose to ignore. ${ }^{241}$ Moreover, the state court and the federal habeas court may enter a tense struggle over whether the state court in fact reached the merits and thereby invited habeas review under Brown. ${ }^{242}$

If the Supreme Court sincerely wants constitutional claims to be settled once and for all in the state courts, it may have pressured the state courts in precisely the wrong way. State trial courts will now be reluctant to intervene to protect a defendant who has not objected at trial, and state appellate courts will be reluctant to consider on appeal any federal constitutional issue raised there for the first time. ${ }^{243}$

\section{Limiting Brown: a missed opportunity or the lesser of two evils?}

If the Supreme Court wants to encourage the state courts to protect the defendant's constitutional rights and thereby reduce the workload of the federal habeas courts and federal intrusion into state affairs, ${ }^{244}$ one wonders why it ignored its opportunity to restrict the

briefs in the state litigation to determine whether petitioner complied with the state's procedural rule in raising federal constitutional issues presented on habeas.

240. Cf. Lefkowitz v. Newsome, 420 U.S. 283 (1975) (federal habeas available where state permits review of suppression motion after guilty plea).

241. While no surveys have sought the reaction of state court judges, this hypothesis seems reasonable, since Brown apparently generates more habeas litigation than does Fay. See Shapiro, supra note 141, at 369-70; of. Friendly, supra note 14, at 169 n.139 (similar evaluation of federal reversals of state courts on Miranda grounds).

242. See note 239 supra and accompanying text.

243. The Court may feel that these pressures on the state courts will indirectly serve to encourage defendants to raise their claims at trial, but, as noted above, this belief is based on an extremely unrealistic assessment of the motives and abilities of state trial lawyers. See notes 221-32 supra and accompanying text.

244. If due process does not require the states to create a post-conviction, collateral review process, of. Case v. Nebraska, 381 U.S. 336 (1965) (per curiam) (issue of whether state must provide collateral review of federal constitutional issues moot where state adopted such 
scope of the Brown 0 . Allen principle instead of the Fay principle. This is not to suggest that limiting Brown is a just solution to the problems of federal habeas corpus jurisdiction. ${ }^{245}$ But examining this potential alternative to Estelle, Francis, and Sykes helps to demonstrate the unfortunate and ironic consequences of the "cause and prejudice" test. It also suggests what the Court may yet have in store for the Brown principle.

Stone v. Powell virtually eliminated-federal relitigation of fourth amendment issues, but also laid the groundwork for an even broader limitation on Brown. The defendants in Stone, unlike those in Estelle, Francis, and Sykes, had raised their federal constitutional claims at trial. Both the state trial and appellate courts had decided the fourth amendment motions to suppress-erroneously, according to the federal courts of appeal-on collateral review. Despite Brown, however, the Supreme Court forbade federal habeas review of those state court decisions. ${ }^{246}$

Writing for the majority in Stone, Justice Powell compared the costs and benefits of habeas review of a fourth amendment issue, ${ }^{247}$ using the same sort of analysis that the Court undertook in Sykes. Because evidence seized illegally is ordinarily reliable, the Stone Court thought that the government's use of that evidence would not jeopardize the accuracy of the guilt-determination process. ${ }^{248}$ Nor did the fourth amendment itself require that a federal habeas court review the constitutionality of the challenged search or seizure-the exclusionary rule was viewed as a judicially created remedy for a fourth amendment violation rather than as an independent right. ${ }^{249}$

In Stone the Court did not say that it would extend that decision's restriction on the federal habeas review authorized by Brown to other

procedure after state courts denied review), one would think that the Burger Court would be searching for a carrot to induce state courts to provide post-conviction review of federal constitutional claims.

245. Indeed, some commentators have urged that Brown be overruled. See Bator, Finality in Criminal Law and Federal Habeas Corpus for Slate Prisoners, 76 HARv. L. Rev. 441, 523-28 (1963); Friendly, supra note 14, at 155; Address by the Hon. Paul C. Reardon, President, Nat'I Center for State Courts, at the Annual Dinner of the Section of Judicial Administration, A.B.A., San Francisco (Aug. 14, 1972), quoled in Schneckloth v. Bustamonte, 412 U.S. 218, 263-64 (1973) (Powell, J., concurring). Moreover, the legislative effort to restrict federal habeas jurisdiction has focused on Brown more than on Fay. See S. 567, 93d Cong., 1st Sess. (1973) (no federal habeas review if issue was raised and determined, there was fair and adequate opportunity to have had it raised and determined, or it still could be raised and determined).

246. The chorus criticizing Stone grows. See commentary cited in note 25 supra.

247. 428 U.S. at $489-95$, especially n.31.

248. Id. at 490 .

249. Id. at 486. 
constitutional claims, nor has the Court done so in the two opportunities it has had so far-cases involving alleged violations of Miranda rights $^{250}$ or improper grand jury selection. ${ }^{251}$ But to extend Stone to cases involving grand jury challenges ${ }^{252}$ and the Miranda safeguards, ${ }^{253}$ or to any rights or remedies whose violation does not jeopardize the accuracy of the petit jury's verdict, would be consistent with Stone's emphasis on the question of guilt and innocence, which is also the focus of the guilt-innocence question suggested by the new "actual prejudice standard." Th4 Therefore, if the Court had realized

250. See Brewer v. Williams, 430 U.S. 387 (1977). Brewer involved, among other things, the defendant's alleged waiver of Miranda warnings. The Court affirmed reversal of the state court's decision to admit the defendant's uncounseled statements without discussing whether Stone should bar federal habeas review of the merits. The majority chose not to discuss Stone's applicability despite Chief Justice Burger's ringing dissent in which he urged that Stone should bar relief. Id. at 426-28 (Burger, C.J., dissenting). Justice Powell, who concurred, did not support extending Stone, because the parties had not briefed the issue. Id. at 414 (Powell, J., concurring). But the Court's presentation of Brewer more as a sixth amendment than as a Miranda issue, see id. at 397-98, is not inconsistent with its analysis in Estelle and Sykes: The defendant's decision to forego an attorney, whether the right to counsel comes from the fifth amendment or the sixth, must be analyzed in Johnson v. Zerbst waiver terms and may therefore survive the new restrictions on Fay. See note 54 supra.

251. See Castaneda v. Partida, 430 U.S. 482 (1977). In Castaneda, the Court affirmed the court of appeals' conclusion that the state had not proved that the grand jury that had indicted the defendant had been constitutionally selected. Although the defendant had not complied with the state's procedural rule governing the timing of objections to grand juries, the Texas state courts had ignored that failure and decided the merits of the defendant's claim against him, and so the Court was willing to review the merits. Id. at 485-86 n.4. In reviewing the merits, the majority did not discuss whether Stone should bar collateral review. But in his dissent Justice Powell suggested that Stone be extended to grand jury challenges. Id. at 508 n.1.

252. It is difficult to imagine, for example, how an unconstitutionally selected grand jury would undermine the reliability of the petit jury's verdict. As Justice Powell argued in Castaneda, to bar federal habeas review of a grand jury issue makes even more sense than barring review of a fourth amendment issue, because the former involves no "flaw" in the trial itself. Id. at $508 \mathrm{n.1}$ (Powell, J., dissenting).

253. The Court has held that the Miranda warnings, at least when the issue is not the defendant's waiver of counsel, operate as prophylactic safeguards like the exclusionary rule of the fourth amendment; they do not comprise a right themselves, but deter police violations of the fifth amendment. See Michigan v. Tucker, 417 U.S. 433 (1974).

254. See notes 130-79 supra and accompanying text. A question left open in Stone is whether the defendant, who failed to use the "opportunity" to litigate the fourth amendment issue, might get habeas review by showing cause and actual prejudice. The answer is probably no: While he might show cause, the defendant could probably never show prejudice so long as that test requires proof of factual innocence, because Stone assumed that the challenged evidence would not undermine the reliability of the jury's factfinding. However, because unconstitutionally seized evidence is not always probative, see Tushnet, supra note 102 , at 497-98 (noting Moore v. Illinois, 408 U.S. 786 (1972) (seized shotgun of different gauge from one used in homicide), and Coolidge v. New Hampshire, 403 U.S. 443 (1971) (fabric sweepings from defendant's car)), the government's use of such unchallenged evidence might be so prejudicial as to raise a due process issue that could undercut the accuracy of the jury's ver- 
that approving Brown v. Allen in Sykes might actually exacerbate the federal-state tension it has sought to relieve, the Court might have directed its narrowing attack at Brown rather than Fay by barring habeas review-regardless of whether the state courts had decided the merits - of at least those issues unrelated to the question of guilt. ${ }^{255}$

By embracing another element of the Stone holding, the Sykes Court might have narrowed Brown even further. Stone barred habeas review of fourth amendment issues whenever the state had provided the defendant with "an opportunity for full and fair litigation" of that issue. ${ }^{256}$ Though the standards for such an opportunity remain uncertain, ${ }^{257}$ the Sykes Court might have extended Stone by barring federal collateral review of any issue decided on the merits, so long as the state court had given the defendant sufficient opportunity to argue the claim. ${ }^{258}$ The federal habeas court would then at most

dict. Cf. Moore v. Illinois, 408 U.S. 786, 801 \& n.1 (1972) (Marshall, J., concurring in part and dissenting in part) (troubled by whether introduction of shotgun of different gauge than murder weapon was due process violation).

255. These issues might include "technical" defenses, like double jeopardy (but if based on a state court reversal of conviction for insufficient evidence rather than a procedural violation, the double jeopardy claim is related to guilt-innocence, of. Green v. Massey, $98 \mathrm{~S}$. Ct. 2151 (1978) (jeopardy attaches if state court reversed because evidence insufficient; because basis of reversal unclear, remand to determine basis)), an unconstitutionally selected grand jury or discriminatory prosecution, that would end the proceedings without a jury decision on the merits of guilt-innocence. See Cover \& Aleinikoff, supra note 141, at 1086-100. The issues might also include the use of the exclusionary rule, which, though affecting the evidence considered by the jury, is justified on grounds other than the reliability of the evidence involved. See Richardson v. Stone, 421 F. Supp. 577 (N.D. Gal. 1976) (Stone bars review of Miranda issue litigated in state courts).

Though Justice Brennan strongly dissented in Stone, Stone v. Powell, 428 U.S. 465, 502 (1976) (Brennan, J., dissenting), he cited the Slone holding in Sykes, arguing the negative pregnant that not even a procedural default should bar federal habeas review of a constitutional claim that bore on guilt and innocence. Wainwright v. Sykes, 433 U.S. 72, 110 (1977) (Brennan, J., dissenting).

Congressional attempts to restrict federal habeas have focused on exclusionary rule issues. See Kleindienst Letter, supra note 146, at 2225.

256. 428 U.S. at 494.

257. See note 102 supra.

258. This approach assumes that it is more important to have every constitutional issue decided by at least one court (whether a state court or federal habeas court) than it is to relitigate those issues that the state courts have decided with the hope of increasing through relitigation the possibility of an accurate resolution of the constitutional issue. This approach would make the state court decision final, whereas it is currently only presumed correct, see 28 U.S.C. § 2254(d) (1970), unless the issue involves the fourth amendment, see Stone v. Powell, 428 U.S. 465 (1976). This approach would also eliminate in most cases the need for the federal habeas court to hold an evidentiary hearing. See Townsend v. Sain, 372 U.S. 293 (1963) (listing instances where habeas court should hold evidentiary hearing). Because the habeas court would not redecide the constitutional issue, it would not need to hold a hearing to help it redecide the historical facts or the constitutional significance of those facts. 
review the fairness and thoroughness of the state court process in deciding the merits, rather than reconsider the merits themselves. ${ }^{259}$

Limiting Brown in either of the ways suggested might therefore have created a less restrictive alternative for federal habeas review than limiting Fay. Francis and Sykes rest largely on Justice Rehnquist's highly questionable assumption that defense attorneys intentionally forego the opportunity to object. ${ }^{260}$ But as argued above, many defense attorneys will continue to fail to object, out of negligence or inadvertence, even if they recognize the devastating consequences of such a failure under the new cause and prejudice test. Had the Court chosen to restrict habeas review by limiting the scope of Brown, a state court, aware that its decision on the constitutional issue would be immune from federal habeas review on the merits,

259. In Slone the state courts had decided the fourth amendment issues. But Slone's use of the word "opportunity" suggests that federal habeas might be barred even if the state court did not decide the merits, so long as it gave the defendant a procedurally fair chance to raise the claim. In Gates v. Henderson, 568 F.2d 830 (2d Cir. 1977) (reversing panel's decision), the Second Circuit held that Stone barred habeas review of a fourth amendment issue that the defendant had not raised, and the state courts had not reviewed, because the defense could have objected on that ground at trial. Defense counsel had objected at trial to the police seizure of the disputed evidence, but not on fourth amendment grounds. Id. at 836. The court of appeals reversed a panel's decision that had interpreted Stone as permitting federal habeas review, in the absence of a Fay deliberate bypass, where the state courts had not decided the merits of the claim. Id. at 833. The court thought Slone had overruled Fay at least with respect to fourth amendment issues, and that Stone had also overruled that part of Townsend v. Sain, 372 U.S. 293 (1963), which had ordered a federal habeas court to conduct an evidentiary hearing whenever the state proceedings-through no bypass of the defendant-had failed to develop crucial evidence. Federal habeas review was barred in Gates on the ground that the state had not denied the defense an adequate opportunity to litigate the fourth amendment issue, 568 F.2d at 839, even if the state court did not actually decide the merits of the fourth amendment issue. The court suggested that the state would not provide an "opportunity" to litigate a fourth amendment issue if it prevented the defendant from exploring whether police testimony was perjured, see United States ex rel. Petillo v. New Jersey, 418 F. Supp. 686 (D.N.J. 1976), or if mob domination prevented the defendant from raising the issue, see Frank v. Mangum, 237 U.S. 309 (1915). 568 F.2d at 840.

Gales restricts federal habeas more than did O'Berry v. Wainwright, 546 F.2d 1204 (5th Cir.), cert. denied, 433 U.S. 911 (1977), where the Fifth Circuit had barred habeas review of a fourth amendment issue that counsel had not raised at trial, but where the state appellate courts had a complete record of the facts relevant to that issue even though they denied review of it. Even if Gates' interpretation of Stone's "opportunity" is correct, that interpretation should nevertheless not be extended to eliminate habeas review of other than fourth amendment issues. To extend Stone to bar habeas relief on every federal constitutional issue whenever the defense failed to capitalize on the opportunity to object would effectively eliminate habeas review and would mean that no court would decide the merits of the issue. The restriction of Brown suggested in the text would apply only when the state court actually decided the merits of the constitutional issue, and would restrict habeas review to an evaluation of the procedure whereby the state court had reached that decision.

260. See notes 221-32 supra and accompanying text. 
might be more willing to confront the constitutional claims of criminal defendants.

For example, assuming a limitation on Brozen, the state court might intervene to determine what federal constitutional questions counsel had not raised and why counsel had not done so. That intervention would better protect the defendant against an inept, negligent, disloyal, or unperceptive attorney, and would eliminate the stark difference between the protection afforded a defendant whose counsel raises claims at trial and one whose counsel does not. It would also properly limit enforcement of the state's procedural bar to those cases where both the attorney and defendant agreed not to object and therefore committed a deliberate bypass. Finally, limiting Brown rather than Fay might have eliminated one form of friction caused by Brown-the conclusion by the federal court that the state court had wrongly decided the constitutional issue ${ }^{261}$ - and also reduced the workload of the federal habeas courts as well. ${ }^{262}$

\section{The vices of the lesser of two evils.}

Despite these apparent benefits of limiting Brown, that approach, when compared to the new Sykes rule, has such drawbacks that it may have value chiefly as a hypothesis to illustrate some of the intractable dilemmas of federal habeas corpus and the Burger Court's failure to justly or even rationally deal with them. The first drawback is the uncertainty that state courts, encouraged by a limitation of Brown to play an active role in protecting federal constitutional rights, will actually protect those rights. Freed from federal habeas review, the state courts might respond to local pressure to convict defendants at the expense of vigorous enforcement of federal consti-

261. Any form of federal habeas review will interfere with state interests in some way. Under Stone, for example, the habeas court must determine whether the state's procedure for litigating fourth amendment issues was "full and fair." See Flagg, supra note 25, at 169-70. See also Note, supra note 142, at 422-30 (comparing federal with Iowa state habeas statutes to determine whether latter were equivalent of former). If for a procedure to be "full and fair" the state must create a collateral review process and test the defendant's failure to object by the cause and prejudice standard, but see note 259 supra, Stone would interfere enormously with the interest of the state in creating its own procedure and in ending litigation. Moreover, the new habeas decisions do not permit a state to bar, through its procedural rule, federal habeas review completely, because Francis and Sykes did graft the cause and prejudice test onto state rules in each case.

262. Though there are no statistics to support the assumption, defense attorneys probably object-iand thereby preserve claims for later review-more frequently than they fail to object. If this assumption is correct, the Court could have reduced the federal habeas workload more by restricting Brown than by enforcing state contemporaneous objection rules. Of course, such a restriction might have added to the Court's own docket by increasing certiorari petitions from state denial of the merits of objections. See Tushnet, supra note 102, at 494. 
tutional rights. Whether that result would occur is a question that will continue to divide judges and commentators, ${ }^{263}$ because there is no way to test empirically the state judicial response to any limitation of Brown. ${ }^{264}$

Second, limiting Brown instead of Fay might still, in its own way, increase tensions between the federal and state courts. Under this approach, the federal habeas court would examine the constitutional issue in the one instance where the state had clearly announced that it wanted to end litigation and seal the conviction. Third, although the state courts might still receive "instruction" in the meaning of federal constitutional rights if federal courts continued (perhaps through their supervisory power) to reconsider federal constitutional issues raised by federal defendants on collateral attack, ${ }^{265}$ to limit Brown might also end the fruitful "dialogue" between state and federal courts in interpreting federal constitutional issues that habeas review provides. ${ }^{266}$ Finally, to limit Brown but not Fay would force the federal habeas court to develop a record of the information relevant to the constitutional claim, raised for the first time on collateral attack, without help from the state court that had enforced its procedural bar-a problem that the Sykes Court understandably wanted to avoid.

263. See Flagg, supra note 25, at 162-63 (listing commentators who express distrust of state courts). Compare Brown v. Allen, 344 U.S. 443, 511 (1953) (Frankfurter, J.) (separate opinion) (state courts may not protect federal constitutional rights), with Stone v. Powell, 428 U.S. 465, 493-94 n.35 (1976) (disagreeing with this fear).

Mincey v. Arizona, 98 S. Ct. 2408 (1978), illustrates the disturbing potential of Stone. There, on direct appeal the Court reversed the Arizona Supreme Court's application of a homicide scene exception to the fourth amendment's exclusionary rule. In a pre-Mincey case, Sample v. Eyman, 469 F.2d 819 (9th Cir. 1972), a federal habeas court had ruled that exception unconstitutional. Nonetheless, following Slone, the Arizona Supreme Court reapplied the exception, apparently on the ground that the earlier decision by the federal habeas court was no longer controlling. Mincey v. Arizona, 98 S. Ct. 2408, 2419 (1978) (Marshall, J., concurring). Mincey suggests that Stone may increase the Supreme Court's workload if the Court must now accept more direct appeals to correct state court decisions which before Stone could have been left to the habeas courts to correct, and that Stone's assumption that state courts will fairly enforce federal constitutional rights is questionable.

264. Certainly no judge would ever admit, if asked, that he or she had denied a claim because of community pressure to convict, even if aware that the denial was unreviewable by a federal habeas court.

265. A state defendant's argument that denying him or her federal habeas review while giving that review to a defendant convicted of a federal crime violated the equal protection clause would probably not succeed. Cf. Ross v. Moffitt, 417 U.S. 600 (1974) (no equal protection violation in refusing to appoint counsel for indigent who petitions state or United States Supreme Court for review).

266. See generally Cover \& Aleinikoff, supra note 141. 
If the Supreme Court had decided to limit Brown rather than Fay, it would probably not have been blocked by either constitutional or legislative barriers. In Estelle, Francis, Sykes, and Stone, the Court obviously did not believe that the supremacy clause entitled the defendant to review by a federal court of his federal constitutional rights. ${ }^{267}$ And if Congress' implicit approval of Brown and Fay in its 1966 amendment to 28 U.S.C. $\S 2254^{268}$ did not stop the Francis/Sykes Court from arrogating the power to decide when federal courts should exercise federal jurisdiction in the absence of a defense objection, neither would section 2254 stop the Court from choosing not to follow Brozen. ${ }^{269}$

But limiting Brown might well have underscored, rather than solved, the vexing problems of federal habeas review faced by a Court anxious to promote comity, federalism, and finality over the need for a federal forum for constitutional claims. And as the next part shows, the Burger Court, in seeking an abrupt solution to these problems, may have created a new and unforeseen problem that it has not yet armed the federal habeas courts to solve.

\section{The SYKES Backlash: OUTFlanking "CaUSe and PREJUDICE" BY ATTACKING ATTORNEY INCOMPETENCE}

The ultimate ironic consequence of the cause and prejudice test is that by severely restricting access to federal habeas review for defendants whose counsel failed to make a timely claim, the Court has invited defendants to transform their constitutional claims into attacks

267. In none of the decisions did the Court even discuss the relevancy of the Constitution to its decisions. The Supreme Court may believe that no procedural due process problem exists if at least one court decides the merits of the constitutional issue. Cf. Huffman v. Pursue, Ltd., 420 U.S. 592, 606 \& n.18 (1975) (raising issue, without deciding, whether state litigant whose movie theater was closed pursuant to state nuisance law has right to federal court determination of federal constitutional issues). But see Tushnet, supra note 102, at 493-94 (arguing that supremacy clause and Habeas Corpus Act of 1867 constitutionally required review by federal court of constitutional issues). Other proposals that would affect Brown and Fay by creating a new federal appellate court to review habeas petitions or by restructuring the present federal appellate courts appear to assume that federal review of some sort is either constitutionally or statutorily required. See P. CARRINGTON, D. MEADOR \& M. ROSENBERG, JUSTICE ON APPEAL 114-20 (1976); Friendly, supra note 142, at 634-35; Haynsworth, supra note 14, at 604-07.

268. 28 U.S.C. § 2254 (1970); see Stone v. Powell, 428 U.S. 465, 528-29 (1976) (Brennan, J., dissenting).

269. In amending $\S 2254$, Congress did not explicitly enact the holdings of $F_{a y}$ and Townsend $v$. Sain, but instead indicated how the federal habeas courts should treat a determination on the merits by a state court. See 28 U.S.C. § 2254(d) (1970). This does not mean that the constitutional or statutory questions are as easily dismissed as the Court apparently thought. But if the Court could ignore those questions in Francis and Sykes, it could have done the same in limiting Brown. 
on their counsel's competence. The Court may therefore have subjected the federal habeas courts to an increased workload from both the new attacks on attorney incompetence and the need for a sharper definition of the attorney's responsibility in preserving federal claims. Though this strategy may create serious tensions in the attorney-client relationship, it may be the only resort for defendants whose path to federal habeas review has been blocked by Sykes.

\section{A. Attacking Counsel: The Only Open Road}

The Supreme Court has long recognized that legal representation is essential to the criminal defendant, ${ }^{270}$ and has interpreted the Constitution to give counsel to defendants in almost every situation. ${ }^{271}$ The individual's decision to forego counsel must meet the exacting waiver test of Johnson $v$. Zerbst. ${ }^{272}$ The waiver is effective only if the defendant understands the significance of the decision, and any doubt about that understanding must be resolved in the defendant's favor. ${ }^{273}$

If counsel is necessary to protect the defendant, Estelle, Francis, and Sykes demonstrate that counsel is also the only protection the defendant usually receives. The adversary process pits the counseled defendant against the government. The trial court need not intercede to protect the defendant, ${ }^{274}$ even if counsel has not challenged some governmental conduct presumed to be prejudicial, so long as that failure to object might stem from a tactical judgment. ${ }^{275}$

270. See Powell v. Alabama, 287 U.S. 45 (1932).

271. See Argersinger v. Hamlin, 407 U.S. 25 (1972) (any prosecution where jail sentence possible); Gideon v. Wainwright, 372 U.S. 335 (1963) (felonies).

272. 304 U.S. 458 (1938).

273. See Brewer v. Williams, 430 U.S. 387 (1977); Faretta v. California, 422 U.S. 806 (1975).

274. See Wainwright v. Sykes, 433 U.S. 72, 91 (1977); Estelle v. Williams, 425 U.S. 501, 512 (1976).

275. In Estelle, for example, the trial court was not obligated to intercede even though the court of appeals had decided several years earlier that the defendant's appearance in jail clothes was inherently prejudicial. Cf. United States v. Williams, 544 F.2d 1215, 1218 (4th Cir. 1976) (no duty to mention statutory right to defendant even if refusal to grant right upon request creates irrebuttable presumption of harm).

Judges may, however, be understandably uncertain about their responsibility. The judge may be required to intercede if he or she recognizes the error, see Sincox v. United States, 571 F.2d 876 (5th Cir. 1978) (during polling of jurors, juror said he had "reasonable doubt" about guilty verdict), or if counsel says something, however vague and inarticulate, that sounds like a constitutional objection, of. Taylor v. Kentucky, 98 S. Gt. 1930 (1978) (defense counsel's requested instructions should have alerted judge to constitutional issues). 
Only the defendant's objection can force the government to establish the constitutional foundation to admit certain evidence; the trial court need not, sua sponte, determine whether the government's conduct meets constitutional standards. ${ }^{276}$ The trial court need not ask counsel whether he has in fact decided not to object or why he made that decision, no matter how easily it could make that inquiry. ${ }^{277}$ Nor must the prosecutor oversee the defense attorney to ensure that the latter adequately represents the client. ${ }^{278}$

By failing to object, then, defense counsel can bar his client from review by any court of the merits of a constitutional issue. ${ }^{279}$ Apparently, according to Estelle, Francis, and Sykes, counsel need not consult with the client or adequately research either the law or the facts before making that decision. Given the attorney's power, and the catastrophic consequences of ineffective representation, ${ }^{280}$ the attorney's conduct itself is likely to become an issue on collateral attack. ${ }^{281}$ Estelle, Francis, and Sykes do not discuss whether the defendant can

276. In Sykes, for example, both the district court and court of appeals, see Wainwright v. Sykes, 528 F.2d 522, 525 (5th Cir. 1976), thought that Jackson v. Denno, 378 U.S. 368 (1964), required that the trial court conduct a hearing to determine whether the defendant's confession was constitutionally admissible, even if counsel did not object. The Supreme Court disagreed, holding that Jackson established the procedure to determine that issue, but did not guarantee a hearing to the defendant without an objection. Wainwright v. Sykes, 433 U.S. 72, 86 (1977).

In contrast, to protect the defendant's right to counsel, the trial court may be required to warn the defendant of potential conflicts of interest in multiple representation cases. $C f$. Holloway v. Arkansas, $98 \mathrm{~S}$. Ct. 1173, 1178. (1978) (reserving question whether trial court must sua sponte warn defendants of potential conflicts). Compare United States v. Lawriw, 568 F.2d 98 (8th Cir. 1977), cert. denied, 98 S. Ct. 1607 (1978) (trial court must advise multiple defendants of potential danger in representation by single attorney and of right to own counsel), with Foxworth v. Wainwright, 516 F.2d 1072 (5th Cir. 1975) (obligation to anticipate reasonably foreseeable conflicts of interest at time of counsel's appointment, but no obligation to warn co-defendants of potential disadvantages of joint representation).

277. The trial court could conduct a sidebar conference during the trial or a pretrial conference, or could ask the attorney to prepare a checklist of his or her decisions. See Tague, The Altempt to Improve Criminal Defense Representation, 15 AM. CRIM. L. REV. 109, 161-65 (1977).

278. The "plain error" doctrine provides some check on the government's abuse of power. See 8B MOORE, supra note 105, ๆ 52.02[2] \& n.10. Defining "actual prejudice" more restrictively than "plain error" would eliminate this check. The Supreme Court is not quick to impose guidelines on prosecutorial conduct. Cf. Bordenkircher v. Hayes, 434 U.S. 357, $365 \&$ n.9 (1978) (noting suggested guidelines on prosecutor's conduct but holding that due process was not violated where prosecutor increased charges when defendant refused initial plea offer).

279. While Stone was not pitched as a constitutional decision and does not explicitly require that the defendant's claim be litigated in any court, the thrust of Stone appears to be that due process guarantees the defendant the opportunity to litigate his claim in either state or federal court. See note 267 supra.

280. See note 129 supra and accompanying text.

281. Cf. United States ex rel. Smith v. DiBella, 314 F. Supp. 446 (D. Conn. 1970) (state 
reframe what would have been an attack on the government's conduct into an attack on the attorney's representation. In each case, the Court was spared that analysis by appellate counsel's decision not to press that claim. ${ }^{282}$

But unlike Fay, Estelle, Francis, and Sykes pressure the defendant to attack counsel's effectiveness rather than, or in addition to, the government's conduct that counsel did not challenge. ${ }^{283}$ Concurring in Sykes, Justice White all but invited the defendant to attack counsel's competency for failing to object, ${ }^{284}$ an attack that some federal habeas courts have also implied that the defendant must make in order to get collateral review. ${ }^{285}$

To permit the defendant to attack counsel's conduct on collateral review is justified by the reasons for habeas review. The habeas court could not infer that the defendant waived a challenge to counsel's ineffectiveness by not objecting at trial, and counsel could not himself waive an attack on his own representation. Moreover, evidence of ineffectiveness is usually outside the record on direct ap-

procedural rule holding that failure to object worked automatic forfeiture was equivalent to state determination that that failure was ineffective representation).

282. In Francis, for example, appellate counsel decided for "political" reasons not to attack the trial attorney as ineffective, perhaps because the trial attorney was a noted minority civil rights lawyer. Interview with appellate counsel (Mar. 28, 1978). In Sykes, trial counsel represented the defendant through the state appellate process, and obviously did not challenge his own effectiveness. Sykes' appointed attorney on federal habeas attack chose not to raise the issue, because he wanted to avoid a remand to the state courts to exhaust the issue. Sykes therefore stipulated to his trial counsel's effectiveness, a stipulation that appellate counsel later regretted. Interview with appellate counsel (Mar. 15, 1978). In Estelle, appellate counsel elected not to press the claim in the Supreme Court as an alternative ground to affirm the Fifth Circuit's decision. Interview with appellate counsel (Mar. 18, 1977). The federal district court in that case had decided that trial counsel had not been ineffective in allowing his client to wear jail clothes in court. Williams v. Beto, 364 F. Supp. 335, 339 (S.D. Tex. 1973).

283. Because Fay permitted habeas review so long as the defendant himself did not bypass the objection, the defendant did not need to attack counsel's effectiveness. Although Henvy v. Mississippi may have barred federal habeas where counsel bypassed the objection, Henry apparently did not result in an increase in ineffectiveness claims. See Shapiro, supra note 141 , at $348-49$.

284. Wainwright v. Sykes, 433 U.S. 72, 99 (1977) (White, J., concurring).

285. Many opinions note that the defendant did not challenge the attorney's competency in failing to object. See Gates v. Henderson, 568 F.2d 830, 840 (2d Cir. 1977) (en banc); Mildwoff v. Cunningham, 432 F. Supp. 814, 821 (S.D.N.Y. 1977) (absent claim of incompetency, defendant bound by counsel's decisions); United States ex rel. Brown v. Warden, $417 \mathrm{~F}$. Supp. 970, 974 (N.D. Ill. 1976) (without charge of incompetency, court unwilling to make "cynical assumption" necessary to distrust counsel's conclusion that issue frivolous); if. Crowell v. Zahradnick, 571 F.2d 1257, 1259 n.2 (4th Cir. 1977) (suggesting defendant could turn counsel's failure to object into charge of ineffective representation). 
peal and can be developed and presented only on collateral attack. ${ }^{286}$ Further, the Supreme Court has always assumed that counsel could deliberately bypass raising a federal claim in the state courts only if his or her decision was competent. ${ }^{287}$ And several courts have held that counsel's failure to object constitutes ineffective representation. ${ }^{288}$

\section{B. The Defendant's New Strategy}

By alleging ineffective representation in his petition, the defendant may be able to outflank the Court's attempt to limit habeas review even though the basis of ineffectiveness is simply counsel's failure to object. In Cooper v. Fitzharris, ${ }^{289}$ for example, on federal habeas, petitioner challenged his counsel's competency for her failure to move to suppress the fruits of a search at his state court trial. The federal district court denied the petition, concluding that the admission of the items seized was harmless error, whether or not the search was constitutional. ${ }^{290}$ A panel of the Ninth Circuit Court of Appeals reversed, and, in remanding for the district court to decide whether counsel had been ineffective, stated that the district court could not ignore the issue of ineffectiveness by determining the merits of the motion that counsel had failed to make. ${ }^{291}$ The panel held that a

286. On direct appeal an appellate court will usually consider only those issues presented by the trial record and will not accept any additional evidence. See United States v. Huntley, 535 F.2d 1400 (5th Cir. 1976). This limitation may explain the clever approach taken by a panel of the District of Columbia Circuit in permitting an attack on counsel's effectiveness by a motion for new trial, which permits augmentation of the record on direct appeal. See United States v. DeCoster, 487 F.2d 1197 (D.C. Cir. 1973), rehearing No. 721283 (D.C. Cir., filed Oct. 19, 1976), vacated, Mar. 17, 1977 (en banc) (decision pending).

287. See Fay v. Noia, 372 U.S. 391, 439 (1963); of. Tollett v. Henderson, 411 U.S. 258 (1973) (attack on guilty plea barred unless counsel's pre-plea advice is outside "range of competence demanded of attorneys in criminal cases').

288. See Saltys v. Adams, 465 F.2d 1023 (2d Cir. 1972) (failure to object to highly questionable identification procedure constitutes ineffective representation); $f$. Chambers v. Maroney, 399 U.S. 42, 59 (1970) (Harlan, J., dissenting in part) (issue of counsel's effectiveness in regard to failure to raise fourth amendment claim not moot even if failure to grant claim was harmless error). Other such decisions have involved direct appeals. See United States v. Easter, 539 F.2d 663 (8th Cir. 1976) (counsel's failure to object to police search constituted ineffective representation); People v. Ibarra, 40 Cal. 2d 460, 386 P.2d 487, 34 Cal. Rptr. 863 (1963) (failure to object to introduction of contraband seized in questionable search ineffective representation). But see LiPuma v. Commissioner, Dep't of Corrections, 560 F.2d 84 (2d Cir.), cert. denied, 434 U.S. 861 (1977) (strategic decision not to file suppression motion not ineffective representation); United States v. Elksnis, 528 F.2d 236 (9th Cir. 1975) (failure to object to jury instruction not ineffective representation).

289. 551 F.2d 1162 (9th Gir. 1977), rehearing en bane ordered, Sept. 22, 1977 (decision pending).

290. Id. at 1163-64.

291. Id. at 1164-66. The district court found that the failures of the trial counsel did 
finding of ineffective representation required automatic reversal even if counsel's ineffectiveness had not prejudiced the defendant. ${ }^{292} \mathrm{Au}-$ tomatic reversal was necessary as a prophylactic remedy to protect the sixth amendment right to counsel. ${ }^{293}$ The panel suggested that representation was sufficient if counsel "is prepared and conducts the defense with reasonable knowledge and skill with an exercise of knowledgeable choices of trial tactics."294 Because Cooper's attorney recognized that the admissibility of the seized evidence presented several constitutional issues, but did not research those issues or decide not to object for any tactical reason, ${ }^{295}$ her representation, based on the panel's test, was probably ineffective. ${ }^{296}$

If other courts follow the approach of the panel in Cooper, federal habeas petitioners will not only receive more frequent review by arguing ineffective representation, but will also have a better chance of obtaining relief than if they only sought habeas review of the merits of the issue that counsel did not raise. Cooper thus undercuts the Court's attempt in Estelle, Francis, and Sykes to limit the availability of both habeas review and relief. The admissions by Cooper's attorney at the habeas hearing would probably not constitute "cause" to excuse the failure to object, and Cooper had obviously not established that the failure to object had "prejudiced" him.

\section{The Court's New Task}

As a result of this new defense strategy, the Supreme Court will have to explain when the failure to object constitutes ineffective rep-

not "rise to the level of making the trial a sham or mockery of justice," but the court of appeals held that this was the wrong standard for testing ineffectiveness. Id.

292. Id. at 1165 .

293. $I d$.

294. Id. at 1166 .

295. Id. at 1163 n.1.

296. The panel remanded the case to the district court to determine the ineffectiveness issue. Id. at 1166 .

There remains a question of the type of relief petitioner receives if counsel's representation is found ineffective. The federal habeas court may not reverse the conviction for a new trial, but will instead remand to the state court to rule on the issue counsel did not raise. If the state court rules against the petitioner-and the pressure will be great to do just that-it will obviously not reverse the conviction. If the state court rules for petitioner, it may still not reverse if it applies the harmless error test. Either decision by the state court may be open to relitigation on federal habeas, absent the application of Stone. See, e.g., United States ex rel. Rosner v. Commissioner, Dep't of Corrections, 421 F. Supp. 781 (S.D.N.Y. 1976), rev'd sub nom. LiPuma v. Commissioner, Dep't of Corrections, 560 F.2d 84 (2d Cir.), cert. denied, 434 U.S. 861 (1977) (where all issues raised on appeal heard in state court, Stone precludes federal habeas corpus relief). 
resentation. The Court has never clearly defined the standard for ineffective representation. ${ }^{297}$ Forced to do so now, the Court will probably adopt the standard established in McMann v. Richardson ${ }^{298}$ to test whether to overturn the guilty plea of a defendant who seeks post-conviction review of an issue that counsel did not raise before the defendant pleaded guilty. MoMann held that the post-conviction court should not review the merits of that issue, but should instead examine whether counsel's erroneous advice about that issue had made his client's guilty plea unintelligent. The post-conviction court should grant relief only if counsel's advice fell outside "the range of competence demanded of attorneys in criminal cases."299

But even assuming that McMann states the test for ineffective representation, it does not explain how the federal habeas courts should apply that test. Courts have been divided in their interpretation of McMann. Many have replaced the "farce" standard with a test that asks whether the attorney's performance was reasonable. ${ }^{300}$ Yet they

297. Several Justices have urged the Court to clarify the constitutional standard for effective representation. See Maryland v. Marzullo, 98 S. Ct. 1885 (1978) (White \& Rehnquist, JJ., dissenting from denial of certiorari where court of appeals had applied "within range of competency" test to reverse district court); Francis v. Henderson, 425 U.S. 536, 553 n.4 (1976) (Brennan, J., dissenting). The Court has twice failed to explain the relationship between the failure to object and ineffective representation. In Browder v. Director, Dep't of Corrections, 434 U.S. 257 (1978), the district court, on collateral attack, reversed the defendant's conviction, deciding the merits of a fourth amendment claim that petitioner had not raised at trial and that the state appellate courts had not decided. On certiorari, following the court of appeals' reversal of the district court's decision, petitioner-defendant suggested that his attorney's incompetency deprived him of the opportunity for "full and fair litigation" of his fourth amendment claim. Petitioner's Brief in the Supreme Court of the United States at 46. The Supreme Court did not discuss whether that failure amounted to ineffectiveness, or whether ineffectiveness permitted federal habeas review of the fourth amendment issue, but reinstated the district court's decision because the state had not filed a timely notice of appeal from the district court's decision.

In Chambers v. Maroney, 399 U.S. 42 (1970), where counsel had not made a fourth amendment motion to suppress, the Court ducked the ineffectiveness issue because the court of appeals had found the admission of the unchallenged evidence harmless error. Id at 54 . Dissenting on this point, Justice Harlan thought that the harmlessness of counsel's failure did not moot the issue of whether his failure to object was ineffective representation. Id. at 59 (Harlan, J., dissenting). Unfortunately, Justice Harlan did not explain the relationship between the merits of the issue counsel failed to raise and counsel's effectiveness.

298. 397 U.S. 759 (1970).

299. Id. at 770-71. MCMann suggests that the habeas court must consider the significance of the particular failure to object rather than whether counsel's overall performance, apart from the failure to object, was competent. But see Williams v. Beto, 364 F. Supp. 335, 339 (S.D. Tex. 1973) (counsel's overall performance competent even if he failed to challenge defendant's appearance in jail clothes), affd on other grounds sub nom. Estelle v. Williams, 425 U.S. 501 (1976).

300. See, e.g., Beasley v. United States, 491 F.2d 687 (6th Cir. 1974); Moore v. United States, 432 F.2d 730 (3d Cir. 1970); see Note, Ineffective Assistance of Counsel: Who Bears the Burden of Proof?, 29 Baylor L. REv. 29, 32-35 (1977) (listing cases and commentators). 
have not settled two questions of vital importance to the Burger Court's attempt to limit habeas relief: First, what part the harm caused by counsel's failure plays in deciding whether to reverse, and, second, assuming that the question of harm is relevant, whether the defendant carries the burden of proving how his counsel's failure prejudiced him, or whether the government must instead prove that counsel's error was harmless. ${ }^{301}$ The answers to these questions will obviously affect the implementation of Francis, Sykes, and Estelle. If a court chooses, as the panel appeared to do in Cooper, to reverse automatically - without a finding of actual prejudice-once it finds that counsel's performance did not meet the McMann standard, that choice will make it easier for the defendant to obtain habeas relief by arguing ineffective representation than by asking for collateral review of the merits of the constitutional issue that counsel did not raise.

To protect its work in Estelle, Francis, and Sykes, then, the Supreme Court has two options. First, it could simply eliminate ineffective representation as an issue on habeas review if counsel failed to raise an issue that itself would be barred from habeas review because it is not guilt-related. ${ }^{302}$ Were the Court to adopt this approach, it obviously would have to identify those issues that are not guilt-related, the violation of which would never contribute to the conviction of an innocent defendant. Because identifying those issues would be difficult, ${ }^{303}$ the Court is more likely to add a requirement to the MCMann test that the defendant show that his counsel's failure

301. Compare LiPuma v. Commissioner, Dep't of Corrections, 560 F.2d 84, 91 (2d Gir.), cerl. denied, 434 U.S. 861 (1977) (defendant must prove actual prejudice; holding, however, may reflect the Second Circuit's retention of generally rejected "farce" standard), and Beasley v. United States, 491 F.2d 687 (6th Cir. 1974) (ineffectiveness where counsel deprived defendant of substantial defense; implying such finding required proof of prejudice), with United States v. DeCoster, 487 F.2d 1197, 1204 (D.C. Cir. 1973), rehearing No. 72-1283 (D.C. Cir., Oct. 19, 1976), vacaled, Mar. 17, 1977 (en banc) (decision pending).

302. A recent Senate bill anticipated the problem of petitioner's reconstructing his habeas petition as an attack on counsel's competency for having failed to object, and would have barred such attack whenever the unmade objection did not go to the reliability of the verdict. S. 567, 93d Cong., 1st Sess. § 2(a) (1973); see H.R. 13,722, 92d Cong., 2d Sess. (1972); Kleindienst Letter, supra note 146, at 2224. See also LiPuma v. Commissioner, Dep't of Corrections, 560 F.2d 84, 93-94 n.6 (2d Cir.), cert. denied, 434 U.S. 861 (1977) (charge of ineffectiveness barred if based on fourth amendment claim which defendant had an opportunity to litigate in state court).

303. Any constitutional issue that affects the evidence considered by the jury could contribute to a factually erroneous verdict. On the other hand, "technical" defenses that do not control the evidence introduced at the trial are not related to factual guilt. See notes 152-75 supra and accompanying text. 
actually prejudiced him. ${ }^{304}$ However, to add such a requirement does seem inconsistent with McMann. A defendant who pleads guilty, after all, admits his factual guilt. ${ }^{305}$ To warrant overturning the plea, McMann does not require the defendant to prove that he was factually innocent in addition to proving that his plea was not intelligent. Moreover, to add that requirement would eliminate reversal as a prophylactic remedy to force counsel to protect his client. $^{306}$ Because Estelle, Francis, and Sykes expect that the attorney

304. The Court must also define "actual prejudice" as "factual innocence" to eliminate the confusion in the courts of appeals' definitions of that term. Some courts have required proof that counsel's ineffectiveness deprived the defendant of a guilt-related defense, see Beasley v. United States, 491 F.2d 687 (6th Cir. 1974) (reversal where counsel's ineffectiveness stripped defendant of substantial defenses), but others have held that counsel's failure to move to suppress evidence, the possession of which constituted a crime, deprived the defendant of a crucial defense, see United States v. Easter, 539 F.2d 663 (8th Cir. 1976). Easter appears inconsistent with Stone, Francis, and Sykes, even if the suppression motion was the defendant's only attack, because the non-objected-to evidence was obviously reliable, and the failure to object did not endanger the accuracy of the verdict.

305. The trial judge must determine whether a factual basis for the plea exists. FED. R. GRIM. P. 11(f). Of course, some defendants may admit factual guilt to get the advantage of the plea bargain even if they are innocent. See North Carolina v. Alford, 400 U.S. 25 (1970) (court can accept guilty plea of defendant who refuses to admit factual guilt if satisfied that strong evidence of guilt exists). McMann would appear to bar inquiry into the factual basis of an intelligent, voluntary plea.

306. On the other hand, an added requirement of prejudice is probably not inconsistent with the Court's decisions in Holloway v. Arkansas, 98 S. Ct. 1173 (1978), or Glasser v. United States, 315 U.S. 60 (1942), in which the Court reversed automatically-apparently without a showing of prejudice-where the trial court improperly required joint representation despite defense objections of conflict of interest. In Glasser, the trial court had refused to honor the defendant's request for his own attorney, and had instead appointed for him an attorney who had also represented a co-defendant. Because the trial court had thereby actively interfered with the defense, the Supreme Court refused to make "nice calculations as to the amount of prejudice arising from [the] denial" of the defendant's request for his own attorney. Id. at 76. Glasser is thus better understood as based on the denial of one's right to a personal attorney than on denial of effective representation. Cf. Holloway v. Arkansas, $98 \mathrm{~S}$. Ct. 1173, 1178-79 (1978) (trial court's refusal to appoint separate counsel "deprived petitioners of the guarantee of 'assistance of counsel' "). But the Glasser Court's comment that the evidence against the defendant was not strong and was largely circumstantial, 315 U.S. at 67, suggests that it was also applying something like a harmless error test and would ordinarily require proof of prejudice. And the Court's denial of relief to Glasser's co-defendant, who had not shown how he had been prejudiced by the error affecting Glasser, has been interpreted to mean that Glasser requires proof of prejudice, see Geer, Representation of Mulliple Criminal Defendants: Conficts of Interest and the Professional Responsibility of the Defense Altomey, 62 MiNN. L. REv. 119, 122-25 (1978), even though that denial is probably better understood by analogy to the standing requirement for the exclusionary rule. Ultimately, Glasser's constitutional test is so unclear that the decision will not prevent the Supreme Court from adopting the prejudice requirement for claims of ineffective counsel. Moreover, Holloway and Glasser involved direct appeals. Even if they are properly interpreted as excusing proof of prejudice, the Court might not follow them when the claim of ineffective counsel arises in habeas. petitions.

The Cooper panel may therefore have improperly relied on at least Glasser to free the 
alone will protect the defendant, the attorney's representation should be closely examined, and courts should be willing to apply a prophylactic remedy. ${ }^{307}$

Yet even if the Burger Court can protect the Estelle, Francis, and Sykes barriers to habeas relief by adding the requirement of prejudice to the test for effective representation, the Court will not have relieved the habeas court of any work. The habeas court must still develop the facts relevant to the motion that counsel did not make, as it had to do in following Fay. If the habeas court decides that the issue lacked merit, or that the failure to raise the issue did not actually prejudice the defendant, the court could deny the ineffectiveness challenge without determining why counsel did not object. ${ }^{308}$ But if the habeas court cannot deny the petition on those grounds, it must

defendant from the obligation to prove that his counsel's failure to object had prejudiced him. Cooper also relied inaccurately on Geders v. United States, 425 U.S. 80 (1976) (trial court had refused to permit counsel to speak with client during recess in latter's testimony), and Herring v. New York, 422 U.S. 853 (1975) (trial court refused to hear final argument by counsel during bench trial), both cases where the trial courts had interfered with counsel's ability to represent his client. Holloway, Glasser, Geders, and Herring all appear to suggest that the trial court cannot intercede to interfere with the defense, though it need not intervene to protect the defendant from counsel.

307. The problem is deciding what the test for ineffective representation should be designed to do. If designed as a prophylactic to help improve the performance of attorneys, the defendant should not need to prove prejudice. Cf. Ohralik v. Ohio State Bar Ass'n, $98 \mathrm{~S}$. Ct. 1912, 1923-24 (1978) (discipline of attorney for breaching antisolicitation statute approved as prophylactic remedy even where client suffered no harm). If designed to protect only the factually innocent defendant, the defendant must prove prejudice. If the latter is the role played by the right to effective representation, some other method to discipline attorneys is essential, given the questionable performance of so many of them. See, e.g., Watkins v. Green, 548 F.2d 1143 (5th Cir. 1977) (in violation of state timing provisions, counsel failed to object to grand and petit juries until day before trial; state courts and federal habeas courts enforced state law and refused to decide merits; counsel had made same timing mistake in earlier case where his objection, made on day before trial, had also been barred on appeal). In his most recent caustic evaluation of the performance of attorneys, Chief Justice Burger suggested that $50 \%$ of the trial lawyers are unqualified, an estimate based on questionable evidence (the Chief Justice averaged other judicial estimates of from 25 to $75 \%$ without apparent regard for the numbers of attorneys practicing before the judges who gave the estimates), but nevertheless illustrating the Chief Justice's concern. The Washington Post, Feb. 13, 1978, at A4, col. 1-2.

308. See United States ex rel. Chambers v. Maroney, 408 F.2d 1186 (3d Cir. 1969) (failure to move to suppress evidence harmless error; no need to decide ineffective representation claim), affd, 399 U.S. 42 (1970); Spencer v. Cundiff, 413 F. Supp. 1246 (W.D. Va. 1976) (counsel's failure to properly raise defendant's speedy trial motion not ineffective representation, since defendant not prejudiced by delay before trial). This approach appears fundamentally different from the panel's decision in Cooper, which required the habeas court to treat the question of counsel's effectiveness separately from the merits of the issue that counsel had failed to raise. Cooper suggested that habeas relief could be granted whenever the attorney should have objected, even if that failure did not prejudice the defendant. Cooper v. Fitzharris, 551 F.2d 1162, 1165 (9th Cir. 1977), rehearing en banc ordered, Sept. 22, 1977 (decision 
then determine why counsel did not object-the same determination that it had to make under Fay in deciding deliberate bypass-in order to decide whether counsel's failure to object was a reasonable decision.

Another disadvantage of pressuring the defendant to attack counsel's competency-assuming that that attack reopens access to federal habeas review by circumventing the Sykes rule-is the effect of such a tactic on the attorney-client relationship. To convert counsel's failure to object into a challenge to counsel's effectiveness may create grave tension between counsel and client. In future habeas proceedings, the defendant will be pitted against his or her own attorney; the latter's representation will always be exposed to attack. Of course, some attorneys may respond positively by preparing their cases more carefully and discussing every constitutional issue with the defendant to gain agreement on any decision not to object, ${ }^{309}$ or by documenting the reasons why they decided not to object. But many other attorneys may respond by refusing court appointments, or by making every possible objection at trial-thereby increasing the trial court's workload—or by treating the client as a potential adversary who therefore should not be consulted on trial strategy.

By cutting off access to federal habeas review of specific constitutional claims, the Court in Estelle, Francis, and Sykes may have forced defendants into this alternate strategy - a strategy that may have the primary effect of increasing the federal court workload that those decisions were designed to reduce. As a result, one must question whether the advantages that the Supreme Court sought to achieve in Estelle, Francis, and Sykes outweigh the problems these decisions may create.

pending). This is an approach the Burger Court must reject in order to avoid undercutting Estelle, Francis, and Sykes.

If the Burger Court does not add the prejudice test, the job of the habeas court will be more difficult in deciding counsel's effectiveness than in deciding, under Fay, the merits of the issue that counsel did not raise. For, as in Cooper, the habeas court must then determine why counsel did not object and whether counsel's failure was unreasonable, regardless of whether an objection should have been granted.

Interestingly, to force the habeas court to decide the merits of the issue counsel failed to raise would make the treatment of ineffective representation claims the same whether brought by a habeas petitioner or by a defendant who sues his attorney for malpractice. See Martin v. Hall, 20 Cal. App. 3d 414, 97 Cal. Rptr. 730 (2d Dist. 1971) (in malpractice suit, merits of issue counsel did not raise is legal issue for trial court rather than for jury to decide).

309. The Court could have achieved this salutory consequence by further defining Fay and Henry to require the attorney to consult with his client about every constitutional motion to suppress, and to give counsel both the power to decide whether to object after that consultation and the power to make every decision during trial which he could not reasonably have anticipated and which required an instant decision. 


\section{Conclusion}

By misinterpreting the reasons why defense attorneys fail to object, the Supreme Court has undervalued the importance of habeas review for the defendant. No one can deny the unfairness of forcing the government to suffer reversal of a conviction because defense counsel, over whom the government has little control, has erred. Nor can one deny the need to free the federal habeas courts from the difficult tasks of deciding why counsel did not object and of hypothesizing about the possible prejudice to the defendant caused by counsel's failure. But it is more unfair for the defendant to suffer because of his attorney's failure: Defendants need habeas review to protect themselves from ineffective representation.

Ironically, the decisions in Estelle, Francis, and Sykes may aggravate the very problems in judicial administration that the Court hoped to solve. Because defendants may be able to gain access to federal habeas review by attacking the competency of counsel, the new doctrines will not achieve and may even further frustrate the Court's avowed goals of finality, federalism, and the administration of justice. The Court should recognize that the three decisions are misdirected, and then restore Fay. But if the Court does not-and the language of the decisions surely suggests that it will not-the Court should consider whether restricting Brown, as suggested in this article, rather than restricting $F a y$ is the better approach. Restricting Brown as suggested would at least ensure that the defendant received review by some court of the constitutional issues presented by his case. Whatever the Court chooses to do, however, if it conceives its role as finding a just and rational solution to the vexing problems of federal habeas review, it now must recognize that its work has just begun. 
